\title{
The Andean Paepalanthus pilosus complex (Eriocaulaceae): a revision with three new taxa
}

\author{
Nancy Hensold' \\ I Keller Science Action Center, The Field Museum of Natural History, 1400 S. Lakeshore Drive, Chicago, IL \\ 60605-2496, USA \\ Corresponding author: Nancy Hensold (nhensold@fieldmuseum.org)
}

Academic editor: R.P. Oliveira | Received 15 October 2015 | Accepted 25 May 2016 | Published 13 June 2016

Citation: Hensold N (2016) The Andean Paepalanthus pilosus complex (Eriocaulaceae): a revision with three new taxa. PhytoKeys 64: 1-57. doi: 10.3897/phytokeys.64.6864

\begin{abstract}
A herbarium-based revision is provided for Paepalanthus pilosus and allies, five commonly confused species of cushion plants native to Andean paramo. These are placed in the recircumscribed Paepalanthus subsect. Cryptanthella Suess. The group includes $P$. pilosus, $P$. dendroides, and $P$. lodiculoides. An additional two species and one variety are newly described: Paepalanthus caryonauta, P. huancabambensis, and P. pilosus var. leoniae. The latter two are Peruvian endemics, while $P$. caryonauta is known from four countries, and has long been confused with other species. An additional, possibly undescribed taxon is noted from the Serrania de Perijá, Colombia. Five new synonyms and three lectotypes are proposed, and the common misapplication of some names is noted. Within the P. pilosus complex, species differences were found in timing of peduncle elongation, sex ratio, and leaf, perianth, diaspore and nectary morphology. Ecological differences are suggested by specimen data and a review of ecological literature. Descriptions, photographs and maps are provided for all species, as is a key to the groups of eriocaulaceous cushion plants from Andean South America.
\end{abstract}

\section{Keywords}

Andes, cushion plants, diaspores, leaf anatomy, nectaries, new species, paramo, taxonomy 


\section{Contents}

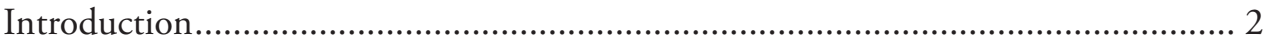

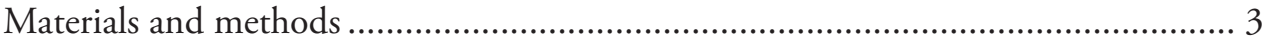

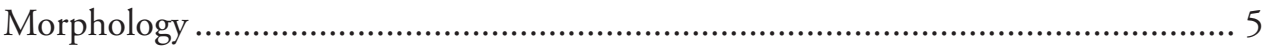

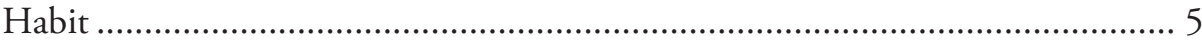

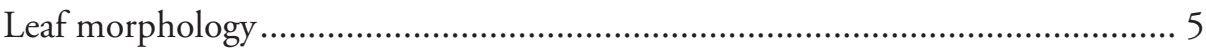

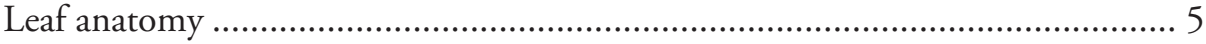

Timing of peduncle elongation ..................................................................... 7

Arrangement of staminate and pistillate flowers................................................ 8

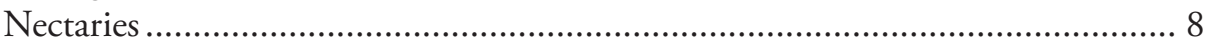

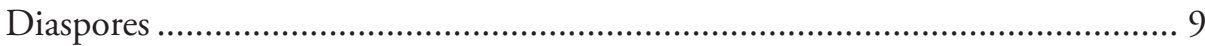

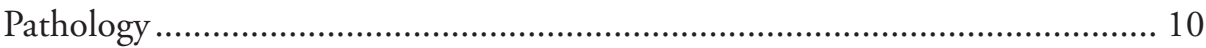

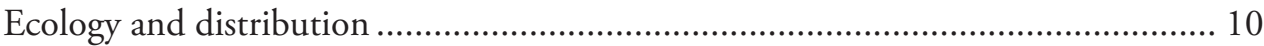

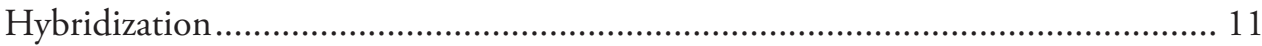

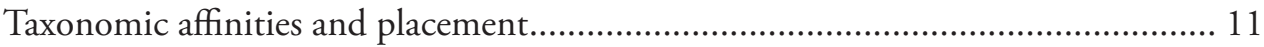

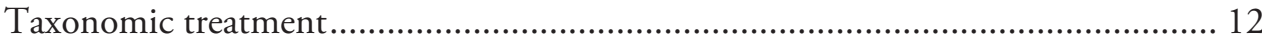

Key to major groups of Andean cushion plants in the Eriocaulaceae.................. 12

Key to the species of Paepalanthus subsect. Cryptanthella .................................. 13

Paepalanthus subsect. Cryptanthella Suess......................................................... 14

1. Paepalanthus caryonauta Hensold, sp. nov. ………................................ 15

2. Paepalanthus dendroides (Kunth in H.B.K.) Kunth ................................. 24

3. Paepalanthus huancabambensis Hensold, sp. nov. .................................... 30

4. Paepalanthus lodiculoides Moldenke....................................................... 33

5. Paepalanthus pilosus (Kunth in H.B.K.) Kunth...................................... 36

5a. Paepalanthus pilosus (Kunth in H.B.K.) Kunth var. pilosus ..................... 38

5b. Paepalanthus pilosus var. leoniae Hensold, var. nov. ................................. 47

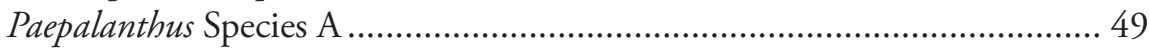

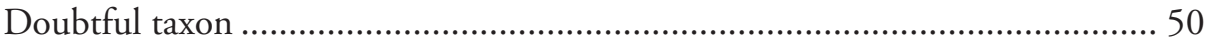

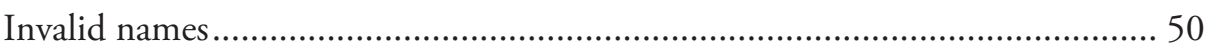

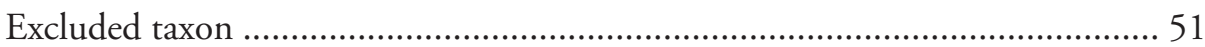

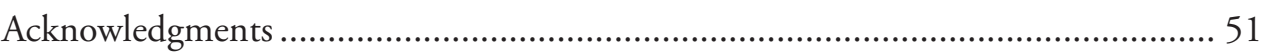

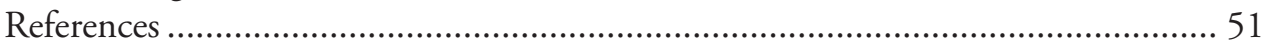

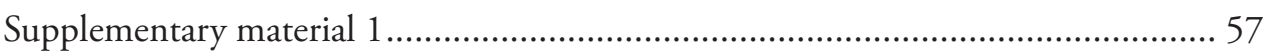

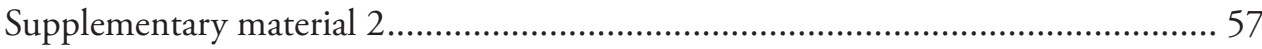

\section{Introduction}

The Eriocaulaceae (Liliopsida: Poales) are a family of 10 genera and about 1200 species, about 800 of which are Neotropical (The Plant List 2013; Giulietti et al. 2012). They usually occur on wet sunny sites with sandy or otherwise acidic soils, and are most diverse in the central highlands of Brazil and the Guiana Shield of Venezuela. 
In the Andes, diversity is relatively low. About 34 species, including 29 species of Paepalanthus Mart., are currently recorded from Andean montane forest and páramo (ca. 1800-4000 m). These occur from Bolivia northwards, with a few extending to the Talamanca range in Costa Rica. Most are endemic to this region. (Giulietti 2015; Hensold and Hammel 2003; Hensold 2008; Hensold 2014; León-Yanez and Hensold 1999; Brako and Hensold 1993; Tissot-Squalli 1997).

The Paepalanthus pilosus complex includes seven of the currently recognized Andean species: $P$. barkleyi Moldenke, $P$. dendroides (Kunth) Kunth, P. dennisii Moldenke, $P$. karstenii Ruhland, $P$. lodiculoides Moldenke, P. pilosus (Kunth) Kunth, and P. schultesii Moldenke. Members of this complex are characteristic elements of wet peaty sites in climatically humid páramo and subparamo from Costa Rica to Bolivia. All exhibit the cushion plant growth form, or "pulviniform" habit, found among diverse flowering plant families of high-elevation páramo (Luteyn 1999). The similar aspect of the plants, their reduced foliage and capitula, and the variable form of the cushions in response to environment, can make species recognition difficult, and indeed, misidentifications and misconceptions have been common in the taxonomic, floristic and ecological literature.

These species are also easy to confuse with other Andean cushion plant species, including Eriocaulon microcephalum Kunth and the three Andean taxa of Paepalanthus subsect. Dichocladus Ruhland ( $P$. dichotomus var. glabrescens Moldenke, $P$. ferreyrae Moldenke, and $P$. muscosus Körn.), but can be distinguished by floral and seed morphology and other microcharacters, as detailed below. Some of the 16 species of Paepalanthus subg. Platycaulon Mart. endemic to the Andes also proliferate from the base and have been described as cushion plants ("polsterformig"; Tissot-Squalli 1997), but these have larger leaves $5-18 \mathrm{~cm}$ long arranged in rosettes, and may be more precisely described as "cushion-rosettes" ( $c f$. Aubert et al. 2014a).

This study was originally focused on resolving taxonomy of the Peruvian members of the $P$. pilosus complex, but later expanded to a herbarium study of all Andean material at hand. While I attempted to describe all material available to me, including that of Colombia and Venezuela, a detailed study of North Andean material was outside the scope of this work. Both $P$. dendroides and $P$. pilosus exhibit more complex variation over their range than is found in Peru and Ecuador, and the descriptions may not entirely reflect populations of northern South America. Results from more intensive field or molecular studies may add much to our understanding.

\section{Materials and methods}

Specimens were examined from the herbaria F, MICH, and MO (acronyms by Thiers 2015). Images of additional specimens were examined online via JSTOR (2000 onward), as well as the virtual herbaria maintained by COL (www.biovirtual.unal.edu. co/ICN), P (science.mnhn.fr/all/search), NY (sciweb.nybg.org/science2/VirtualHerbarium.asp), and UDBC (herbario.udistrital.edu.co/herbario/). A few additional specimen images were provided by curatorial staff at US, MO and RB. Specimens 
examined from online images only are cited with barcode number in brackets. Material from USM was studied from handheld digital camera photos, cited with "photo" in brackets. Specimens are listed by country in a north-south sequence, with Venezuela following Colombia, and within country alphabetically by province in boldface, and then by collector and number. In a few cases where practical, geographic groupings within provinces are also used and these are also in boldface.

Specimen localities were interpreted according to the label description and in some cases, published collecting records, and mapped manually using the Google "My Maps" application. Coordinates of the manually placed markers were retrieved as KML data. Final distribution maps were generated using ArcGIS. Estimated coordinates used for mapping are included in the Suppl. material 2.

The key characters used to differentiate Paepalanthus subsect. Dichocladus from $P$. subsect. Cryptanthella in the key were based on examination of the following vouchers. Paepalanthus dichotomus var. glabrescens: Peru. Amazonas: Chachapoyas, A. Sagástegui 7454 (F), H. van der Werff 14940 \& 16912 (F), Wurdack 1388 (isotype, F). Paepalanthus ferreyrae: Peru. Cajamarca: Cutervo, J. Mostacero 1594 (F), Peru. Amazonas: Bongará, J. Wurdack 1081 (F), I. Sánchez Vega 10020 (F). Paepalanthus muscosus: Colombia. Norte de Santander, Linden 1330 (isotype, F); Venezuela. Táchira, Maas \& Tillett $5282(\mathrm{~F})$.

Leaf anatomy of the $P$. pilosus complex was studied from median hand sections of dried herbarium specimens. Leaves were boiled, stored in $70 \%$ alcohol, then rinsed, hand-sectioned in water, and mounted in 50\% glycerine. Anatomical vouchers are as follows. Paepalanthus caryonauta Hensold: Barclay 5176 (F), Boyle 4219 (F), Fuentes $13574(\mathrm{~F})$, Monteagudo 16143 (F), Valenzuela 8117 (F); P. dendroides: Leon 2243 \& 2683 (F), Vásquez 29038 (F); P. huancabambensis Hensold: Sagástegui $16799(\mathrm{~F})$; P. pilosus var. pilosus: Barbour 3427 (F), Jørgensen 1817 (F), 2209 (F); P. pilosus var. leoniae Hensold: León 1597 (MO). Paepalanthus lodiculoides was not sampled due to difficulty sectioning the very small leaves.

Floral measurements were made by ocular micrometer in a stereomicroscope. Except for the Colombian, Venezuelan and Central American material of $P$. dendroides and $P$. pilosus, flower samples of all available specimens were measured. Photos of dry flowers, seeds and some capitula were taken with a Dino-Lite AM-413T USB Digital Microscope (Figs 2, 5, 7, 9, 10, 12), and if necessary multiple images aligned and stacked in Photoshop. Seeds were photographed after wetting and re-drying to show hygroscopic structures. Figures 4D and 9B were photographed under a stereomicroscope, and leaf cross-sections (Fig. 3) were photographed under compound microscope. Figures 3F and 9B were compiled with Zerene Stacker software.

Conservation status could be assessed with confidence only for taxa of very broad and very narrow distribution. Confident evaluation according to the IUCN (2014) criteria was difficult due to the patchy nature of suitable habitat in the Andes, my lack of fieldwork, and insufficient knowledge regarding rate of habitat loss and other threats. For the taxa not assessed, I offer only notes which may be relevant to the subject, such as a rough estimate of distributional range. 


\section{Morphology}

Habit

All species in the group are perennials with a compact, flat to rounded (pulviniform) cushion habit, formed by short densely branched sympodial stems covered with congested subulate leaves about 1-2 cm long. Inflorescences are solitary and terminal on young shoots, but soon overtopped by erect lateral shoots, and then appear either axillary or borne between two dichotomous branchlets. The cushions may reach up to 1 $\mathrm{m}$ in diameter (P. caryonauta) and $10 \mathrm{~cm}$ high (P. pilosus), with a hemispherical shape (Fig. 1), though they may be much smaller. Aubert et al. (2014b), applying Rauh's (1939) taxonomy of cushion plant forms, categorized the cushion-forming Eriocaulaceae as the "Rasenpolster" type, or "tufted compact cushion," and presented P. pilosus ("P. karstenii") as an illustration of this growth form. This type of cushion is typical of herbaceous graminoids, in which a central taproot is lacking, and adventitious rootlets issuing from the leaf bases anchor it to the soil. It is perhaps translated more accurately as "turf cushion" (cf. Parsons and Gibson 2009). As cushions grow, dead organic matter accumulates in the interior (Fig. 1A, foreground). Later the older growth at the center may rot away, so that the cushion becomes ring-shaped (A. Cleef, pers. comm.). This is illustrated in a photograph by Cleef of $P$. lodiculoides var. floccosus Moldenke in the field (see Moldenke 1976, p. 50).

\section{Leaf morphology}

Leaf morphology is similar among species, with subtle differences found in color, thickening, and pubescence. Paepalanthus huancabambensis is distinguished by a deep blue-green leaf color, while $P$. dendroides has leaves distinctly pale green in drying. In other species, leaf color is variable. The upper leaf surface is persistently pubescent in $P$. huancabambensis and in $P$. dendroides of Huánuco and Cuzco. In $P$. pilosus of Peru and Ecuador, appressed pubescence commonly occurs on the upper surface near the apex, while robust scattered cilia extending to the distal margin are typical of plants from the northern part of the range. Paepalanthus caryonauta has a rounded leaf apex (Fig. 2C), with the cuspidate tip strongly deflexed if present, while P. pilosus has leaves acute to sharply aristate (Fig. 2D, F, H, J), and the other species have leaves acute but not aristate (Fig. 2A, E).

\section{Leaf anatomy}

The 13 specimens sampled represent all taxa of the $P$. pilosus complex except $P$. lodiculoides. Their anatomy may be characterized as follows: Epidermal layer one cell thick of large rounded cells, with those of the upper epidermis slightly larger than the lower 

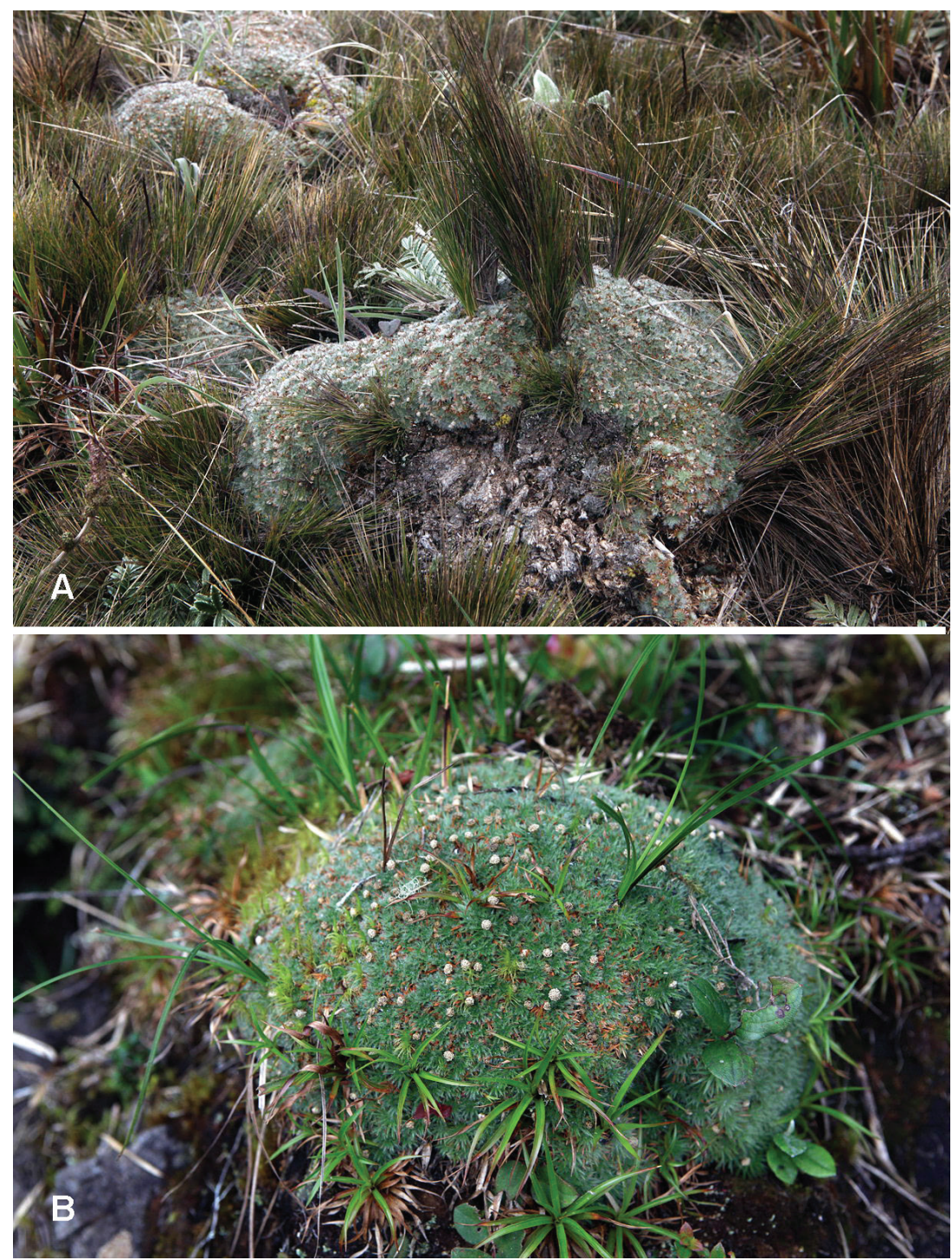

Figure I. Cushion habit of Paepalanthus pilosus var. pilosus in Venezuela, November 2012. A P. pilosus cushions with bunchgrasses, Páramo Batallón B Individual cushion, with graminoids emerging, Páramo Los Conejos. Photos by Serge Aubert, Station Alpine Joseph Fourier, France. Used by permission (www. cushionplants.eu).

epidermis; leaf margin rounded, with smaller usually thicker-walled cells. Stomata abaxial only. In P. dendroides, the epidermal cells larger and mostly thinner-walled than in the other samples, partly collapsed and deformed in section. In other sampled taxa, the outer epidermal wall thickened, and sometimes heavily cutinized on one or both surfaces. Hypodermis absent. Mesophyll of dense to moderately loose short-armed chlorenchyma, with an adaxial palisade layer sometimes discernible. Veins mostly 5-7. 
Vein buttresses (bundle sheath extensions) commonly absent in median section (Fig. 3A-E), with exceptions. In P. huancabambensis the three central veins were buttressed adaxially, and also more weakly or by the midvein only to abaxial epidermis (Fig. 3F). In $P$. caryonauta, a weak abaxial midvein buttress was noted in only one specimen, otherwise buttresses absent. All other samples studied lacked vein buttresses in median section, though they likely occur towards leaf base.

Some unusual anatomical features are present which may relate to the daily freezethaw cycles of high elevation paramo. First, the mesophyll often detaches cleanly from the epidermis in an intact layer enclosing the vascular bundles. This was conspicuous in the thick leaves of P. caryonauta and observed to some extent in all sampled taxa except $P$. huancabambensis. It can be seen in dry broken leaves, as well as in hydrated sections. Separation of mesophyll from the epidermis is known from petioles and leaves of various frost-resistant species of other families in connection with extracellular ice formation (Levitt 1956). In these species, extracellular ice crystals can form below the epidermis, drawing water from the parenchyma and causing it to shrink. The cells themselves do not freeze and the tissue rehydrates when it thaws, avoiding permanent damage. McCully et al. (2004) speculate that anatomically determined "fault zones" which accommodate subepidermal ice crystals enhance frost resistance in some species.

Unusual deformation of the bundle sheaths is also observed in some species. In $P$. caryonauta, $P$. huancabambensis, and most $P$. pilosus, cells of the bundle sheath ("endodermis" sensu Coan et al. 2002) are regularly rounded or only slightly compressed (Fig. $3 \mathrm{~A}, \mathrm{~F})$. However, in the observed material of $P$. dendroides and $P$. pilosus var. leoniae they are irregular in shape, sometimes flattened so completely the inner walls touch, and the cells lateral to the bundles extend outward in characteristic finger-like rays (Fig. 3C-E). This peculiar feature was observed even in young leaves. Partial distortion of the bundle sheath was also observed in P. pilosus var. pilosus (Fig. 3B). The semi-aquatic species $P$. dendroides tends to have thinner cell walls, which may be expected to deform more easily. However, $P$. pilosus var. leoniae, which occurs at the highest elevation for that species in Peru, in spite of its thicker cell walls, also showed highly distorted bundle morphology, with cells of the bundle sheath and phloem barely discernible. While some distortion of cells is to be expected due to the drying process, the consistent differences observed between taxa growing at similar elevations suggest other factors are involved.

\section{Timing of peduncle elongation}

Paepalanthus pilosus var. pilosus is distinguished, especially in Peru and Ecuador, by the capitula usually subsessile and partly contained within the peduncle sheaths at flowering time (Fig. 2J). However, the peduncles often elongate dramatically in fruit, up to 10 times or more their length at anthesis (Fig. 11D). This delayed timing may serve to protect flowers at anthesis while enhancing fruit dispersal in the extreme páramo habitat. Although peduncle length is known to be variable in this species, the correlation of elongation with fruiting has not been previously noted. In the other species, dwarf 


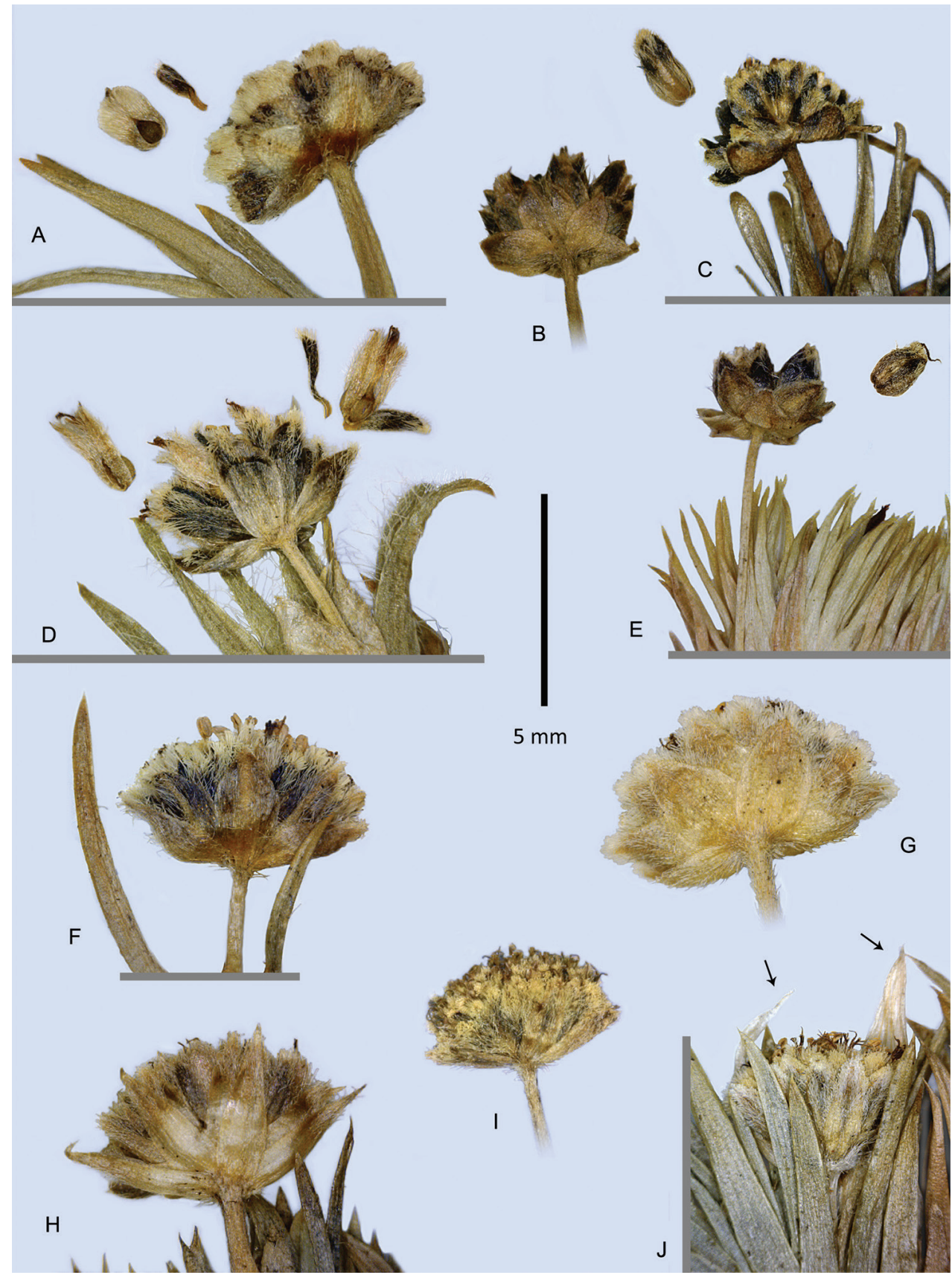

Figure 2. Capitula and leaf tips of Paepalanthus pilosus and relatives A-E Fruiting capitula with diaspores; sepals detaching $(\mathbf{A}, \mathbf{D})$ or intact $(\mathbf{C}, \mathbf{E}) \mathbf{A} P$. dendroides B-C $P$. caryonauta D P. pilosus var. pilosus $\mathbf{E}$ P. lodiculoides $\mathbf{F}-\mathbf{J} P$. pilosus var. pilosus, involucral bract variation. Arrows $=$ tips of the torn peduncle sheath. (A Davidse 28991 B Barclay 5176, Ecuador C Dudley 11060, Peru D Cuatrecasas 25574 E Øllgaard 9717 F Cuatrecasas 25882 G Cuatrecasas 5553 H Øllgaard 9557 I Cano 16840 J Jorgensen 2366.) 
peduncles occasionally occur, probably in response to habitat, and slight elongation may occur after flowering, but not to the dramatic degree observed in P. pilosus.

\section{Arrangement of staminate and pistillate flowers}

Most species have protogynous capitula, with pistillate flowers at the periphery, and staminate flowers in the center. The capitula are about 4-24-flowered and usually strongly determinate, with no central floral primordia found at the start of anthesis. In capitula with relatively more flowers (P. huancabambensis, some $P$. pilosus) the ratio of pistillate to staminate flowers tends to be greater (up to 3:1) whereas in smaller capitula it approaches equality. The related taxon, treated as "Paepalanthus sp. A" below, differs by the flowers more numerous ( 40 or more) and the pistillate and staminate disposed in alternating whorls, with staminate flowers sometimes found in the outer whorl (Fig. $11 \mathrm{G})$. An unusual situation is found in $P$. lodiculoides, in which a variable sex ratio may be observed among capitula on the same plant. Wholly staminate capitula are frequent in this species, while bisexual capitula show variable ratios of pistillate to staminate flowers. Wholly pistillate capitula were not observed.

\section{Nectaries}

In Paepalanthus and other genera of the Paepalanthoideae, modified style branches may function as nectaries (Stützel 1984, Oriani et al. 2009). These clavate structures have traditionally been termed "stylar appendages," (e.g., Ruhland 1903), but Stützel (1984), noting their homology to a style branch itself, substituted the term "Drüsen" (glands), and later "gynoecial nectaries" (Stützel and Gansser 1996), while Rosa and Scatena (2007), suggested "nectariferous branches of the style." Similar secretory structures in the base of the staminate corollas are sometimes termed pistillodes. For simplicity I have used the term "nectary" for these structures, which are similar in both the pistillate and staminate flowers of the species treated here.

In P. lodiculoides (Fig. 10D) and P. dendroides (Fig. 7G) nectaries are usually colorless, weak and membranous, curving slightly or collapsing after anthesis. However, in southern Peru, nectaries of $P$. dendroides may be light pink or brown. In the staminate flowers of these two species, the nectaries are well included in the corolla, only reaching about halfway to the sinuses of the tube. All other species have rigid dark brownish nectaries, which reach the sinuses of the corolla tube in the staminate flower, and are often well exsert from the pistillate flowers, especially in fruit. In P. pilosus (Fig. 12B, D, I) and P. huancabambensis (Fig. 9I) the papillae rimming the top of the nectary are stiff-walled and mostly colorless, only partially collapsing after anthesis and contrast strongly with the dark-pigmented body of the nectary. Stiff-walled apical papillae may also be developed, to a lesser degree, in Peruvian specimens of $P$. dendroides. In Paepalanthus caryonauta (Fig. 5G) the apical papillae are less clearly differentiated in texture and color, and the whole structure uniformly dark brown. 


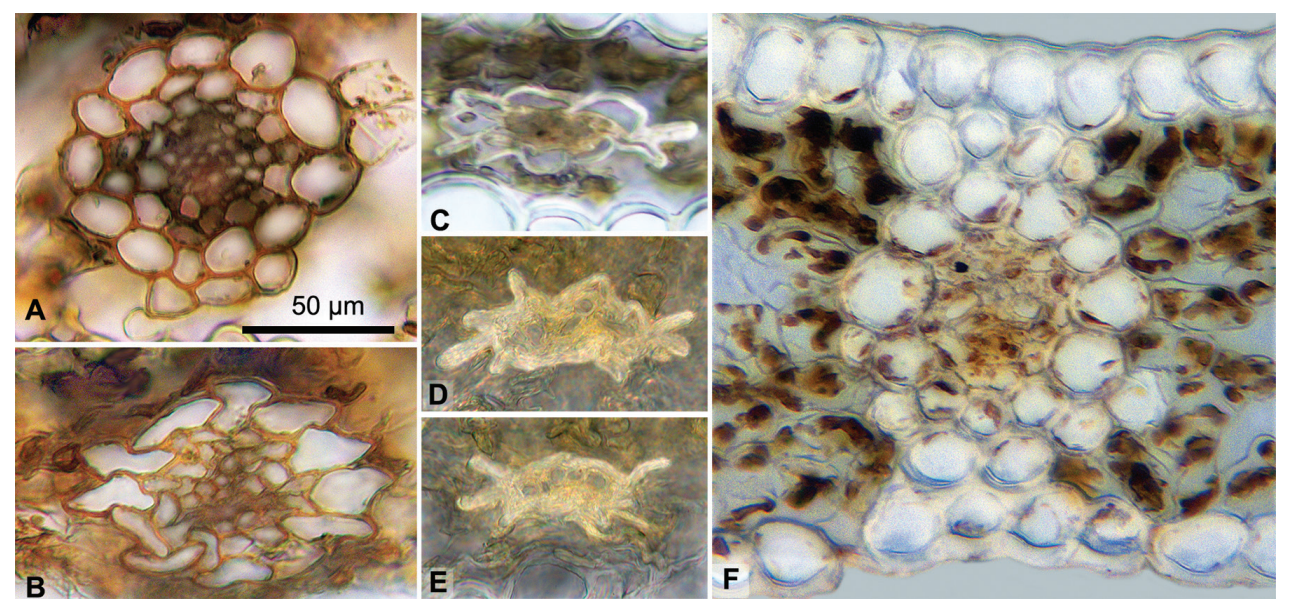

Figure 3. Vascular bundle morphology, adaxial side up. A Paepalanthus caryonauta B $P$. pilosus var. pilosus C-E P. dendroides $\mathbf{F}$ P. huancabambensis midvein, with bundle sheath extensions. (A Valenzuela 8117 B Barbour 3427 C León 2683 D-E León 2243. F: Sagástegui 16799 D-F Mesophyll darkened for contrast.)

\section{Diaspores}

In $P$. dendroides, $P$. huancabambensis, and $P$. pilosus var. pilosus the basal half of the fruiting sepals thickens along the midvein at maturity and recurves hygroscopically upon drying, presumably pushing the detached corolla and fruit upward to the capitulum surface (Figs 2A, D; 7E; 12G, H). This is similar to the "elevator mechanism" of dispersal, described by Trovó and Stützel (2011) for P. tortilis (Bong.) Körn. However, in P. tortilis, the tips of the sepals recurve sharply, while in the taxa described here, only the sepal bases thicken and reflex, and the apex remains angled upward. The pilose corolla remains tightly attached to the fruit and is dispersed with it, leaving the sepals behind. In $P$. dendroides and to some extent in $P$. huancabambensis, the petals are broadly spatulate and densely pilose (Fig. 7), perhaps further facilitating dispersal, while in $P$. pilosus the persistent petals are relatively narrow (Fig. 12E, G). However, in P. pilosus the hygroscopic pseudotrichomes (rod-like epidermal wall remains) of the seed coat are slightly stiffer and more prominent than in any of the other species, while those of $P$. dendroides tend to be weak and flaccid ( $c f$. Figs 5, 7, 10, 12). Melcher et al. (2004), in a broad survey of paramo taxa, assumed on the basis of morphology that $P$. pilosus (" $P$. karstenii") is primarily wind-dispersed and secondarily water-dispersed. They found that diaspores of this species will float for at least three days and suggested that the persistent pilose petals, and perhaps the pseudotrichomes of the seeds, may function to trap air bubbles. SEM photos of the diaspore and seed are provided by Melcher et al. (2004). The diaspores of P. caryonauta (Fig. 2B-C, Fig. 5K-M), P. lodiculoides (Fig. 2E, Fig. 10E), and P. pilosus var. leoniae (Fig. 12L) are of a different type. In these taxa, both sepals and petals are uniformly thickened in fruit, the broad-based sepals strongly cymbiform-clasping, and the fruit dispersed enveloped by the entire perianth. The fruiting sepals lack any hygroscopic change in shape, and the swollen diaspores 
detach readily from the capitulum. Sepal thickening is best developed in the Peruvian populations of $P$. caryonauta, the thickening extending into the pedicels of the pistillate flowers, which persist as conspicuous "stumps" on the otherwise naked receptacle after flower fall. To compare to Melcher's results with $P$. pilosus, I tested flotation of two diaspores of $P$. caryonauta (Barclay 5136, Dudley 11194), which also floated for three days, probably due to the buoyancy of the thickened perianth tissue. Relative to $P$. pilosus and $P$. dendroides, however, wind dispersal in this species may be inhibited due to the increased weight and glabrate surface of the diaspore.

The staminate flowers of $P$. caryonauta also incidentally thicken with age (Fig. 5J), the corolla developing a thick columnar anthophore, possibly as a pleiotropic effect of the pistillate flower thickening. In the Peruvian plants the staminate flower pedicels are obsolete. In other species, the anthophore is membranous or fleshy but narrowed toward the base, and staminate flowers are normally pedicellate.

\section{Pathology}

Smut fungus infection was observed in both $P$. dendroides (Nuñez 7773, Tupayachi 50) and P. pilosus var. pilosus (Sagástegui 12242). In these specimens the compact black spore masses swelling the ovary locules simulate mature fruit.

\section{Ecology and distribution}

Paepalanthus pilosus and allies occur strictly in wet and very wet paramo and subparamo formations of the Andes, often associated with Sphagnum. Most taxa, except for $P$. dendroides, occur at about $3100-4000 \mathrm{~m}$ on wet but probably not inundated sites. Of these, $P$. pilosus and $P$. caryonauta are the most similar in habit, both forming dense mats or cushions $30 \mathrm{~cm}$ or more in diameter and reported as locally abundant. Paepalanthus pilosus is the more commonly collected species, noted for its colonization of disturbed sites, and often cited in ecological studies of paramo as "P. karstenii." Further detail is found in the species discussions.

The principal distributions of $P$. pilosus and $P$. lodiculoides, on one hand, and $P$. caryonauta on the other, form an allopatric mosaic with respect to each other (Figs 6, 8). In Colombia, P. caryonauta is found primarily in the central Cordillera, barely entering northern Ecuador at Páramo Angel, while P. pilosus is abundant in the eastern Cordillera and the Cordillera de Merida, Venezuela. Paepalanthus pilosus reappears in southern Ecuador and northern Peru, from the natural barrier of the Girón-Paute valley (cf. Jørgensen et al. 1995), continuing south through the Amotape-Huancabamba zone (sensu Weigend 2002, 2004). Paepalanthus caryonauta, in turn, is found at several localities from Central Peru south to La Paz, Bolivia, on the wet eastern slope. Paepalanthus lodiculoides, though less widespread, has a disjunct distributional pattern in South America which parallels that of $P$. pilosus. 
Parallel disjunctions may be noted in other pulviniform Andean Eriocaulaceae. The Andean species of $P$. subsect. Dichocladus have a collective distribution similar to that of $P$. pilosus, occurring in the northern part of the eastern Cordillera of Colombia (P. muscosus), and in the Amotape-Huancabamba Zone ( $P$. dichotomus var. glabrescens, P. ferreyrae). On the other hand, Eriocaulon microcephalum, which occurs in the Central Cordillera of Colombia and northern Ecuador, as well as in central Peru has an Andean distribution paralleling that of $P$. caryonauta, but also touching the edges of the Amotape-Huancabamba Zone. In Ecuador, it reaches to southern Azuay (specimen data from TROPICOS 2015), but mostly occurs to the west of the Azuay populations of $P$. pilosus, on the opposite side of a presumed Pleistocene glacial migration barrier (Jørgensen et al. 1995, Fig. 3; Lozano et al. 2009, Fig. 1). From central Peru it reaches north into San Martín, where it is sympatric with $P$. pilosus var. leoniae.

Paepalanthus dendroides has a wide patchy range that overlaps that of both $P$. caryonauta and $P$. pilosus (Fig. 8), but generally occurs at lower elevations than the other taxa, mostly at 2400-3200 m, but as low as $1900 \mathrm{~m}$ in Antioquia, Colombia (Luteyn 10737) and up to $3800 \mathrm{~m}$ in southern Peru. It is the only species sometimes described as an emergent aquatic. It is also the only species of the group to be collected from the mountains of the Guiana Shield (Pico de Neblina, Venezuela-Brazil border). Together with $P$. pilosus it extends to Panama and Costa Rica as well, perhaps reflecting the adaptation of the lightweight comose diaspores of these species for long-distance dispersal.

\section{Hybridization}

A number of suspected hybrids were detected in areas of sympatry. These include a sterile intermediate between $P$. dendroides and $P$. caryonauta in Pasco, Peru, discussed under $P$. dendroides. In addition, material morphologically intermediate between $P$. caryonauta and $P$. pilosus has been collected in Colombia in areas marginal to the distribution of both species. At the Paramo de Frontino in the western Cordillera, an apparently fertile intermediate plant was found sympatrically with normal $P$. pilosus, and a similar intermediate, with abortive flowers, was collected at the south end of the eastern Cordillera. Typical $P$. caryonauta is not known from either locality. (See $P$. caryonauta discussion.) Finally, as discussed under $P$. pilosus, long-term introgression with $P$. dendroides, or perhaps another local taxon, is suspected as a factor contributing to the unusually broad, and perhaps bimodal pattern of variation observed in P. pilosus in disturbed paramos near Bogotá, Colombia, but more study is needed.

\section{Taxonomic affinities and placement}

Ruhland (1903) placed P. pilosus (including P. dendroides) and P. karstenii in Paepalanthus series Leptocephali Ruhland, an artificial group of reduced mostly annual species 
with erect stems and terminal fascicles of inflorescences. However, P. pilosus and allies are perennial cushion plants with inflorescences borne singly, and are clearly out of place here. This misinterpretation may have been due to the fragmentary material available to Ruhland, as well as to Kunth's mischaracterization of $P$. dendroides as having inflorescences in terminal umbellate clusters.

A convenient alternative placement for these plants is available in the overlooked subsection Paepalanthus sect. Paepalanthus subsect. Cryptanthella Suess., described to accommodate $P$. kupperi Suess. (syn. of $P$. pilosus) from Costa Rica. Suessenguth (1942) compared the new subsection to Paepalanthus subsect. Dichocladus Ruhland, a group characterized by its subdichotomously branched cushion habit. He distinguished $P$. subsect. Cryptanthella by the subterranean branching, with only the erect unbranched rosettes borne above ground. Solitary axillary peduncles were said to arise from near the base of these aerial stems, in comparison to $P$. subsect. Dichocladus, in which inflorescences are borne in the axis between paired dichotomous branchlets (Ruhland 1903). In fact, a similar sympodial branching pattern is found in both groups, with the peduncles terminal on erect leafy shoots at the time of initiation, but overtopped by one or two lateral shoots early in development. The apparent difference in habit is attributable to the tendency in $P$. pilosus to form prostrate mats, in comparison to the erect cushions formed by the more rigid stems and leaves in $P$. subsect. Dichocladus. However, the latter group differs sharply from the $P$. pilosus complex in a number of other characters (see key below), so Paepalanthus subsect. Cryptanthella is provisionally recognized as a distinct taxon, with a new description and circumscription here provided.

The species of $P$. subsect. Cryptanthella formally treated here are all Andean cushion plants. However, $P$. pilosus is very similar to a robust long-pedunculate taxon from páramo in the Serrania de Perijá, Colombia, discussed below under Paepalanthus species A. Further affinities of the group are not clear. It was not sampled in recent cladistic studies (Andrade et al. 2010; Trovó et al. 2013), which found a deep division of Paepalanthus (ca. 440 spp.) into two major clades not readily distinguished by morphology. Some affinity can be seen with certain long-stemmed species of $P$. sect. Polyactis Ruhland, as to branch architecture, simple style branches and tuberculate floral trichomes. These include $P$. stuebelianus Ruhland and $P$. bongardii Kunth, both with a more lax, scrambling habit. However Paepalanthus sect. Polyactis also emerged as deeply polyphyletic in the analyses, and the species most similar to P. subsect. Cryptanthella were not sampled.

\section{Taxonomic treatment}

Due to the frequent confusion and misidentification of all the Andean cushion plant taxa of Eriocaulaceae, a key distinguishing major groups is provided. 


\section{Key to major groups of Andean cushion plants in the Eriocaulaceae}

1 Roots white, spongy and compressible, easy to tear or cut, septate (with transverse partitions); leaves fenestrate at base ("windowed," with transverse tissue partitions between the veins); leaf tips acuminose, membranous, pale or discolored; peduncles and outer involucral bracts glabrous; anthers deep black; petals with a black gland on inner apex ...Eriocaulon microcephalum Kunth

1' Roots cream to brown, wiry, with persistent fibrous core, not easily broken by hand nor septate, nor leaves fenestrate; leaf tips thickened, rigid, rounded to aristate; peduncles and/or outer involucral bracts pubescent; anthers creamcolored; petals eglandular.

2 Peduncle sheaths lacking or present, and then the tips ciliate around the whole mouth, sometimes glabrate with age, occasionally splitting with age; pistillate flowers with sepals linear-ligulate, the tips recurving or recoiling in fruit; petals tufted at upper margin only, not pilose on outer surface; seeds smooth and shiny even when wetted, pseudotrichomes absent. Plants of sandy and rocky soils of jalca or montane forest openings, ca. 2000-3000 m elevation

Paepalanthus subsect. Dichocladus (Andean taxa)

2' Peduncle sheaths always present, the tips papery-thin and scarious, often splitting deeply into two or three segments before anthesis, glabrous or minutely tufted at apex, never ciliate around mouth; pistillate flowers with sepals elliptic to spatulate, the tips not recoiling in fruit, and petals prominently pilose on outer and often inner surface; seeds with a whitish covering of matted or distinct pseudotrichomes after wetting. Plants of wet paramo or subparamo often associated with Sphagnum, ca. 2000-4000 m.

Paepalanthus subsect. Cryptanthella

\section{Key to the species of Paepalanthus subsect. Cryptanthella}

$1 \quad 1.7-6.0 \mathrm{~mm}$ long, less than $0.4 \mathrm{~mm}$ wide in the middle; peduncles glabrous at apex; floral sex ratio very variable, ranging from capitula with flowers all staminate to flowers mostly pistillate.

4. P. lodiculoides

1' Leaves (5.5-) 6-22 $\mathrm{mm}$ long, 0.6-2 $\mathrm{mm}$ wide in the middle; peduncles with a dense collar of hairs at the apex surrounding the base of the capitulum; sex ratio less variable, the capitula with the number of pistillate flowers subequaling to three times more than the staminate in number. .2

2 Leaf apex narrowly obtuse to rounded, if acute, the tip curved under and not evident from above; leaves glabrous in the distal half or nearly so; sepals of the female flowers thickening uniformly at maturity, enclosing the fruit and dispersed with it

1. P. caryonauta

2' Leaf apex acute to sharp-apiculate, never deflexed; leaves commonly appressed-pilose on upper surface near tip or ciliate, rarely glabrous; sepals of 
the female flowers thickening only in a narrow strap-like zone in the basal half of the midrib, and separating from fruit at dispersal (except $P$. pilosus var. leoniae, Peru, San Martín)

3 Peduncles mostly $<7 \mathrm{~mm}$, usually shorter than the sheaths at time of anthesis, often elongating in fruit (rarely up to $50 \mathrm{~mm}$ at anthesis, Cano 16840, Piura); petals of the female flowers oblanceolate, mostly 2.2-6 times longer than wide; style base (below insertion of style branches) $0.5-1.05 \mathrm{~mm}$ long; nectaries dark, rigid . .4

3' Peduncles 20-130 $\mathrm{mm}$ at anthesis; petals of the female flowers broadly spatulate, ca. 1.6-2.3 times longer than wide; style base less than $0.35 \mathrm{~mm}$ long; nectaries various

$4 \quad$ Fruiting sepals of the female flowers with basal half of midrib thickened, otherwise remaining chartaceous 5a. P. pilosus var pilosus

4' Fruiting sepals of the female flowers uniformly thickened throughout and enclosing corolla and fruit at maturity. Plants of San Martín, Peru

5b. P. pilosus var. leoniae

Leaves pale green; peduncle sheaths $11-23 \mathrm{~mm}$, closely appressed, often hidden among the leaves; involucral bracts paler at least along the midvein; nectaries colorless to pinkish or light brown, those of the staminate flowers usually only half-equalling the corolla sinuses (except Vasquez 29038, Pasco)

2. P. dendroides

5' Leaves dark blue-green; peduncle sheaths $25-30 \mathrm{~mm}$, lax and open, much exsert from leaf mat; involucral bracts blackish brown throughout; nectaries dark brown, rigid, exsert in fruit, those of the staminate flowers equalling the corolla sinuses

3. P. huancabambensis

\section{Paepalanthus subsect. Cryptanthella Suess.}

Paepalanthus subsect. Cryptanthella Suess., Bot. Jahrb. Syst. 72(2): 293.1942.

Type. Paepalanthus kupperi Suess.

Plants cespitose or pulviniform, forming densely branched clumps with erect terminal shoots ca. 1-4 cm; inflorescences solitary, terminal, but soon overtopped by one or two sympodial branches; peduncle sheaths scarious, swollen at apex, usually splitting into two or three triangular segments; involucral bracts pale greenish to gold or blackish-brown, pilose, not or barely surpassing flowers. Trichomes of the involucral bract and sepal apices subacute to rounded at apex, tuberculate; apical trichome tuft of bracts and sepals relatively short, surpassing perianth tip by less than $0.2 \mathrm{~mm}$. Pistillate flowers peripheral, the outer subtended by the broad inner bracts of the involucre; staminate flowers central or rarely ( $P$. lodiculoides) the whole capitulum staminate; the inner flowers subtended by linear receptacular bracts, these often with sub-cucullate tips and carinate-clasping bases; pistillate flowers pedicellate; the petals usually long 
pilose abaxially with tuberculate trichomes disposed in submarginal bands in the upper $1 / 2$ to $2 / 3$ of petal, and also in two dense tufts just inside the upper margin either side of the apex and securing the stigma, the petal tips not involute after anthesis. Gynoecium with stigmas simple; stigmatic nectaries colorless to reddish or dark brown, usually with a distinctly broadened large-papillate upper rim, the papillae in the basal two-thirds or more usually indistinct and scattered. Staminate flower corolla with anthophore usually at least half the total corolla length, membranous or fleshy, corolla tube with three subacute lobes, non-involute after anthesis; staminal filaments prominently fleshy below the corolla lobes and often (not always) adnate to corolla, flat and membranous distally, the tips sometimes turning red-brown with age; anthers whitish, exsert above the lobes, not retracted after anthesis, and often deciduous. Seeds with longitudinal rows of hygroscopic pseudotrichomes.

\section{Paepalanthus caryonauta Hensold, sp. nov.}

urn:Isid:ipni.org:names:77155457-1

Figs $2 \mathrm{~B}-\mathrm{C}, 3 \mathrm{~A}, 4,5$

Diagnosis. Cushion plants with linear glabrescent leaves $1-2 \mathrm{~cm}$ long, rounded at the tip, or if cuspidate, the tip strongly deflexed. Peduncles ca. 9-25 mm, solitary, terminal at initiation, sheaths lacerate at apex, eciliate. Pistillate flowers in outer whorl of capitulum, the sepals broad, persistent, together with the petals enclosing the mature fruit at dispersal, nectaries uniformly dark brown, rigid. Staminate flowers central, with sepals fused $1 / 4-3 / 4$ of their length.

Type. PERU. Cuzco: Dist. Huayopata, sector San Luis, bosque primario intervenido, $13^{\circ} 04^{\prime} \mathrm{S}, 72^{\circ} 23^{\prime} \mathrm{W}$, ca. 3000-3500 m, 24 Nov 2006, L. Valenzuela et al. 8117 (holotype: F; isotypes: AMAZ n.v., CUZ n.v., HUT n.v., MO, MOL n.v., USM n.v.).

Description. Densely branched cushion plants, the cushions reported to reach one meter in diameter (Dudley 11194), and $15 \mathrm{~cm}$ high (Barclay 5176). Branchlets 1-5 $\mathrm{cm}$, densely and uniformly leafy. Leaves linear-subulate, $10-20 \mathrm{~mm}$ long including the open basal sheath 3-4 mm long, $1.2-1.7 \mathrm{~mm}$ wide at midpoint, ca. $2.5 \mathrm{~mm}$ wide at ampliate base; apex narrowly obtuse to rounded, if sharp-cuspidate the tip deflexed downward and not evident in adaxial view; inconspicuously appressed-pilose (rarely ciliate) in juvenile state, glabrate at maturity except for the irregularly ciliate basal sheath; "dark green and glossy" when fresh (Dudley 11060), chartaceous to subcoriaceous, the adaxial surface smooth, the abaxial surface often with margins prominently thickened in older leaves and 1-3 veins more or less salient. Inflorescences solitary and terminal, with one to four produced in succession along a sympodially branched axis, the lower appearing axillary. Peduncles (7-) 9-25 (-35) mm long, ca. 3-costate, obscurely angled, pale, glabrous to obscurely appressed-puberulent, usually with a collar of longer silvery hairs at apex investing base of involucre. Peduncle sheaths (9-) 10-17 $(-25) \mathrm{mm}$ long, equaling or surpassing the leaf mat by up to $5 \mathrm{~mm}$, the lamina (tip) of the sheath 3-4 mm long, inflated, scarious, somewhat cucullate, almost closed at the 
apex in bud before emergence of capitulum, tufted-ciliolate at apex when young, often glabrate, frequently splitting into 3 triangular segments with emergence of capitulum. Capitula 3-4 mm in diameter. Involucres subequaling flowers at anthesis; involucral bracts 2-3-seriate, the outer bracts triangular-ovate to broadly ovate, dull gold, tinged gray or occasionally blackish on shoulders; the inner bracts usually more strongly pigmented except for the paler midvein; bracts bearded apically especially along upper midvein, the upper margin short-ciliate with proximal cilia slightly longer, often early glabrate abaxially. Bract and floral trichomes obtuse to clavate, subhyaline, obscurely ornamented within and very obscurely tuberculate. Flowers about 8-14 per capitulum, the pistillate flowers peripheral, the staminate central, equalling to subequalling the pistillate in number; the receptacle sparingly pilose or pilose only toward center. Receptacular bracts equaling to subequaling flowers, broadly linear-subspatulate, ca. 6 times longer than wide, the apex often slightly cucullate and pubescent as the sepals, the base distinctly carinate, clasping. Pistillate flowers: Pedicels ca. $0.1-0.35 \mathrm{~mm}$, thick, glabrous, often becoming callose-thickened in fruit (Peru), leaving characteristic 'stumps' on the empty receptacle after abscission of flowers. Sepals broadly obovate, strongly cymbiform, with apex convex-acute to obtuse (1.35-) 1.5-2.0 mm long $\times 0.6-1.0 \mathrm{~mm}$ wide (width variable within a flower), $(0.25-) 0.35-0.4(-0.5) \mathrm{mm}$ wide at the base; black-mottled on shoulders, the midvein area paler brown; shortciliate along upper margin and bearded with longer appressed hairs on upper dorsum; membranaceous to chartaceous at anthesis, enlarging slightly and becoming uniformly thickened, and often rigid in fruit, husk-like and non-hygroscopic, enclosing the corolla and fruit and dispersed with it. Petals oblanceolate-spatulate, obtuse to often emarginate or truncate-emarginate, (1.2-) 1.35-1.7 (-1.85) mm long $\times(.35-)$ 0.4$0.7(-0.8) \mathrm{mm}$ wide, ca. 2.2-3.2 (-4.9) times longer than wide, cream to brownishtinged, with scale-like staminode at base, pilose abaxially near margins of distal half with more or less tuberculate trichomes, also densely tufted subapically within in two patches either side of the apex, which enfold the style branch; like the sepals becoming more or less rigid-thickened in fruit, the staminode also thickening and tightly adherent to both petal and ovary base. Gynoecium with ovary $0.5 \mathrm{~mm}$ at anthesis, ca. 0.85 $\mathrm{mm}$ in fruit; the style base $0.3-0.5 \mathrm{~mm}$ long; the nectaries with stalks $0.25-0.65 \mathrm{~mm}$ long, glandular portion $0.2-0.35 \mathrm{~mm}$ long, very dark brown or dark reddish, subclavate, with a ring of brown membranous papillae ca. 2-3 rows thick at the apex, the whole structure maintaining its shape after anthesis; style branches $0.6-1.0(-1.2) \mathrm{mm}$ long, usually ca. $0.2 \mathrm{~mm}$ longer than nectaries though often developing unequally, the stigmas simple, dark red-brown, non-involute after anthesis. Seeds subglobose to ellipsoid, mostly 0.6-065 mm long, 0.4-0.55 mm wide, red-brown, reticulate with short weak pseudotrichomes, sometimes glabrate. Staminate flowers: Pedicels $0.15 \mathrm{~mm}$ to obsolete. Sepals (1.2-) $1.35-1.75 \mathrm{~mm}$ long $\times 0.5-0.85 \mathrm{~mm}$, usually strongly and unequally fused at base for $1 / 4-3 / 4$ their length, obovate-navicular above, the apex obtuse-angled to broadly rounded, the tubular base often rigid and obconic at maturity; color and pubescence as in the pistillate flowers. Corolla including anthophore $1.35-1.9 \mathrm{~mm}$; the anthophore $0.65-1.35 \mathrm{~mm}$ long, usually ca. $60-70 \%$ the corolla 


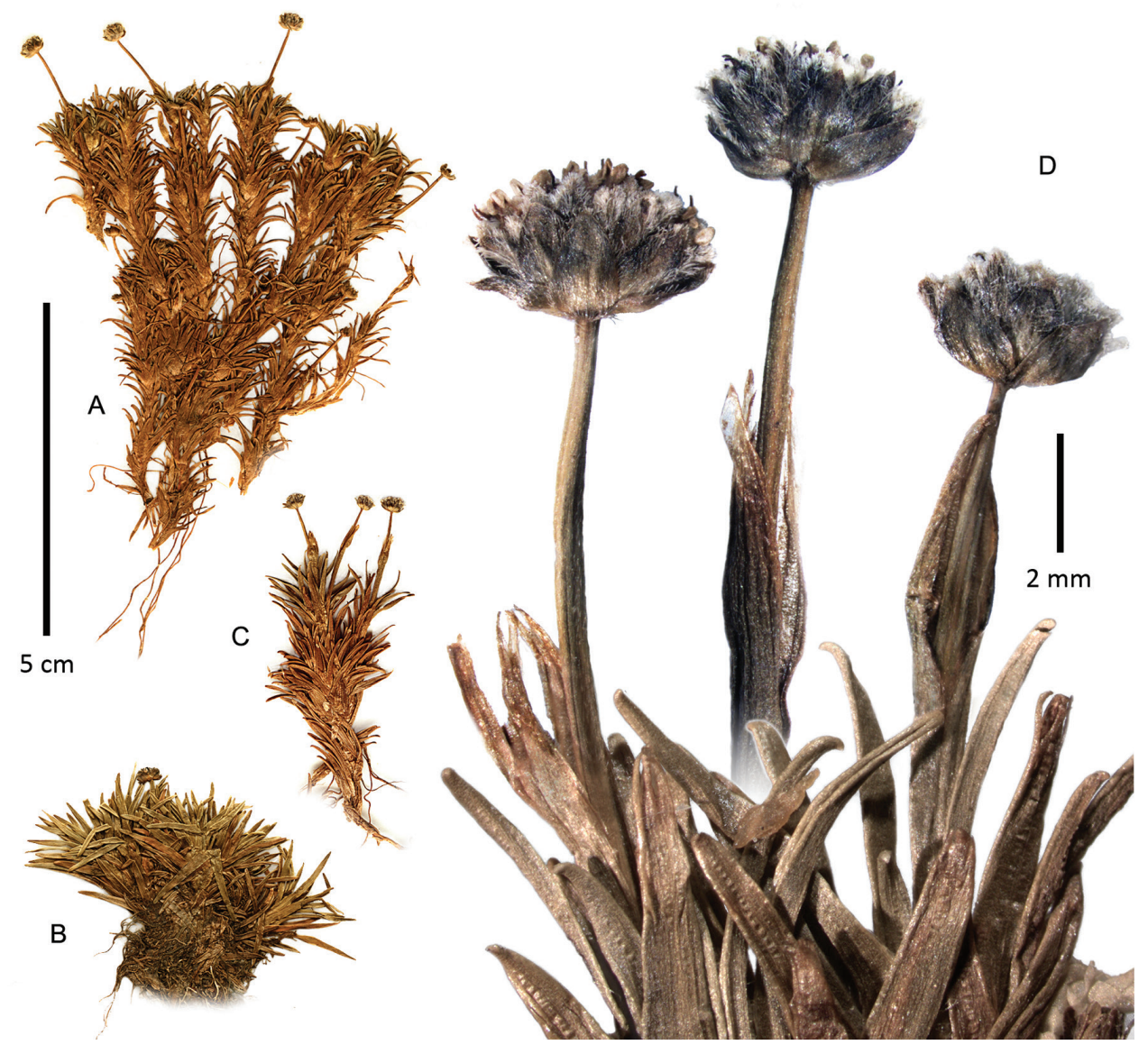

Figure 4. Habit of Paepalanthus caryonauta A Boyle 4219 B Fuentes 15374 C-D Valenzuela 8117.

length, ca. $0.2-0.35 \mathrm{~mm}$ diameter at base, fleshy and columnar at maturity; the corolla tube $0.35-0.75 \mathrm{~mm}$ deep, fleshy towards base especially opposite the filaments, the corolla lobes hyaline to brownish, obtuse, $0.15-0.35 \mathrm{~mm}$, not involute after anthesis; intermediate lobes lacking. Stamen filaments with the basal half fleshy, terete and adnate to the corolla, abruptly narrowed and loosely adhering to the lobes above, exsert $0.2-0.5 \mathrm{~mm}$ beyond the lobes, the exsert portion dark reddish-brown especially at tip; anthers cream-colored, ca. $0.3-0.35 \mathrm{~mm}$ long, usually deciduous after anthesis and not present in fruiting capitula. Nectaries similar to those of pistillate flowers, reaching or slightly surpassing the corolla sinuses.

Etymology. The epithet is taken from the Greek caryonaute (nom. sing.), the name given to the "nutshell sailors" in Lucian of Samosata's tale True Stories. It refers to the diaspores enclosed by the thick buoyant perianth.

Phenology. In Peru and Bolivia, collected in early anthesis in November and December, and with older inflorescences in all months from February to September. The 
dry season here is May to August but mitigated at higher elevations by cloud cover (Boyle 2001; Cano et al. 1995). In Colombia and Ecuador, collected on the wet eastern slopes in the slightly drier periods June to September and January; and on the drier western slopes, in the wetter months of March and December (Rangel-Ch. 2000).

Distribution. Colombia (Central Cordillera): Cauca, Nariño. Ecuador: Carchi, probably Sucumbíos. Peru: Cuzco, Junín, Pasco. Bolivia: La Paz. In addition, some atypical specimens or hybrids (see below) are known from the Western and Eastern Cordilleras of Colombia, in Antioquia, Meta, and Norte de Santander. (Fig. 6)

Habitat. In Peru and Bolivia, this species is restricted to a narrow band of wet paramo-like habitat on the high eastern slope of the Andes, while in Ecuador and Colombia it is found in open wet páramo. It is reported from boggy wet bunchgrass meadows (pajonal) with Calamagrostis Adans. or Festuca procera Kunth, in shallow waterlogged soil of ridgetops and rocky slopes, and in cloud forests and páramo degraded by fire. In Ecuador and Colombia also reported from depressions in Espeletia páramo. Boyle (2001) describes the species as common in the Cordillera Vilcabamba (Peru: Cuzco/ Junín), forming a cushiony matrix together with mat-forming species of Xyris Gronov. and Apiaceae between tussocks of Calamagrostis. Elevation (2940-) 3100-4000 m.

Conservation notes. This species is known from two disjunct paramo zones, one about $475 \mathrm{~km}$ long in the northern Andes and one $950 \mathrm{~km}$ long in the central Andes. However, unlike related $P$. pilosus, it is not reported from disturbed areas, and rare outlying populations in Colombia show signs of introgression with $P$. pilosus. In the event of climatic drying or warming this species would be vulnerable, especially in the southern part of its range where suitable habitat is narrowly restricted to the eastern slope.

Misapplied names. Paepalanthus karstenii f. corei sensu Moldenke (1983) in part, Hensold (2014), non (Moldenke) Moldenke; Paepalanthus muscosus sensu R.C. Foster (1958), Moldenke (1979) in part, Balslev (2001) in part, non Körn.; Paepalanthus pilosus Brako and Hensold (1993) in part, non (Kunth in H.B.K.) Kunth.

Dicussion. This species is most similar to $P$. pilosus, with a similar cushion-forming habit and similar habitat, and is often confused with that species (or "P. karstenii"). In his later annotations, Moldenke frequently identified this species as $P$. karstenii $\mathrm{f}$. corei (Moldenke) Moldenke. It has also frequently been distributed as $P$. muscosus (subsect. Dichocladus), which also has rounded leaf tips. The report of $P$. muscosus from northern Ecuador by Balslev (2001) is based on vouchers of both $P$. caryonauta and E. microcephalum. The species recently cited as P. muscosus (Moscol and Cleef 2009) and Paepalanthus sp. (Coombes and Ramsay 2001) in vegetation studies of cushion mires in northern Ecuador thus may correspond to P. caryonauta in part or full, but confirmation is needed.

Paepalanthus caryonauta is readily distinguished from typical P. pilosus and $P$. dendroides by the obtuse leaf tips, and by the sepals uniformly thickened and persistent in fruit, to form an ovoid-ellipsoid diaspore. Even in anthesis, the sepals of $P$. caryonauta are about twice as broad at the base as those of P. pilosus and P. dendroides. Paepalanthus caryonauta can also be recognized by eye due to subtle differences in aspect and leaf orientation, with the leaves commonly flatter and more ascending, i.e., less 
Table I. Character comparison of P. caryonauta, P. dendroides, and P. pilosus.

\begin{tabular}{|c|c|c|c|}
\hline & Paepalanthus dendroides & Paepalanthus pilosus & $\begin{array}{l}\text { Paepalanthus } \\
\text { caryonauta }\end{array}$ \\
\hline Habitat & $\begin{array}{l}\text { Terrestrial or emergent aquatic; } \\
1900-3200 \mathrm{~m} ; \\
\text { to } 3900 \mathrm{~m} \text { in Cuzco } \\
\end{array}$ & \multicolumn{2}{|c|}{$\begin{array}{l}\text { Terrestrial, not in standing water; } \\
(2900-) 3100-4000(-4300) \mathrm{m} .\end{array}$} \\
\hline Leaf apex shape & Convex-acute to acute, cuspidate & $\begin{array}{l}\text { Acute, cuspidate to short- } \\
\text { aristate }\end{array}$ & $\begin{array}{l}\text { Narrowly rounded; if } \\
\text { cuspidate, tip sharply } \\
\text { deflexed }\end{array}$ \\
\hline $\begin{array}{l}\text { Leaf pubescence at } \\
\text { adaxial apex; at distal } \\
\text { margins }\end{array}$ & $\begin{array}{l}\text { Glabrous to persistently } \\
\text { hirsutulous; } \\
\text { not ciliate }\end{array}$ & $\begin{array}{l}\text { Glabrous }\left(\mathrm{N}^{*}\right) \text { to pilose } \\
(\mathrm{S}) \text {; often prominent long } \\
\text { scattered cilia }(\mathrm{N})\end{array}$ & $\begin{array}{l}\text { Early glabrate; not } \\
\text { ciliate }\end{array}$ \\
\hline Peduncles & $20-130 \mathrm{~mm}$ & $\begin{array}{c}1.5-8 \mathrm{~mm}(\mathrm{f}) \\
20-100 \mathrm{~mm}(\mathrm{fr})\end{array}$ & $7-35 \mathrm{~mm}$ \\
\hline Capitulum diameter & $3-5 \mathrm{~mm}$ & $\begin{array}{l}3-6 \mathrm{~mm}(\mathrm{~S}) \\
3-8 \mathrm{~mm}(\mathrm{~N})\end{array}$ & $3-4 \mathrm{~mm}$ \\
\hline O Sepal length & $1.2-1.9 \mathrm{~mm}$ & (1.4-) $2.0-2.7 \mathrm{~mm}$ & $1.3-2.0 \mathrm{~mm}$ \\
\hline Sepals in fruit & \multicolumn{2}{|c|}{$\begin{array}{l}\text { Hygroscopic thickening along basal midline; detaching from } \\
\text { fruit at maturity. (Except } P \text {. pilosus var. leoniae) }\end{array}$} & $\begin{array}{c}\text { Thickened throughout; } \\
\text { non-hygroscopic, } \\
\text { enclosing fruit }\end{array}$ \\
\hline $\begin{array}{c}\text { o Petals: } \\
\text { Length/Width }\end{array}$ & $\begin{array}{c}\mathrm{L} / \mathrm{W}=1.6-2.3 \\
\begin{array}{c}\text { Broadly spatulate, densely pilose } \\
\text { along upper margin }\end{array}\end{array}$ & $\begin{array}{l}\mathrm{L} / \mathrm{W}=(2-) 3-6 \\
\text { Oblanceolate, usu. acute, } \\
\text { sparingly tufted }\end{array}$ & $\begin{array}{c}\mathrm{L} / \mathrm{W}=2.2-3.5 \\
\text { Oblanceolate-spatulate, } \\
\text { obtuse; sparingly tufted }\end{array}$ \\
\hline Nectaries & $\begin{array}{c}\text { Colorless }(\mathrm{N}) \text { to pale pink-brown } \\
(\mathrm{S}) ; \text { weak, partly collapsed in old } \\
\text { flowers }\end{array}$ & \multicolumn{2}{|c|}{$\begin{array}{l}\text { Dark red-brown, rigid, erect and exsert in old } \\
\text { flowers. }\end{array}$} \\
\hline $\begin{array}{l}\text { Nectary position } \\
\hat{\jmath} \text { flower }\end{array}$ & $\begin{array}{l}\text { Only about half-reaching the } \\
\text { corolla sinuses. }\end{array}$ & \multicolumn{2}{|c|}{ Reaching the corolla tube sinuses. } \\
\hline Seeds & $\begin{array}{l}\text { Pink to orange-brown; } \\
\text { pseudotrichomes weak }\end{array}$ & \multicolumn{2}{|c|}{$\begin{array}{c}\text { Red-brown; pseudotrichomes separating when wet, } \\
\text { remaining erect }\end{array}$} \\
\hline
\end{tabular}

* $(\mathrm{N})$ and $(\mathrm{S})$ refer to northern and southern parts of species distribution.

conduplicate and recurved than is commonly seen in $P$. pilosus. Boeke, who collected $P$. pilosus and an intermediate form of $P$. caryonauta at the same locality (see below), noted that in P. pilosus, the cushions were "easy to separate" and in P. aff. caryonauta, "difficult to separate." In the Cordillera Vilcabamba Dudley reported cushions up to 3 feet in diameter (Dudley 11194). However in disturbed roadside páramo at Acjanaco, Young and Cano (1994) comment on the paucity of cushion plants, and do not recognize $P$. caryonauta (" $P$. pilosus") as a significant cushion plant species. For other differentiating characters, see Table 1.

Paepalanthus caryonauta has a more uniform morphology throughout its range than its close relatives. However, in Colombia and Ecuador the plants have less thickening in the leaves and flowers, the presence of a short pedicel in the staminate flowers, and peduncles often shorter at flowering time, approaching those of $P$. pilosus in length.

Hybridization. Paepalanthus caryonauta and $P$. pilosus are mostly allopatric, but in Colombia there are points of contact where intermediates occur. Typical P. caryonauta 
is common in the Nudo de los Pastos and Central Cordillera of Colombia, from which only one historical collection of P. pilosus is known, collected ca. 1842. However at the isolated Paramo Frontino in the Western Cordillera, typical $P$. pilosus occurs sympatrically with a morphologically intermediate form of $P$. caryonauta. These two elements were treated as "P. karstenii" and "P. karstenii var. corei," respectively, by Rangel-Ch. and Sánchez (2005). In 1976, both elements were collected from Espeletia paramo at Llano Grande, with $P$. aff. caryonauta reported from well-drained hillside (Boeke \& McElroy 269), and P. pilosus from Sphagnum bog (Boeke \& McElroy 265). Paepalanthus aff. caryonauta was re-collected at the same locality in 1986 (Roldán 402), and P. pilosus in 1989 (MacDougal \& Roldán 4463, MO). These intermediate plants produce normal seed but have intermediate diaspore morphology (Fig. 5P). The rounded glossy leaves resemble those of $P$. caryonauta, but those of Boeke \& McElroy 269 have long scattered cilia at the upper margin, a trait otherwise only known in $P$. pilosus.

In the eastern Cordillera of Colombia, P. pilosus is abundant, while only two specimens suggesting atypical $P$. caryonauta were confirmed, these from opposite ends of the eastern Cordillera, on east-facing slopes. At the south end, an intermediate plant, similar to that of Paramo Frontino, but with flowers mostly abortive, was collected from the eastern slope of Sumapaz National Park (S. Diaz-Piedrahita 2608). This location is just south of the southernmost confirmed Colombian collection of $P$. pilosus. To the north, Cuatrecasas 10302 (F), collected at the "extreme east" of Paramo Santurban (Norte de Santander) may represent $P$. caryonauta or a hybrid intermediate, differing by the light gold bracts. Sympatric taxa in this area include $P$. dendroides, typical P. pilosus, and the taxon treated below as Paepalanthus sp. A.

In southern Peru, typical $P$. caryonauta occurs in mixed populations with $P$. dendroides at the entrance to Manú National Park (Abra Acjanaco, Cuzco). Both taxa have been abundantly collected and are readily distinguished in the field (A.Cano, pers. comm.) However, in Pasco (Oxapampa), where both species also occur, a sterile intermediate between the two has been collected. (See discussion of $P$. dendroides.)

Additional specimens examined (paratypes). COLOMBIA. Cauca: Purace La Plata, 3200 m, 22 Aug 1957, Barclay 5176 (F,MO); cabeceras Rio Palo, 3700 m, 3 Dec 1944, Cuatrecasas 19099 (F). Nariño: Mpio. Tangua, Páramo de Las Piedras, 3100-3500 m, 9 Jun 2006, Baca et al. Y-118 (COL [COL000257193]). Valle del Cauca: Cabeceras Rio Tulua, 3280-3380 m, 24 Mar 1946, Cuatrecasas 20278 (F). ECUADOR. Carchi: Paramo del Angel, 3700 m, 23 Aug 1957, Barclay 5136 (MO), 28 Sep 1959, Barclay 9374 (MO); Tulcán-Maldonado hwy, km 29, 3845 m, 24 Jan 1977, Boeke 803 (MO); Paramo El Angel, 3500 m, 4 Jan 1973, Humbles 6086 (MO); Rd Tulcán-Maldonado, km 38, 4000 m, 4 Aug 1976, Øllgaard \& Balslev 8460 (MO). PERU. Cuzco: Prov. La Convencion, Cordillera Villcabamba W slopes, $12^{\circ} 36^{\prime} \mathrm{S}$, 7330'W, 3100-3500 m, 14 Jul 1968, Dudley 11060 (F), 28 km NE of Hda. Luisiana and Rio Apurimac, 12 30'S, 73³0"W, 3400-3600 m, 17 Jul 1968, Dudley 11194 (F(2),MO,USM); Huayopata, 7 km from Incatambo, S side of Río Lucumayo, 3430 m, 4 Aug 1982, Peyton \& Peyton 914 (MO). Cuzco: Prov. Paucartambo, Parque Nac. del Manú, Alturas de Lali, 3750-3850 m, 18 Jul 1990, Cano 3872 (F, USM n.v.), 


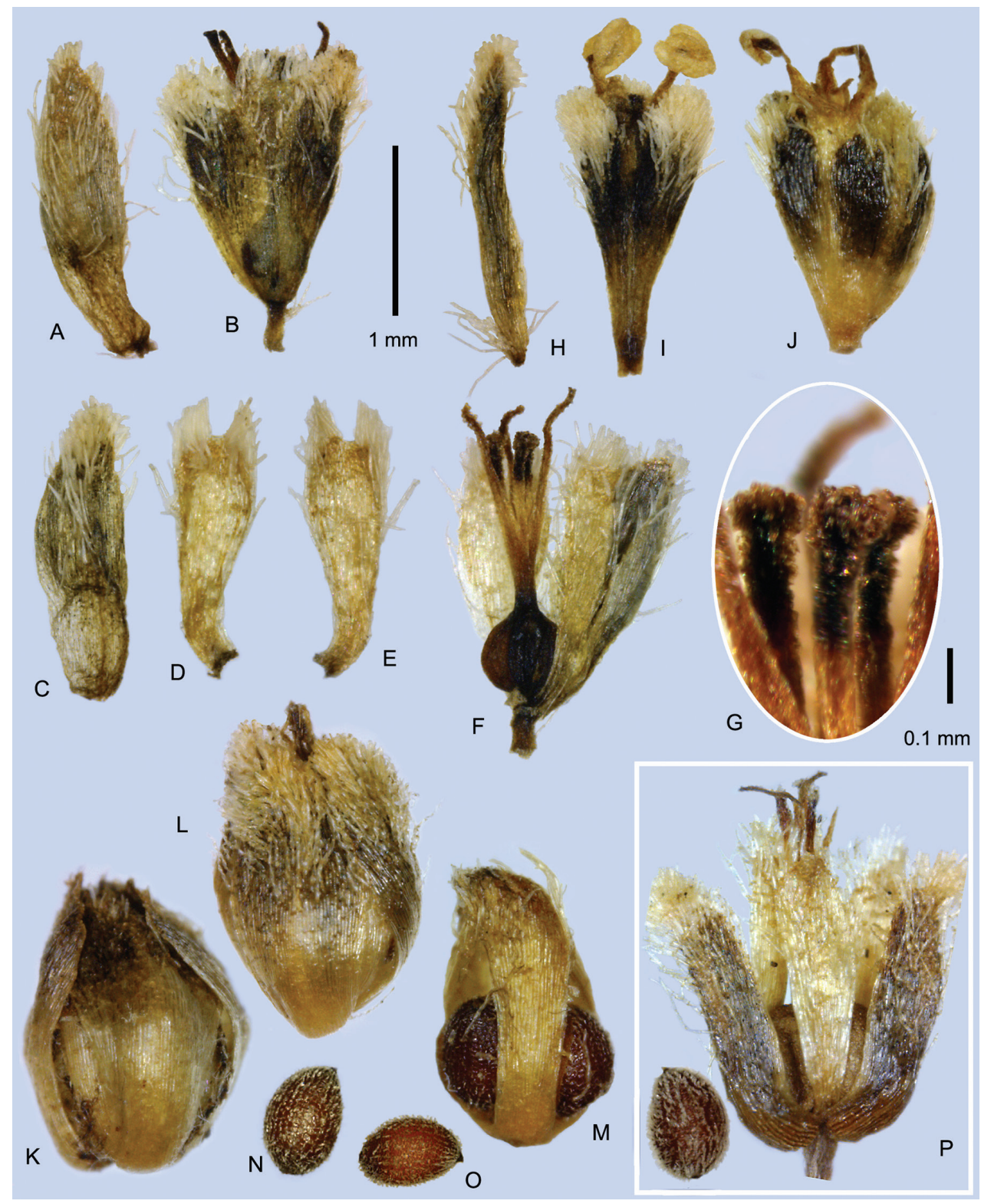

Figure 5. Flowers of Paepalanthus caryonauta (A-O) and suspected hybrid (P). A-G Pistillate flowers in anthesis A Involucral bract subtending flower B Whole flower C Sepal (abaxial) D Petal, adaxial E Petal, abaxial F Flower with one petal and two sepals removed G Gynoecial nectaries $\mathbf{H}-\mathbf{I}$ Staminate flowers in anthesis $\mathbf{H}$ Floral bract I Flower J Staminate flower showing post-anthesis thickening, two anthers fallen $\mathbf{K}-\mathbf{L}$ Mature diaspores $\mathbf{M}$ Diaspore with sepals removed, with thickened petals $\mathbf{N}-\mathbf{O}$ Seeds $\mathbf{P}$ Mature flower of probable hybrid (Roldán 402), with seed. (A-I, N Valenzuela 8117 J-K Dudley 11060 L, O Boyle 4219 M Dudley 11194). 


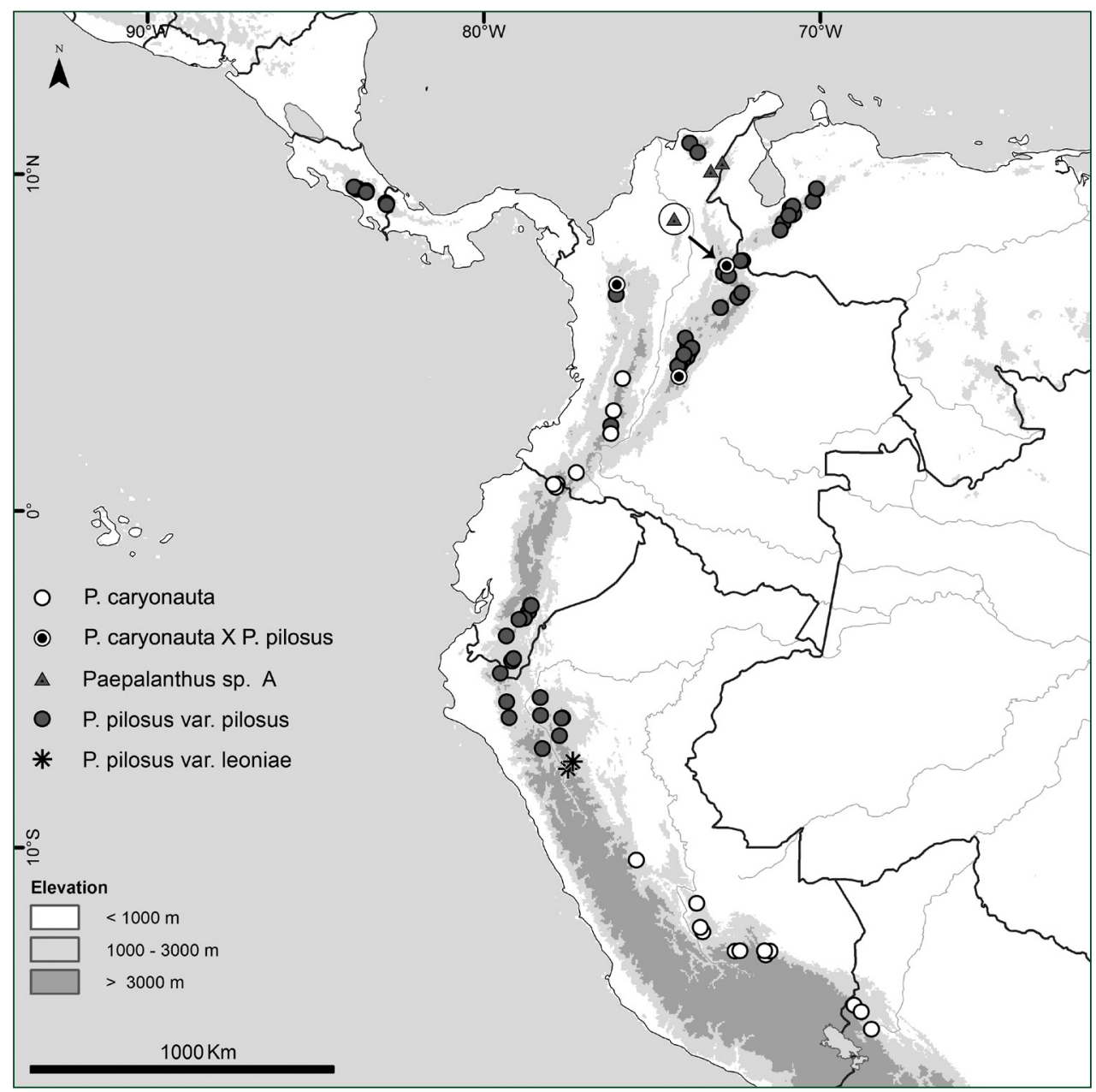

Figure 6. Distribution of Paepalanthus caryonauta and suspected hybrids, P. pilosus var. pilosus, P. pilosus var. leoniae, and Paepalanthus "Species A."

Cano 3873a (USM [photo]); Acjanaco, Cerro Macho Cruz, 3450 m, 30 Aug 1990, Cano 4024 (F,USM n.v.), 3400-3450 m, 2 Mar 1991, Cano 4465 (F p.p., USM [photo] p.p., mixed with $P$. dendroides); de El Mirador a Cerro Macho Cruz, 3500-3600 m, 21 Jul 1990, León \& Young 2245 (F,USM); Cerro Macho Cruz, 3 Sep 1990, León \& Young 2431 (USM [photo]); Tres Cruces, 4 Apr 1987, Núnez 7773 (F p.p., USM p.p., mixed with $P$. dendroides); Paso de Tres Cruces, Cerro de Cusilluyoc, 3800-3900 m, 3 May 1925, Pennell 13864 (F). Junín/Cuzco: Prov. Satipo/La Convencion, Cordillera Vilcabamba, Río Ene slope, 11³9'36"S, 7340'02"W, 3350-3400 m, 8 Jun 1997, Boyle et al. 4219 (F, USM). Pasco: Prov. Oxapampa, Distr. Huancabamba, Parque Nac. Yanachaga-Chemillen, Abra Yanachaga, 10²2'49"S, 7527'42"W, 2940 m, 2 Dec 2007, Monteagudo et al. 16143 (F,MO n.v.,USM n.v.). BOLIVIA. La Paz: 
Franz Tamayo, Parque Nac. Madidi, entre Queara y Mojos, Calistía, 1441'26"S, 68 59'44"W, 3600 m, 25 Feb 2008, Fuentes et al. 12018 (MO); Bautista Saavedra, Apolobamba, sector Codo, 1453'06"S, 6846'35"W, 3274 m, 28 Mar 2009, Fuentes \& Huaylla 13574 (F,MO); Cocopunco, 10,000 ft, 24 Mar 1926, G.H. Tate 382 (NY); Tolapampa, 10,000 ft, 11 Sep 1901, R.S. Williams 842 (F, NY).

Atypical specimens (not paratypes). Intermediates with $P$. pilosus: COLOMBIA. Antioquia: Paramo de Frontino, near Llano Grande, 3450 m, 27 Oct 1976, Boeke 269 (MO), Urrao, Paramo de Frontino, camino que va del Morro al Quince, $3450 \mathrm{~m}, 11$ Sep 1986, Roldán et al. 402 (MO). Meta: Macizo Sumapaz entre Boqueron del Buque and Laguna del Nevado, 3600 m, 7 Jul 1981, Diaz-Piedrahita 2608 (COL n.v.,MO). Norte de Santander: Paramo de Santurban, 3300-3500 m, 27 Jul 1940, Cuatrecasas \& GarciaBarriga 10302 (F, see discussion). Intermediate with P. dendroides: PERU. Pasco: Dist. Huancabamba. Sector Santa Barbara, Parque Nacional Yanachaga-Chemillén, $10^{\circ} 12^{\prime} \mathrm{S}, 75^{\circ} 22^{\prime} \mathrm{W}, 3200-3250 \mathrm{~m}, 27 \mathrm{Jan}$ 2005, Monteagudo et al. 7938 (F,MO n.v.).

\section{Paepalanthus dendroides (Kunth in H.B.K.) Kunth}

Figs 2A, 3C-E, 7

Paepalanthus dendroides (Kunth in H.B.K.) Kunth, Enum. Pl. 3: 507. 1841.

Eriocaulon dendroides Kunth in H.B.K., Nov. Gen. Sp. (quarto ed.) 1: 251, t. 59, fig. 2. 1815 [1816].

Type: Colombia. Cundinamarca: "Crescit in frigidis montanae planitiei Bogotensis inter Suba et Suacha, alt. 1340 hex.," Jul 1801, Bonpland \& Humboldt s.n. (lectotype, here designated: B [B 10 0243900]; syntypes: B [B-W 2366], HAL [HAL 0109752], P [P01762723]).

Paepalanthus barkleyi Moldenke, Phytologia 3: 114. 1949. Syn. nov.

Type: Colombia. Antioquia: $1 \mathrm{~km} \mathrm{~N}$ of Santa Rosa de Osos, 2600 m, 25 Sep 1948, S. Posada S., M. Torregrosa \& F. Barkley $18 A 100$ (holotype: NY; isotypes: COL [COL000006903], CORD [CORD00002162], LIL [LIL000143], US [US00088317]).

Paepalanthus karstenii var. corei Moldenke, Phytologia 29: 386. 1975. Syn. nov.

Type: Colombia. Cauca: Above Purace, 11,000 ft, 19 Feb 1944, E. L. Core 272a (holotype: NY; isotypes: W n.v., WVA n.v.)

Paepalanthus karstenii f. corei (Moldenke) Moldenke. Phytologia 45: 296. 1980. Syn. nov. Type: Based on P. karstenii var. corei Moldenke.

Type. Based on Eriocaulon dendroides Kunth in H.B.K.

Description. Plants terrestrial or partly submerged, forming densely leafy cushions or mats reported up to $30 \mathrm{~cm}$ in diameter (Fassett 25929), the erect branchlets ca. 1-5 $\mathrm{cm}$. Leaves linear-subulate, $9-22 \mathrm{~mm}$ long $\times 0.85-1.6 \mathrm{~mm}$ wide, tip cuspidate-acute, persistently pilose to hirsutulous adaxially with white roughened hairs, sometimes nearly glabrous (Peru, Cajamarca and Pasco), mostly eciliate, consistently paler green than 
P. caryonauta or $P$. pilosus, with veins slightly salient below. Peduncles $20-130 \mathrm{~mm}$ long, pale, rigidulous (Peru) or often soft and compressible and then noticeably constricted at apex when dry, glabrous except for an apical collar of sericeous appressed hairs; peduncle sheaths $13-23 \mathrm{~mm}$ long, tightly enclosing the peduncle, equaling or scarcely exsert from leaf mat, tufted at apex otherwise mostly glabrous. Capitula $3.5-5 \mathrm{~mm}$ wide. Involucral bracts about equaling flowers, ovate, similar to $P$. caryonauta but the outer bracts more hyaline, paler, sometimes uniformly gold and glabrous except at margins. Trichomes of bract and sepal apices obtuse to clavate, strongly tuberculate. Flowers ca. 12-17 per capitulum, pistillate peripheral, the staminate equaling to subequaling the pistillate in number. Pistillate flowers: Pedicels ca. $0.25-0.45 \mathrm{~mm}$ long, fine, not thickened at maturity. Sepals obovate-spatulate, $1.15-1.85 \mathrm{~mm}$ long $\times 0.65-0.85 \mathrm{~mm}$ wide, $0.15-0.25 \mathrm{~mm}$ wide at base, blackish-brown, short-ciliate along upper margin and bearded with longer appressed hairs on upper dorsum, the basal half of the midrib hygroscopically thickened, and spadiceous-brown in fruit, the broad distal half of the sepal remaining chartaceous, suberect, detaching from diaspore upon dispersal. Petals broadly spatulate, $1.15-1.75 \mathrm{~mm}$ long, $0.55-1.0 \mathrm{~mm}$ wide, ca. 1.6-2.3 times longer than wide, cream-colored and densely long-pilose with tuberculate trichomes on the abaxial surface flanking the midvein, not thickening, dispersed with fruit. Gynoecium with style base 0.15-0.25 $\mathrm{mm}$ long, the nectaries 0.55-0.7 $(-0.85) \mathrm{mm}$ long, the glandular portion colorless to pale pink to red- or yellow-brown, penicillate, slightly curved after anthesis, the apical ring of papillae colorless (white), thin- to thick-walled; styles $0.75-0.9 \mathrm{~mm}$, mostly thinner and less pigmented than in $P$. pilosus or $P$. caryonauta. Seeds $0.6-0.75$ $\mathrm{mm}$ long, orange-brown, the pseudotrichomes weak, erect upon wetting but collapsing soon after (few seeds observed). Staminate flowers: Pedicels (0.35-) 0.4-0.6 mm long, fine, membranous, nearly glabrous. Sepals $1.1-1.9 \mathrm{~mm}$ long $\times 0.35-0.5 \mathrm{~mm}$ wide, narrowed to base and very shallowly fused or if fused up to half the sepal length, not thickening, the calyx base not obconic at maturity, color and pubescence as in pistillate flowers. Corolla (1.0-) 1.4-1.7 (-1.95) mm long; the anthophore alone (0.35-) 0.55-0.95 $\mathrm{mm}$ long, comprising ca. $40-60 \%$ of the corolla length, membranous and ca. $0.1-0.2$ $\mathrm{mm}$ in diameter at base, $0.3 \mathrm{~mm}$ at apex, the lobed tube (0.55-) 0.65-0.9 $(-1.0) \mathrm{mm}$ long. Filaments often unpigmented, slightly less exsert than in $P$. caryonauta, the base of the anther rarely exsert more than $0.3 \mathrm{~mm}$ beyond lobe tips. Nectaries well-included within tube, usually only half-equaling the sinuses.

Phenology. In Central America, flowering from March to April, in the dry season, and from August to September, the wet season, punctuated by a short dry period or veranillo (Grayum et al. 2004). In Antioquia, Colombia, collected mostly in rainy season from April to September. Elsewhere in Colombia, from July to February. In Peru, collected in anthesis from January to May (Cuzco, Pasco; wet season), and in August (Cajamarca, Huanuco; dry season); in post-anthesis from March to November.

Distribution. Costa Rica (Cerro de Talamanca): Limón, Puntarenas. Panama: Bocas del Toro. Colombia (Central and Eastern Cordilleras): Antioquia, Bogotá D.C., Boyacá, Cauca, Cundinamarca, Nariño, Santander, Norte de Santander. Peru: Cajamarca, Cuzco, Huánuco, Pasco, Puno. Brazil (Pico da Neblina): Amazonas. (Fig. 8). 


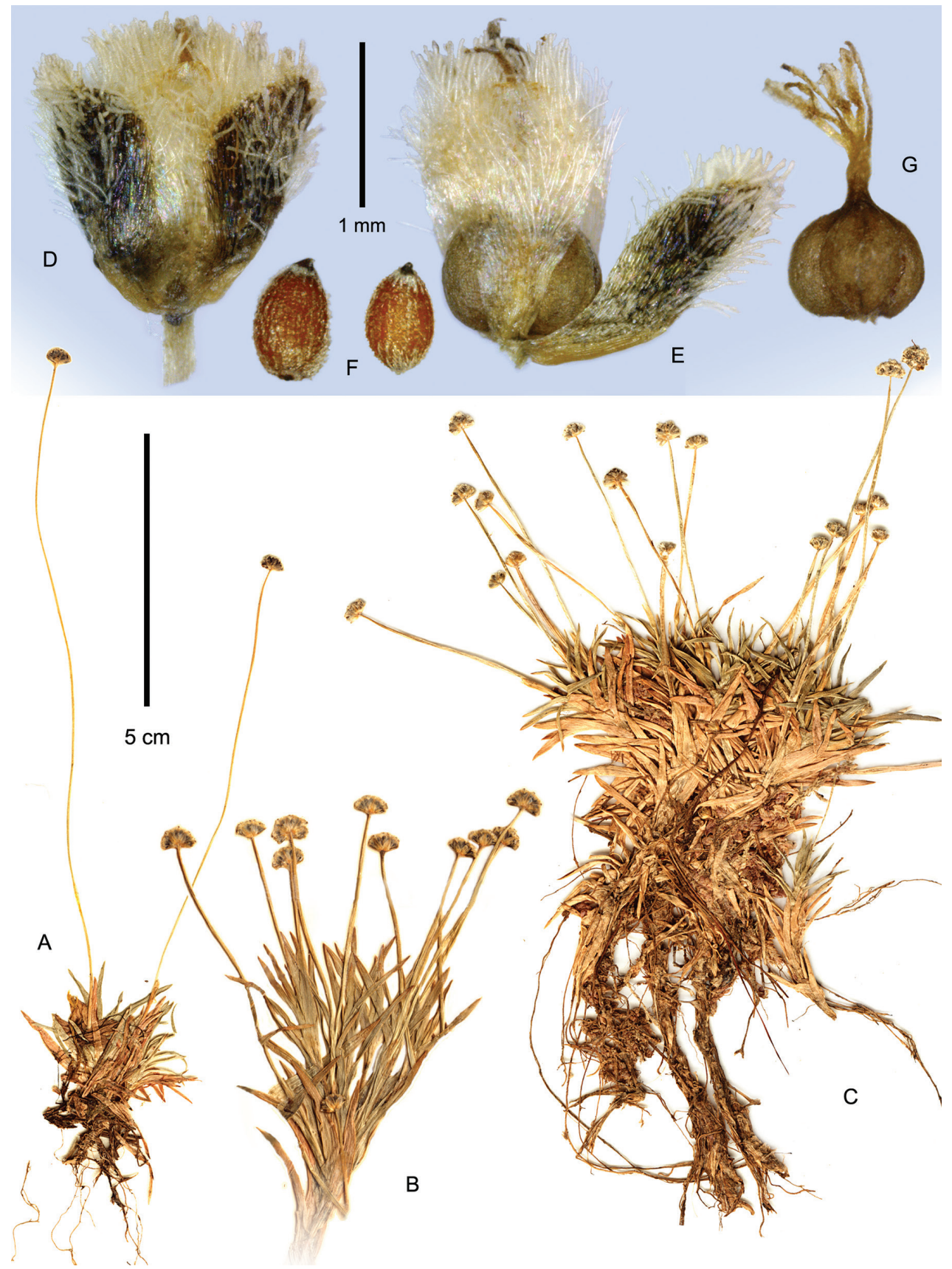

Figure 7. Paepalanthus dendroides. A-C Habit (A Núñez 7773 B Cuatrecasas 23654 C Davidse 28991) D-F Pistillate flower in fruit (Pennell 13866) D Whole flower E Diaspore with two sepals removed F Seeds G Gynoecium of young fruit (Luteyn 10737). 
Habitat and ecology. A terrestrial or partly submerged aquatic, in open marshy subparamo, low paramo or cloud forest margins, in bogs, wet meadows, seeps, commonly associated with Sphagnum or tussock grasses, sometimes shrubs or Blechnum. Elevation mostly 2300-3200 m, but as low as $1900 \mathrm{~m}$ in Antioquia, and up to 3800 $\mathrm{m}$ in Cuzco (Abra Acjanaco), Peru. In the high elevation Cuzco plants seed production does not appear abundant, abortive flowers are common, and smut fungus infection is observed.

Conservation status. The conservation status of this widespread species is presumed to be of Least Concern (IUCN 2014). However it may have recently disappeared from the disturbed paramos near Bogotá, where it hasn't been collected since 1917. Its lower elevation of occurrence and semi-aquatic habit may make it more vulnerable than its relatives to habitat loss due to disturbance.

Taxonomic history. Paepalanthus dendroides was initially described by Kunth and later Körnicke (1863) as having unbranched stems with leaves clustered toward the apex and peduncles "umbellate" or in terminal fascicles, a misinterpretation likely due to the small size of the specimens. In addition, Kunth described both P. pilosus and $P$. dendroides as having bifid stigmas; his sketch of the gynoecium of $P$. dendroides is mounted on the lectotype sheet. The published plate shows only 3 bifid stigmas, while the sketch shows three presumed filiform "appendages," alternating with three thick shallowly bifid "stigmas." Körnicke (1863) later corrected the description of P. pilosus to "stigmas simple" but accepted without comment the bifid stigmas of $P$. dendroides. I have only seen a scan of the type, which clearly corresponds to $P$. dendroides as here treated, and can only assume Kunth either misinterpreted the gynoecial structure as he had done for $P$. pilosus, or examined an abnormal flower. There are no species in this alliance or among any Andean Paepalanthus of similar habit, which have normally bifid stigmas.

Paepalanthus dendroides was placed in synonymy of P. pilosus by Ruhland (1903), but the specialist Harold Moldenke (fl. 1930's-1980's) generally distinguished the two species in his annotation work, misapplying the name $P$. pilosus to $P$. dendroides and to lax long-pedunculate specimens of $P$. pilosus, while using the name $P$. karstenii for most material of $P$. pilosus. (See detailed discussion under $P$. pilosus.) The name $P$. dendroides was removed from synonymy and its identity clarified by Hensold and Hammel (2003), but is still commonly used for long-pedunculate plants of $P$. pilosus (cf. Madriñán and Zapata 2001).

Misapplied name. Paepalanthus pilosus sensu Ruhland (1903) in part, Moldenke (1953, 1975c, 1979, 1983) in part, Brako and Hensold (1993) in part, Huft (1994), Santa Cruz (2011), non (Kunth in H.B.K.) Kunth.

Discussion. Paepalanthus dendroides is a variable species across its range, but may be distinguished from its close relatives by the character syndrome in Table 1 . The broadly spatulate and densely pilose petals which enfold the diaspore, together with reduced pigmentation of the gynoecia, filaments and seeds, are characteristic. The subaquatic habit and the lower elevation range are distinctive as well. It tends to have a less congested habit and softer leaves than its relatives, but also may form compact, stiff- 


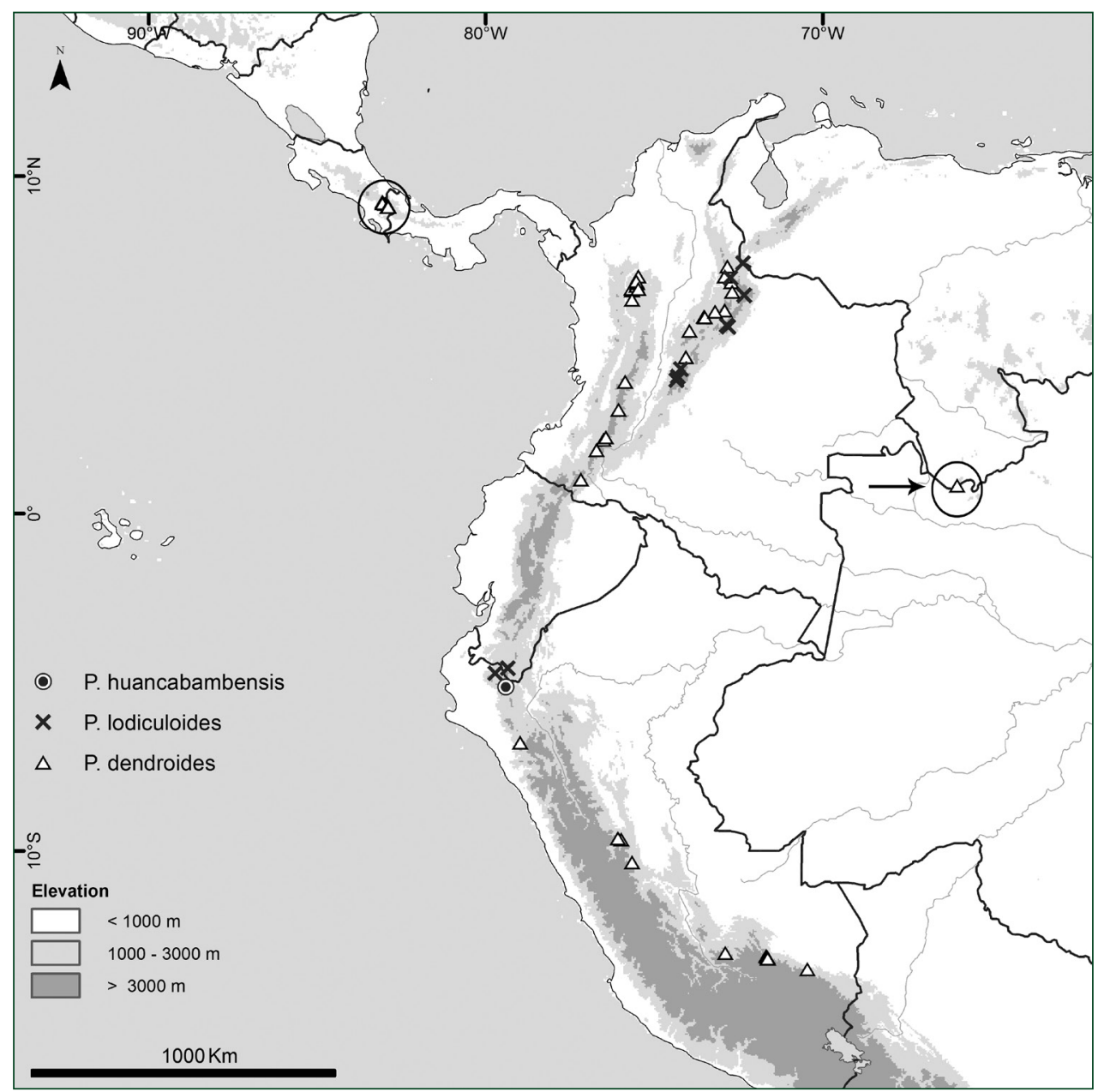

Figure 8. Distribution of Paepalanthus dendroides, P. huancabambensis, and P. lodiculoides.

leaved cushions with dwarf peduncles on some sites, as in the type of $P$. karstenii var. corei, and then floral characters may be important for identification. It should be noted that key characters useful for Costa Rican material (Hensold and Hammel 2003) do not consistently apply in South America, including the pale-striped sepal midlines, the constricted peduncle apex, and the dorsally glabrous involucral bracts. These characters are variable in Colombia and rare in Peru.

Of the Peruvian collections, those from Huánuco, Cuzco, and Puno share a similar morphology, with leaves relatively narrow and conspicuously pilose above, the outer involucral bracts dusky gray, and the nectaries somewhat pigmented. Leaf pubescence easily distinguishes these populations from sympatric $P$. caryonauta. In comparison, specimens from Cajamarca and Pasco have broader, glabrous leaves. The Cajamarca collections were examined only from photos, but the plants closely match Colombian 
material of $P$. dendroides and are from a similar habitat and elevation. The Pasco collection (Vasquez 29038) has floral characters somewhat intermediate with $P$. pilosus or $P$. caryonauta, as follows: petals 2.0-2.3(-3.0) times longer than wide; style base 0.4-0.5 $\mathrm{mm}$; nectaries darker, $0.85-0.95 \mathrm{~mm}$ long; styles to $1.0 \mathrm{~mm}$ long; nectaries of male flowers almost reaching the mouth of the corolla.

Evidence of hybridization. The Pasco, Peru, specimen (Vásquez 29038) was collected very near a plant fully intermediate between it and $P$. caryonauta, with abortive locules and stigmas (Monteagudo 7938; full specimen citation under P. caryonauta). Typical P. caryonauta (Monteagudo et al. 16143) is recorded $20 \mathrm{~km}$ to the east.

In Colombia, introgression between $P$. dendroides and $P$. pilosus is suspected in the disturbed paramos east of Bogotá. Although $P$. dendroides was originally described from near Bogotá, I have only seen one other typical individual from this vicinity (Pennell 1997), collected at Quebrada Chapinero in 1917, the same locality where the type of P. schultesii (=P. pilosus) was collected in 1941. Paepalanthus pilosus is presently abundant near Bogotá, but seems particularly variable and with an unusual tendency to long peduncles, lax habit, and variably shaped bracts, suggesting intermediacy with $P$. dendroides (see $P$. pilosus discussion). Typical $P$. dendroides is currently found north of Bogotá, where it is mostly recorded from elevations 500-900 m lower than nearby collections of $P$. pilosus. In Panamá, however, typical $P$. dendroides and $P$. pilosus are sympatric at the Cerro Fabrega massif, without apparent intermediates.

Selected specimens examined (of 56 total). COSTA RICA. Limón: Cerro Kamuk, 9¹4'30"-15'30"N, 8303'30"-04'30"W, 2900-3100 m, 23-26 Mar 1984, Davidse et al. 25928 (F,MO); Atlantic slope, between Rio Terbi and Rio Siní, $9^{\circ} 00^{\prime}-9^{\circ} 12^{\prime} \mathrm{N}, 82^{\circ} 58^{\prime}-82^{\circ} 59^{\prime} \mathrm{W}, 2400-2750 \mathrm{~m}, 13$ Sep 1984, Davidse et al. 28991 (F,MO). Limón/Puntarenas: Cerro Kasir, 9²12'N, 8303'30"W, 2950 m, 22 Mar 1984, Davidse \& Herrera 29339 (F,MO). PANAMA. Bocas del Toro: [Fabrega Massif], S of Cerro Itamut, 905'40"N, 8253'06"W, 3200 m, 17 Mar 2006, Monro \& Knapp 5369 (MO). COLOMBIA. Antioquia: Mpio. Belmira, Finca El Paramo, 3000-3130 m, 29 Jan 1995, Fonnegra et al. 5408 (F); N of Las Ventanas, 0702 'N, 75 30'W, 1730-1920 m, 26 May 1984, Luteyn et al. 10737 (F); Yarumal, Llanos de Cuivá, 06 $50^{\prime} \mathrm{N}, 7^{\circ} 30^{\prime} \mathrm{W}, 2700$ m, 27 Jul 1986, Roldán 252 (MO); Bello, Vereda San Felix, 06 $21^{\prime} \mathrm{N}, 7^{\circ} 39^{\prime} \mathrm{W}, 3050$ m, 7 May 1988, Zarucchi \& Echeverri 6332 (MO); Bogotá, D.C.: Chapinero, 2700-2800 m, 18-23 Sep 1917, Pennell $1997(\mathrm{~F})$; Boyacá: Belen, Huina, 7 May 1959, Barclay 7629 (MO); 14 km NW of Arcabuco, 2440 m, 20 Aug 1944, Fassett 25629 (MO), Mpio. Chiscas, sector Duartes Arriba, 2850 m, 8 Jul 2003, Galindo-T. et al. 1303 (COL [COL000057819]); Cauca: Valencia, 3090 m, 24 Sep 1958, H. G. Barclay 5730 (MO); Cordillera Central, E slope [probably valley of Rio San José, Moscoso], 2980-3000 m, 2 Feb 1947, Cuatrecasas 23654 (F); Paramo de Paletará, 3000 m, 18 Nov 1968, Espinal \& Ramos 3310 (MO); Cundinamarca: Pántanos de Fúquene, 2600 m, Mar 1930, Pérez-Arbeláez 66 (COL [COL 000223800]); Narińo: Putumayo, Paramo de Santa Lucia, 2900-3100 m, 9 Jan 1941, Cuatrecasas 11866 (F); Santander: N of Cerrito, 3200 m, 12 Oct 1944, Fassett 25929 (MO); Las Vegas, 2600-3000 m, 21- 23 Dec 1926, Killip \& Smith 
16064 (F); 11 km NE of Berlin, 3330 m, 18 Jul 1979, Stuessy \& Funk 5612 (MICH); Santander/Norte de Santander: Paramo de la Laguna, between Pamplona and Bucaramanga, 2900 m, 26 Feb 1939, A. H. G. Alston 7333 (F). BRAZIL. Amazonas: Pico da Neblina, 2700 m, 21 Aug 1985, C. Farney \& Pessoal do $1^{\circ}$ B.F.E. 901 (RB) PERU. Cajamarca: Prov. Santa Cruz, Distr. de Pulán, El Progreso, 2700 m, 5 Aug 2006, L. Santa Cruz 653 (USM [photo]). Cuzco: Prov. Paucartambo, Parque Nac. del Manú, Acjanaco, 3400-3500 m, 3 May 1990, Cano 3361 (F), 2 Mar 1991, Cano 4437 (F), 3500-3600 m, 21 Jul 1990, León 2243 (F); Trocha Acjanaco - Macho Cruz, 3350 m, 2 Mar 1991, León \& Huapaya 2683 (F,USM[photo]); Paso de Tres Cruces, Cerro de Cusilluyoc, 3800-3900 m, 9 May 1925, Pennell 13866 (F); Prov. La Convención, Distr. Santa Ana, Pavayoc, 2600 m, 14 Mar 1953, Woytkowski 567 (USM [photo]). Huánuco: [probably "Saxiapata, in the montana of Pillao and Chacahuasi, "Aug-Sept 1787], Ruiz \& Pavón s.n. (MO 1612102); Villcabamba, Hacienda on Rio Chinchao, 6,000 ft, 17-26 July 1923, Macbride 5182 (F). Pasco: Prov. Oxapampa, Dist. Huancabamba, Santa Barbara, 10²0'35"S, 75³9'00"W, 3400-3500 m, 25 Jan 2004, Vásquez et al. 29038 (F,MO,USM). Puno: [Prov. Carabaya, San Gaban], "in summis Cordiller. jugis pr. San Govan," Jul 1854, Lechler in Pl. peruv., ed. Hohenacker 2206 (P [P01762726]).

\section{Paepalanthus huancabambensis Hensold, sp. nov.} urn:Isid:ipni.org:names:77155458-1

Figures 3F, 9

Diagnosis. Plants forming loose cushions or mats; leaves blue-green, pilose above, older leaves strongly costate below; peduncle sheaths $25-30 \mathrm{~mm}$, very lax, and strongly exsert from the leaf mat, the involucral bracts dark brown, the heads with over 20 flowers; pistillate flower petals spatulate, pilose; nectaries dark red-brown and rigidulous, those of the male flowers equaling the corolla sinuses.

Type. PERU. Piura: Huancabamba, Jalca de Chiguelas, 5⒏2'S, 79²3.6'W, $3082 \mathrm{~m}$, 19 Oct 2001, A. Sagástegui et al. 16799 (holotype: F; isotype: HAO).

Description. Plants short-caulescent, with erect actively growing shoots to $4 \mathrm{~cm}$, densely leafy, branching to form rounded mats. Leaves subulate, acute, $13-22 \mathrm{~mm}$ long $\times 1-2 \mathrm{~mm}$ wide at midpoint, tip cuspidate to apiculate, densely pilose to villous above with appressed to spreading white tuberculate hairs, upper margin eciliate, lamina dark blue-green, mature leaves prominently 3-5-costate below. Inflorescences solitary and terminal, soon overtopped by one or two erect lateral shoots which may flower in rapid succession, so that peduncles superficially appear fascicled. Peduncles $6.0-11.5 \mathrm{~cm}$ long at anthesis, perhaps continuing to elongate into fruiting, with peduncle of previous season up to $15 \mathrm{~cm}$ observed on same plant, ca. 3-costate, densely subappressed-villous especially above, with a dense sericeous collar of trichomes subtending involucre. Peduncle sheaths $25-30 \mathrm{~mm}$, much surpassing the leaves, and strongly surpassing the leaf mat, scarious, very lax, nearly glabrous except for the 

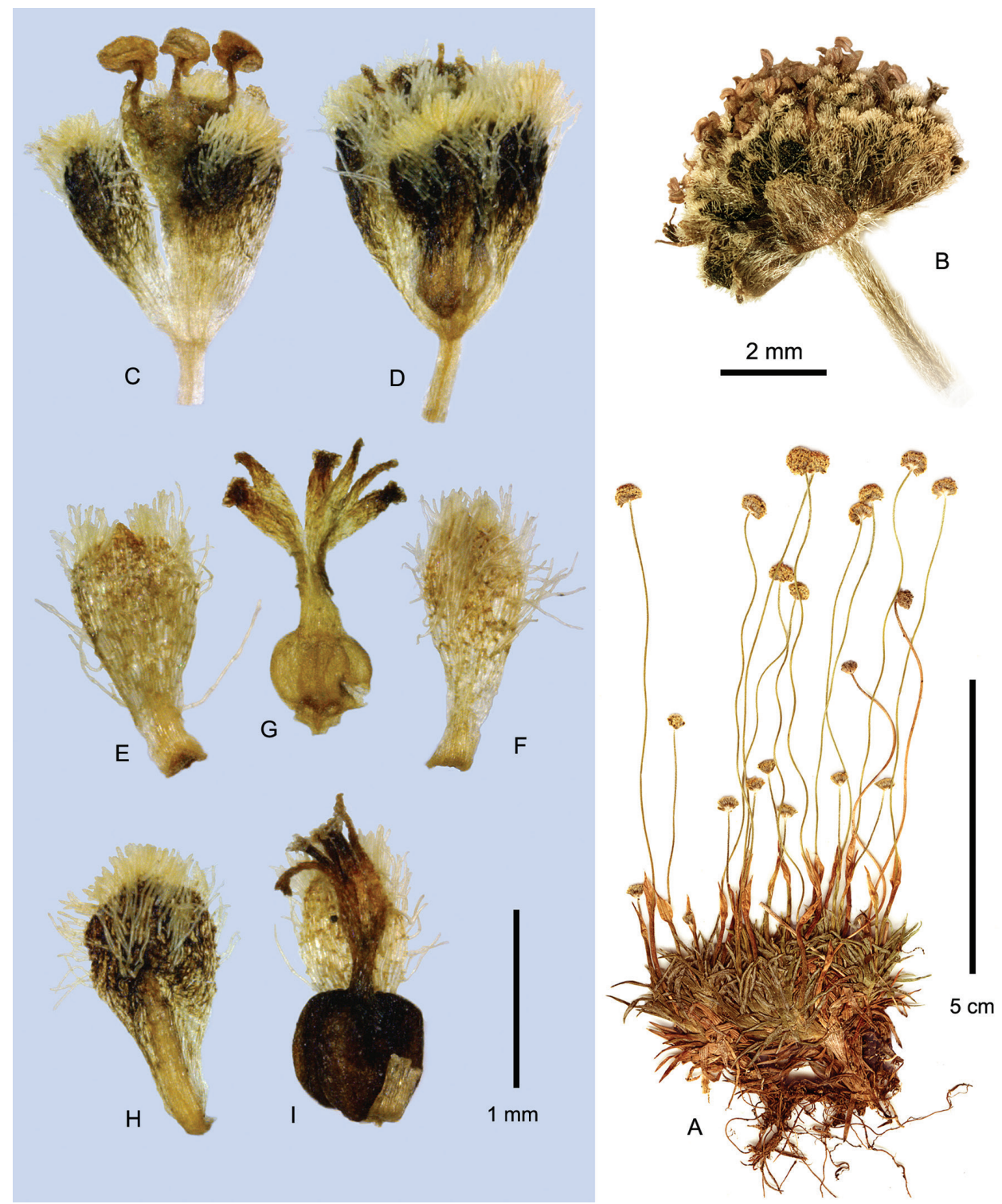

Figure 9. Paepalanthus huancabambensis (Sagástegui 16799). A Habit B Capitulum, anthesis C Staminate flower, anthesis D-I Pistillate flower D Whole flower E Petal, adaxial F Petal, abaxial G Gynoecium, juvenile $\mathbf{H}$ Sepal, anthesis I Gynoecium and one petal, young fruit.

tufted apex, the lamina cucullate, enclosing the bud when young and then splitting broadly into two or three triangular segments. Capitula $4-6 \mathrm{~mm}$, depressed-hemispheric. Involucres subequaling flowers at anthesis, and opening broadly at maturity; involucral bracts 2-3-seriate, the outer bracts triangular-ovate, greenish to uniformly dark brown, shaggy-ciliate on margins and villous in two submedial bands. Floral 
trichomes obtuse to clavate, strongly tuberculate. Flowers ca. 20-24 per capitulum, the pistillate flowers peripheral, the staminate central, with 14-18 pistillate flowers to 6 staminate flowers (in two capitula sampled). Receptacle sparingly long-pilose with brownish hairs. Receptacular bracts subequaling flowers, linear-subspatulate, the apex slightly cucullate, pubescent as sepals, the base sharply carinate. Pistillate flowers: Pedicels $0.3-0.45 \mathrm{~mm}$ long, fine and membranous. Sepals broadly obovate-spatulate to subtruncate at apex, sometimes weakly cymbiform, $1.55-1.65 \mathrm{~mm}$ long $\times 0.65-$ $0.8 \mathrm{~mm}$ wide at middle, $0.15-0.2 \mathrm{~mm}$ wide at base, blackish-brown, short-ciliate (apical cilia to $0.17 \mathrm{~mm}$ ) along upper margin, and appressed-long-pilose in two bands flanking the upper dorsum, the basal half of the midrib hygroscopically thickened, spadiceous-brown in fruit, and recurving when dry, the broad upper half of the sepal remaining chartaceous, erect; sepals detaching from fruit on dispersal. Petals spatulate, obtuse, brownish at tip, $1.25-1.35 \mathrm{~mm}$ long, the widest in a flower ca. $0.65 \mathrm{~mm}$ wide, ca. 2.2 times longer than wide, bearing scale-like staminodes at base, densely long-pilose with long tuberculate hairs on abaxial upper half except for midvein, also tufted subapically within, the hairs enfolding the style branch, petals not thickening in fruit, dispersed with fruit. Gynoecium with style base $0.35 \mathrm{~mm}$ long; nectaries ca. $0.7 \mathrm{~mm}$ long, dark red-brown, penicillate to subclavate-infundibular, with fringe of colorless stiff-walled papillae at mouth, these rigidulous and maintaining shape after anthesis; style branches $0.85 \mathrm{~mm}$ long, thick and dark red-brown, non-involute. Only two slightly misshapen seeds seen, $0.6-0.63 \mathrm{~mm}$ long, pinkish to red-brown, the pseudotrichomes weak. Staminate flowers: Pedicels $0.35-0.4 \mathrm{~mm}$, membranous, nearly glabrous. Sepals $1.6-1.7 \mathrm{~mm} \times 0.5-0.6 \mathrm{~mm}$, spatulate to obrhombic or subtruncate, color and pubescence as in the female flowers, narrowed toward base and shallowly fused. Corolla $1.8 \mathrm{~mm}$ long; the anthophore $1.15 \mathrm{~mm}$ long, comprising ca. $65 \%$ the length of the corolla, grading from $0.15 \mathrm{~mm}$ wide at base to $0.35 \mathrm{~mm}$ wide at apex; the tube $0.65 \mathrm{~mm}$ long including well-defined brownish-tinged lobes. Filaments brownish-tinged above; exsert not more than $0.3 \mathrm{~mm}$ beyond lobe tips, anthers persistent, cream to light brownish. Nectaries equaling corolla sinuses.

Phenology. Collected in flower May, September, October.

Distribution. Endemic to Peru, Piura, Cordillera de Huancabamba, District Carmen de la Frontera (Fig. 8).

Habitat. Grass páramo (or jalca), probably of anthropic origin, and "burnt cloud forest, growing under Pteridium aquilinum" (Weigend \& Dostert 98/252). Elevation ca. $2900-3000 \mathrm{~m}$.

Conservation status. Assessed as Critically Endangered, according to IUCN Criteria B1ab(iii) (IUCN 2014). Known from one locality in an unprotected area subject to deforestation, subsistence agriculture, and tourism.

Notes. Paepalanthus huancabambensis is similar in habit and dimensions to $P$. dendroides, but differs by its very lax, elongate peduncle sheaths well exsert from the leaf mat, and the large capitula with more flowers. It also differs in the dark blue-green leaf color, compared to the consistently pale green leaves of the widespread $P$. dendroides, and preliminary anatomical study distinguishes it from that species by the presence of 
adaxial vein buttresses (bundle sheath extensions) in leaf median section. The broadly spatulate densely pilose female petals are similar to those of $P$. dendroides. However, the longer style base, the dark rigidulous nectaries with stiff colorless papillae fringing the rim, and the size of the nectaries relative to the corolla tube in the male flowers all suggest $P$. pilosus.

Except for the lax peduncle sheaths, this species lacks any strong distinctive features of its own but its mixture of critical characters prevent it from being easily placed in any related species, and do not immediately suggest hybrid origin. It is endemic to the Cordillera de Huancabamba near the border of Peru and Ecuador in the western part of the Andean chain. Notably, in the same vicinity are also found an atypical form of $P$. pilosus (Cano 16840, discussed under P. pilosus var. pilosus), and at higher elevations the only known populations of $P$. lodiculoides from Peru and Ecuador.

Additional specimens examined. PERU. Piura: Huancabamba, Cordillera Chinguela (Sapalache el Cármen), 2900 m, 15 Sept 1981, Sagástegui et al. 10225 (HUT n.v., MO), Huancabamba-Sapalache, waterfall E of Chorro Blanco E of Sapalache, growing under Pteridium aquilinum in burnt cloud forest, 2650-2930 m, 19 May 1998, Weigend \& Dostert 98/252 (M, USM n.v.)

\section{Paepalanthus lodiculoides Moldenke}

Figs 2E, 10

Paepalanthus lodiculoides Moldenke, Bull. Torrey Bot. Club 68: 68. 1941 [31 Dec 1940]. Syngonanthus steyermarkii Moldenke, Phytologia 2: 418. 1948.

Type: Venezuela. Táchira: Páramo de Tamá, near Venezuelan-Colombian border, 3045-3475 m, 15 July 1944, J. Steyermark 57372 (holotype: NY [NY00103700]; isotype: F).

Paepalanthus polytrichoides var. densus Moldenke, Phytologia 8: 392. 1962.

Type: Colombia. Cundinamarca: Paramo de Chisacá, around Laguna de Chisacá, 3650-3700 m, 29 Dec 1959, J. Cuatrecasas \& R. Jaramillo M. 25737 (holotype: LL; isotypes: COL [COL000006924], US [US00088389]).

Paepalanthus lodiculoides var. floccosus Moldenke, Phytologia 32: 47.1975.

Type: Colombia. Boyacá: Paramo de la Sarna, entre Sogamoso y Vado Hondo, 5

$\mathrm{km}$ al NE de la Laguna de Tota, 3510 m, 30 Mar 1973, A. Cleef et al. 9214 (holotype: COL [COL000006910]; isotype: LL, U [U0007809], US [US00088365]).

Type. Colombia. Boyacá: Nevado de Cocuy, Alto Valle de las Lagunillas, $4000 \mathrm{~m}$, 12 Sept 1938, J. Cuatrecasas \& H.García Barriga 1537 (holotype: US [US00088366]; isotypes: BC [BC638454], COL [COL000006909], F, NY [NY00102897], P [P00741963]).

Description. Plants compact densely branched mosslike cushions, reportedly up to $23 \mathrm{~cm}$ in diameter (Soderstrom 1262) and $2 \mathrm{~cm}$ high (Pedraza-Peñalosa et al. 2005). Leaves 1.7-5 (-6.5) $\mathrm{mm}$ long including broad basal sheath, the sheath often com- 


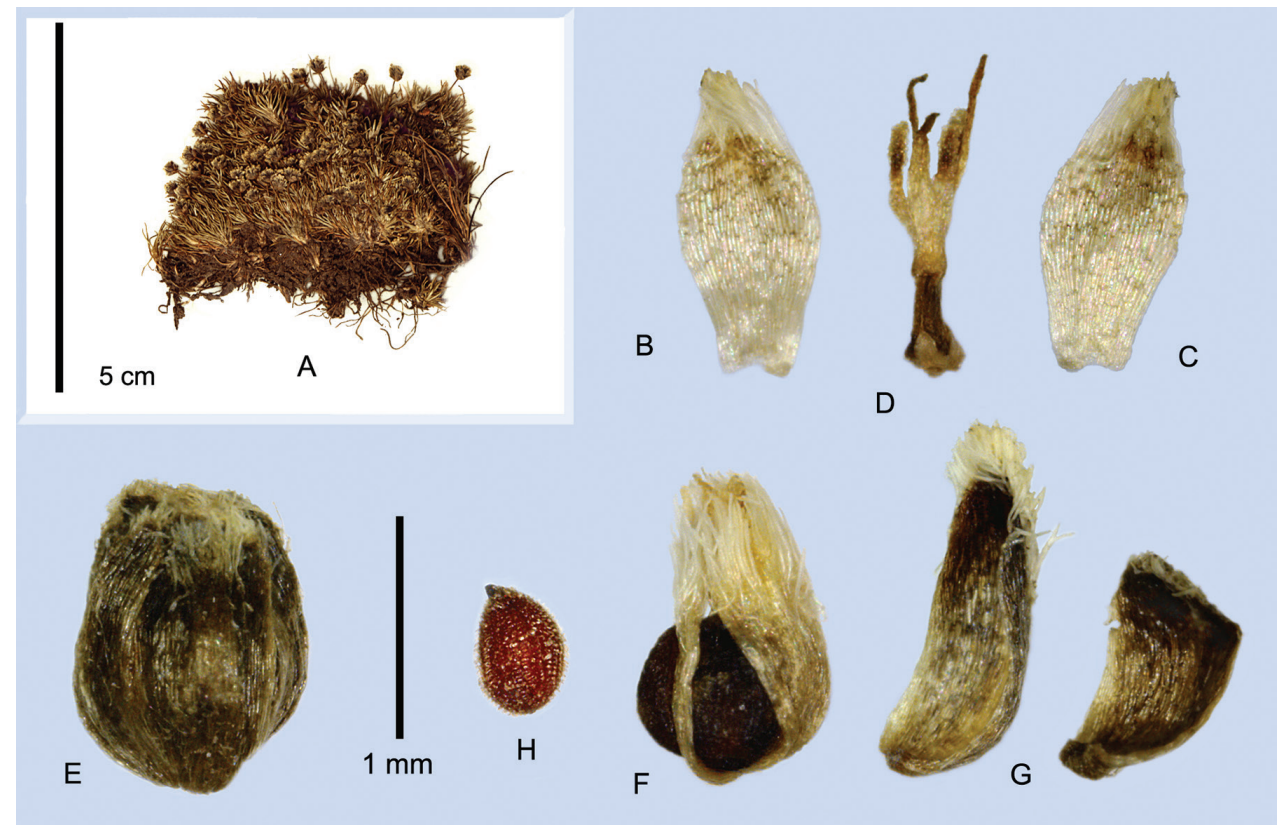

Figure 10. Paepalanthus lodiculoides. A Habit B-H Pistillate flower and fruit B Petal, adaxial C Petal, abaxial D Gynoecium (ovary abortive, atypical.) E Mature diaspore F-G Diaspore (F) with sepals removed (G) H Seed. (A Cuatrecasas 25987 B-D Barclay 6113 E-G Øllgaard 9717 H Steyermark 57372)

prising half or more of the leaf length, the lamina subulate, dark to pale green, ca. $0.25-0.35 \mathrm{~mm}$ wide in the middle when mature, apex sharply acute (Loja) to subacute or minutely rounded; leaves densely congested along the short stems, and often half buried in deep woolly pubescence of the stem and lower leaf cilia, the tips glabrous. Peduncles (2-) 5-11 mm long, usually exsert $1 \mathrm{~mm}$ or more from sheaths and leaf mat at anthesis, obscurely 3 -costate and often scurfy-pilose in lower half, rigid, subterete, and glabrous at apex. Peduncle sheaths (1.7-) 3-5 mm long, with an oblique scarious, sharp-acuminate to irregular or bifid apex, glabrous or obscurely tufted apically, margins eciliate (but cf. S. steyermarkii type, see below). Capitula (1.4-) $2.5-3 \mathrm{~mm}$ in diameter. Involucres about equaling flowers; involucral bracts ovate to orbicularovate, dark black-brown throughout or paler brown along midvein, tufted at apex with clavate to linear, smooth to slightly tuberculate trichomes. Flowers ca. 4-6 per capitulum, sex ratio of capitula varying widely, from flowers all male to mostly female to some mixture of the two, even on same plant, the few flowers mostly peripheral, subtended by broad upper involucral bracts; receptacular bracts only rarely produced, these narrower and more oblong than involucral bracts, and carinate at base. Pistillate flowers: Pedicels sclerified, blackish, $0.1-0.15 \mathrm{~mm}$, persisting on receptacle as bumps. Sepals broadly elliptic to suborbicular, strongly rounded-cymbiform in fruit, 1.2-1.7 $\mathrm{mm}$ long by ca. $0.65 \mathrm{~mm}$ wide at middle, $0.35-0.45 \mathrm{~mm}$ wide at base, deep blackish brown, sometimes with a pale medial streak, tufted with trichomes at apex. Petals 
oblong-obovate to broadly spatulate, acute-erose to acuminate, $1.1-1.6 \mathrm{~mm} \times 0.4-0.7$ $\mathrm{mm}$, cream to nearly black, the distal half moderately pilose on both surfaces in two submedial or submarginal bands. Gynoecium at anthesis with ovary ca. $0.3 \mathrm{~mm}$, style column $0.3 \mathrm{~mm}$, nectaries ca. $0.35-0.6 \mathrm{~mm}$, the glandular portion about equaling the stalk, clavate, the papillae soft and membranous, concentrated at apex but scattered along outside, colorless or tinged orange-brown at base, style branches $0.7-0.9 \mathrm{~mm}$, brownish. Seeds $0.55-0.6 \mathrm{~mm}$ long, reticulate with short pseudotrichomes; locule wall thin, dehiscent or in some specimens observed adhering to the seeds, and the locules splitting apart without dehiscing (perhaps only in dry material). Staminate flowers: Pedicels $0.15-0.25 \mathrm{~mm}$, brown. Sepals broadly spatulate, blackish toward apex, tufted; corolla with narrow membranous anthophore and broad tube with acute to acuminate lobes; anthers cream, exsert; the nectaries only half-equaling the corolla sinuses.

Phenology. In Peru, flowering May-June (early in dry season); in Ecuador, September; in Colombia and Venezuela, July-Sept and Nov-March. Pedraza-Peñalosa et al. (2005) reports flowering times similar to P. pilosus at Chisaca, corresponding to the "little dry season."

Distribution. Colombia (Eastern Cordillera); Bogotá D.C., Boyacá, Cundinamarca, Santander. Venezuela (Paramo de Tamá): Táchira. Ecuador: Loja. Peru: Piura. This is the first report of the species from Peru. (Fig. 8)

Habitat. In paramo, at (3000-) 3300-4000 m. Cited by some authors as characteristic of very wet páramo of lake margins, bogs, and in grass paramo (Madrinán and Zapata 2001, Pedraza-Peñalosa et al. 2005). However Cleef (1981) reports P. lodiculoides var. floccosus from the "upper zone of atmospherically dry [bunchgrass] páramo," on the west side of the Eastern Cordillera, and the typical variety from "lower bamboo páramo" on atmospherically wet (east) slopes.

Conservation notes. Known from two disjunct bands of paramo, one $420 \mathrm{~km}$ long in the north, and one about $100 \mathrm{~km}$ long in the south, under cool wet conditions.

Discussion. Paepalanthus lodiculoides is easily distinguished from all other species in the group by the tiny moss-like leaves, delicate peduncles, and small capitula. The diaspores enclosed by persistent sepals and petals are similar to those of $P$. caryonauta. According to Madrinán and Zapata (2001) this species forms larger and more compact cushions than P. pilosus at Páramo Chingaza, Cundinamarca. Pedraza-Peñalosa et al. (2005) describe the cushions as less than $2 \mathrm{~cm}$ tall, or only about half as tall as those of sympatric $P$. pilosus ("P. karstenii"). The branch architecture is similar to the other species but the dense cushions are sometimes distinguished by the many soft, nearly upright stems tightly packed together, possibly on wetter sites. Other individuals have shorter, more rigid stems and shorter branchlets. There are also pronounced differences in the amount of stem pubescence and leaf coloration. A densely white-woolly form with long hairs on the stems and lower leaf margins was described as $P$. lodiculoides var. floccosus, but treated as a synonym by Luteyn (1999). That synonymy is provisionally accepted here, since other characteristics are the same, and the difference in pubescence seems likely due to environmental variation. A photograph of mature ring-shaped cushions of the floccose form was published by Moldenke (1976, p. 50). 
This species is also unique in the complex for the variable sex ratios of the capitula, which may be all staminate to mostly pistillate on the same plant. Capitula with exclusively pistillate flowers were not observed. Pedraza-Peñalosa et al. (2005) describe capitula with staminate flowers peripheral, but this was not observed in herbarium material.

The type of Syngonanthus steyermarkii Moldenke is the northernmost record of the species. It differs by the shorter peduncles (2-3 mm vs. $5-11 \mathrm{~mm}$ ), shorter sheaths (1.7-2.2 $\mathrm{mm}$ vs. $3-5 \mathrm{~mm})$ and capitula only about half the diameter of other specimens $(1.4-1.5 \mathrm{~mm}$ vs $2.5-3 \mathrm{~mm})$. The peduncle sheaths of this specimen are also abnormally developed, the apical lobe resembling an involucral bract in color and texture. Steyermark described the habitat as a limestone outcrop, which, if true, would be unusual for Eriocaulaceae, which almost universally occur on acidic substrates.

The three names cited in synonymy here were first cited as synonyms by Luteyn (1999) at my suggestion.

Additional specimens examined. COLOMBIA. Bogotá, D.C.: Sumapaz, Páramo de Chisacá, 3900 m, 9-11 Nov 1958, Barclay \& Juajibioy 6113 (F,MO); 22 Mar 1959, Barclay 7183 (MO); Parque Natural de Sumapaz, La Union - La Pedregal 3350-3720 m, 13-15 Jan 1997, Betancur 6935 (MO); Páramo Chisacá, 3680-3700 m, 16 Sep 1961, Cuatrecasas \& Jaramillo 25987 (F); Andabobos, 3720-3760 m, 8 Jan 1969, Cuatrecasas \& Idrobo 27054 (F); Páramo Chisacá, 3596 m, 26 Sep 1966, Soderstrom 1262 (MO); Lagunas de Chisacá, 3600 m, 15 Feb 1964, Uribe 4672 (MO). Boyacá: Nevado del Cocuy, valle de Las Lagunillas, 4000-4300 m, 12 Sep 1938, Cuatrecasas 1537 (F); Páramo del Pedrisco, km 270 Sogamoso - Pajarito, 3000 m, 27 Aug 1953, Langenheim 3589 (F,MO); Santander: Paramo de Almorzadero, 3600 m, 1 Jan 1960, Barclay 10412 (MO). ECUADOR. Loja: Muletrack Amaluza - Palanda, 3350-3450 m, 22 Sep 1976, Øllgaard \& Balslev 9717 (F). PERU. Piura: Huancabamba, El Talanco, 13 Jun 1961, Acleto 572 (USM [photo]), 3400 m, 12 Jun 1961, Friedberg 256 (USM [photo]); Huancabamba, Huaringas, 3957 m, May 1984, H. Ochoa 13 (USM [photo]).

\section{Paepalanthus pilosus (Kunth in H.B.K.) Kunth}

Paepalanthus pilosus (Kunth in H.B.K.) Kunth, Enum. Pl. 3: 518. 1841.

Eriocaulon pilosum Kunth in H.B.K., Nov. Gen. Sp. (quarto ed.) 1: 251-252. 1815 [1816].

Type: Colombia. Cundinamarca: "Crescit in frigidis montanae planitiei Bogotensis inter Suba et Suacha, alt. 1340 hex., Jul 1801, Bonpland \& Humboldt s.n. (lectotype, here designated: B [B_10_0243899] in part, as to plants mounted on left and right side of sheet. The plant mounted in the center of the sheet is $P$. dendroides (Kunth) Kunth. Syntypes: B [B-W 2371], HAL [HAL0109743], P [P01762720]). 
? Eriocaulon selaginoides Benth., Pl. Hartw. 260. 1846.

Type: Colombia. Cauca: Popayán, near Laguna de Guanacas, 12,000ft, [yr 1842],

K. T. Hartweg 1445 (holotype: K [K000640107]; isotypes: K [K000640106], B,

BM [BM000793062], E [E00319822], LE [LE00001221])

? Paepalanthus selaginoides (Benth.) Körn., Fl. Bras. 3(1): 362. 1863.

Type: Based on Eriocaulon selaginoides Benth.

Dupatya pilosa (Kunth) Kuntze, Revis. Gen. Pl. 2: 746. 1891.

Type: Based on Eriocaulon pilosum Kunth in H.B.K.

Paepalanthus kupperi Suess., Bot. Jahrb. 72: 293, t. 3, fig. 8. 1942.

Type: Costa Rica. Cartago/Limón/San José: [Cerro] Chirripó Grande, 3450 m, W.

Kupper 1315 (holotype: M [M0137218]; isotype: LL)

Paepalanthus espinosianus Moldenke, Phytologia 2: 228. 1947.

Type. Ecuador Morona-Santiago: trail between Pailas and El Pan, 3400 m, 10

Sep 1943, J.A. Steyermark 54342 (holotype: NY; isotypes: F, US [US00088348]).

Paepalanthus loxensis Moldenke, Phytologia 2: 229. 1947.

Type: Ecuador. Loja: between Tambo Cachiyacu, La Entrada, and Nudo de Saba-

nilla, 2500-3500 m, 7 Oct 1943, J. A. Steyermark 54452 ['54432' in protologue]

(holotype: NY; isotypes: F, GH [GH00028921], US [US00088367]).

Paepalanthus subsessilis Moldenke, Phytologia 2: 232.1947.

Type: Venezuela. Lara: between Buenos Aires and Páramo de las Rosas, 2285-

3290 m, 11 Feb 1944, J. Steyermark 55495 (holotype: NY; isotypes: F, US [US00088407], VEN [VEN31215]).

Paepalanthus schultesii Moldenke, Bot. Mus. Leafl. 16(4): 65. 1953. Syn. nov.

Type: Colombia. Cundinamarca: Macizo de Bogotá, Quebrada de Chapinero,

$9000 \mathrm{ft}, 24$ Sep 1941, R. E. Schultes 1024 (holotype: NY).

Paepalanthus dennisii Moldenke, Phytologia 7: 88. 1959. 'dennisi.' Type citation corrected by Moldenke, Phytologia 7: 120. 1959. Syn. nov.

Type: Venezuela Merida: Mucubaji, Sierra de Santo Domingo, 3550 m, 26 Aug

1958, R. W. G. Dennis s.n. (holotype: K [K000640179]; isotype: LL).

Paepalanthus karstenii var. minimus Moldenke, Phytologia 30: 15. 1975. Syn. nov.

Type: Colombia. Cundinamarca: Laguna de Verjón, 27 Jul 1917, Bro. Aristé Joseph A.73 (holotype: US [US0088357]; isotype: LL).

Paepalanthus karstenii var. subsessilis (Moldenke) Moldenke, Phytologia 32: 47.1975.

Type: Based on Paepalanthus subsessilis Moldenke

Type. Based on E. pilosum Kunth in H.B.K.

Misapplied names. Eriocaulon microcephalum sensu Standley (1937), non Kunth in H.B.K.; Paepalanthus dendroides sensu Madriñán and Zapata (2001), in part, non (Kunth in H.B.K.) Kunth; Paepalanthus karstenii sensu Moldenke (1952, 1975a, 1976, 1983) in large part, Espinosa (1997), Cleef (1981), Madrinán and Zapata (2001), PedrazaPeñalosa et al. (2005), Rangel-Ch. et al. (1997), (Aubert et al. 2014a,b), among others. 


\section{5a. Paepalanthus pilosus (Kunth in H.B.K.) Kunth var. pilosus}

Figs 1A-B; 2D, F-J; 3B; 11A-D; 12A-K

\section{Paepalanthus pilosus (Kunth in H.B.K.) Kunth var. pilosus}

Description. Densely branched cushion plants, the cushions reportedly reaching 30 $\mathrm{cm}$ in diameter (Molau 3223) and up to $10 \mathrm{~cm}$ tall (Berry 4366). Leaves subulate, recurved, 7-16 (-20) $\mathrm{mm}$ long $\times(0.5-)$ 0.7-1.3 (-1.5) $\mathrm{mm}$ wide at midpoint; apex cuspidate-acute to short-aristate, the sharp tip evident in adaxial view; usually appressed pilose adaxially near tip (in Peru and Ecuador), the hairs smooth to roughened, in northern part of range usually with conspicuous long coarse scattered cilia to apex (rare in Peru and Ecuador), often early glabrate, bright green, texture chartaceous to rigidulous, the abaxial surface smooth or with nerves salient. Peduncles appressedpilose when young especially at apex, often only $1.5-8 \mathrm{~mm}$ long and surpassed by the sheaths at anthesis, but frequently and variably elongating up to ten or more times this length $(20-100 \mathrm{~mm})$ in fruit; in Peru and Ecuador only rarely up to $50 \mathrm{~mm}$ at anthesis and strongly exsert (Cano 16840); the sheaths 3-15 mm long, scarious and glabrous or minutely tufted at apex, splitting apically into 2 or 3 triangular segments. Capitula 3-6 $\mathrm{mm}$ in diameter, often borne among the leaves at anthesis, frequently exsert in fruit, more rarely exsert at flowering. Involucral bracts equaling the capitulum to slightly surpassing it, the outer bracts $1.6-4.2 \mathrm{~mm}$ long, ovate to often triangular, pale gold or greenish especially along midvein, pilose on upper back to merely tufted or glabrate, the inner bracts more broadly ovate to triangular, sometimes tinged grayish-brown on shoulders; receptacle long-pilose. Trichomes of bract and sepal apices subacute to bulbous, obscurely tuberculate. Flowers ca.10-16 per capitulum, the pistillate peripheral, usually $1-2(-3)$ times as many as the staminate flowers. Pistillate flowers: Pedicels $0.35-0.5 \mathrm{~mm}$, fine or rarely wide and spongy, not thickened-rigid in fruit. Sepals elliptic to obovate or oblanceolate, apex acute to rounded, the base linear-ligulate to narrowly cuneate, $1.4-2.65 \mathrm{~mm}$ long, $0.3-1.1 \mathrm{~mm}$ wide at middle, $0.15-0.3(-0.4) \mathrm{mm}$ wide at base; usually tinged dusky brown above, rarely uniformly pale cream (Sagastegui 12242), short-tufted at apex, ciliate at upper margins, and usually pilose either side of the dorsal midvein; the basal half of the midrib hygroscopically thickened, spadiceous-brown in fruit and recurving when dry, the margins and distal half of the sepal remaining chartaceous, erect; sepals detaching from diaspore before dispersal. Petals oblanceolate-spatulate, acute to obtuse to emarginate, rarely (Wurdack 1616) broadly cuneiform; apex truncate-emarginate, apiculate; $1.5-2.35 \mathrm{~mm}$ long $\times$ 0.3-0.75 (-1.0) mm wide, ca. 2-6 times longer than wide, cream to brownish-tinged, pubescence similar to $P$. caryonauta; usually not thickening in fruit, dispersed with the fruit. Gynoecium with style base $0.5-1.05 \mathrm{~mm}$, nectaries with stalks $0.3-0.6 \mathrm{~mm}$ long, glandular portion dark red to brown, $0.3-0.4 \mathrm{~mm}$ long, penicillate with stiff whitish papillae at upper margin (northernmost Peru and northwards), or $0.4-0.5 \mathrm{~mm}$ long, clavate-infundibular with stiff whitish sometimes elongate papillae distributed along the outer surface, densest at the rim (Cajamarca: Celendín, Amazonas: Chachapoyas); 


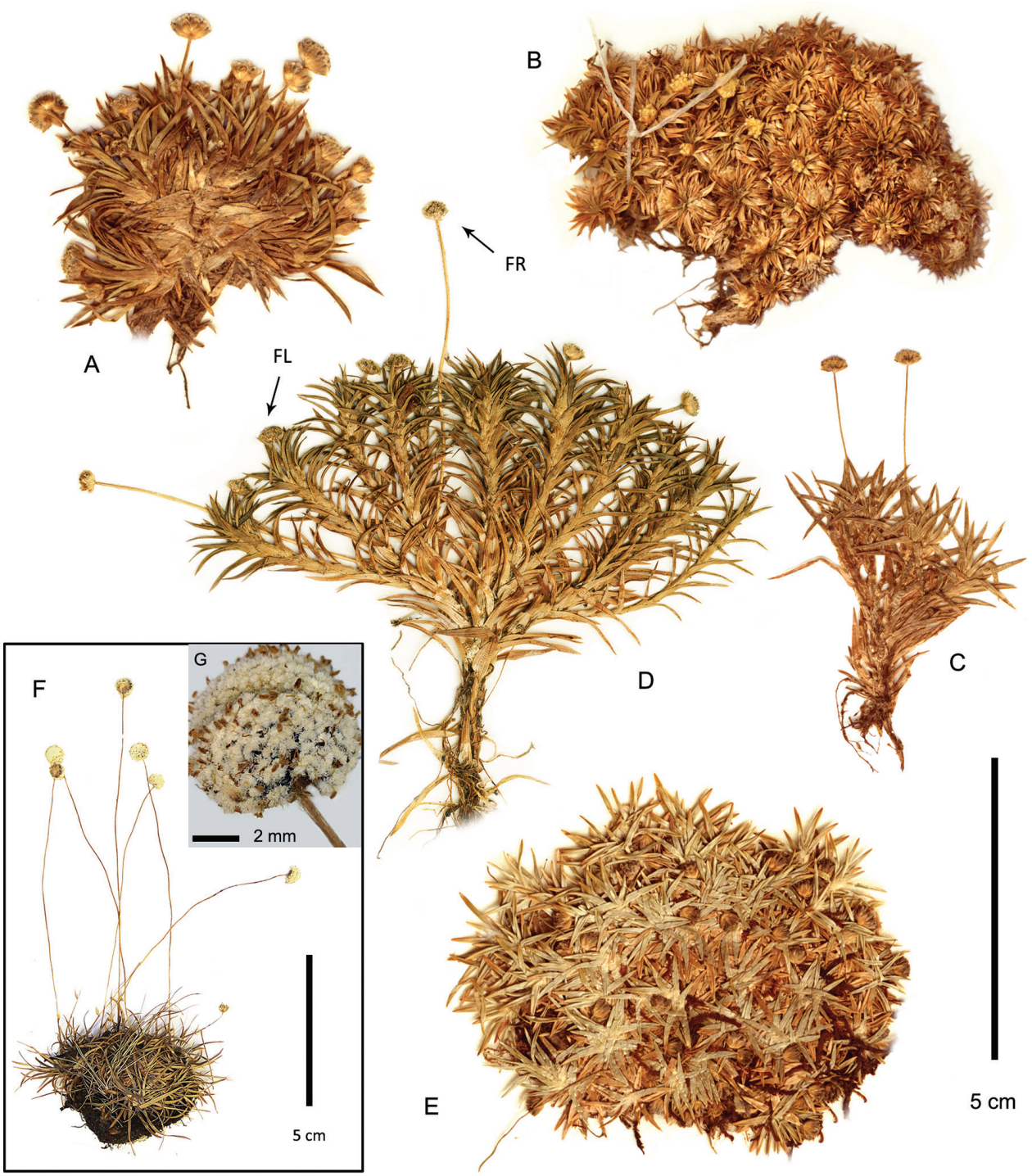

Figure II. Habits of Paepalanthus pilosus varieties and "Paepalanthus sp. A." A-D P. pilosus var. pilosus. (A Soderstrom 1346 B Sagástegui 12242 C Cano 16840 D Larsen 237.) E P. pilosus var. leoniae (León 1597) F-G "Paepalanthus sp. A" (Cuadros 3732) F Habit G Capitulum. In D arrows indicate flowering (f) and fruiting (fr) capitula.

papillae rigidulous after anthesis; styles 0.8-1.1 mm long (Barbour 3427: 1.4-1.6 mm long), dark red-brown. Seeds $0.55-0.8 \mathrm{~mm}$ long, red-brown, reticulate with abundant white erect to suberect pseudotrichomes. Staminate flowers: Pedicels 0.2-0.5 mm. Sepals $1.2-2.45 \mathrm{~mm}$, fused at base unequally, from very briefly to about $1 / 3$ sepal length, obovate to usually spatulate, acute to rounded, narrowed to base and not thickening with age. Corolla 1.2-2.5 $\mathrm{mm}$ long, the anthophore 0.5-1.5 mm long, comprising 
$30-65 \%$ the corolla length, membranous and $0.1-0.2 \mathrm{~mm}$ diameter at base, broadening to $0.2-0.3 \mathrm{~mm}$ near apex; the corolla tube including lobes $0.5-1.65 \mathrm{~mm}$ long. Filaments similar to $P$. caryonauta, usually dark red-brown between apex and the base of the corolla lobe, exsert ca.0.2-0.5 mm beyond the lobes. Nectaries reaching the sinuses of the corolla tube.

Phenology. In Central America, mostly collected January to May, and in July, coinciding with the main dry season, and possibly a shorter second dry season (veranillo), respectively (Grayum et al. 2004). In the climatically wet paramos of Colombia and Venezuela, peak flowering is June to December, generally the wet season (Rangel-Ch. 2000; Cuello et al. 2010; Vareschi 1970), though probably coinciding with short dry periods, as observed by Pedraza-Peñalosa et al. (2005). In Peru, flowering and fruiting mostly from July to September, during a pronounced dry season; in Ecuador, also during predominantly dry months from September to November (to January), fruiting through April.

Distribution. Costa Rica (Cerro Talamanca): Cartago, Limón, San José. Panama: Bocas del Toro. Colombia (Eastern Cordillera, Sierra Nevada de Santa Marta, possibly Serrania de Perijá, also rare in Western and Central Cordilleras): Antioquia, Bogotá D.C., Boyacá, Cauca, Cundinamarca, Magdalena, Norte de Santander, Santander. Venezuela (Cordillera de Merida and Ramal de Guaramacal): Apure, Lara(?), Merida, Táchira, Trujillo. Ecuador: Azuay, Loja, Morona-Santiago, Zamora-Chinchipe(?). Peru (to $7^{\circ} S$ lat.): Amazonas, Cajamarca, Lambayeque, Piura. (Fig. 6)

Habitat and ecology. Common and characteristic ground cover (rasante) or cushion species of wet páramo, rarely subpáramo, on boggy organic soils, or at pond and bog margins but not in standing water (Schmidt-Mumm and Vargas-Rios 2012); often associated with Sphagnum, usually growing amongst shrubs or bunchgrass, in Colombia frequently also with bamboo (Chusquea tessellata Munro) or Espeletia spp. (Rangel-Ch. et al. 1997; Rangel-Ch. and Ariza 2000; Vargas and Rivera 1991). It is reported by some observers as growing at the base of bunchgrass (Franco-Rosselli et al. 1986) or shrubs (Weberbauer 1945) or under rock ledges, but is also reported in full sun. In Ecuador and the western cordillera of Peru, it is occasionally reported from montane forest. Elevation (2700-) 3000-4000 (-4400) m.

Paepalanthus pilosus is a commonly cited species in phytosociological analyses of North Andean paramo, usually under the name P. karstenii (Rangel-Ch. et al. 1997). It is reported as a "characteristic and dominant species" of the alliance Paepalantho karsteni - Chusquioni tessellatae in wet páramo east of Bogotá (Rangel-Ch. and Ariza 2000). It is tolerant of disturbance and may even have a minor role in succession, being reported by several collectors as locally abundant on wet banks and roadsides, and in regenerating burnt paramo. Cleef (1981) noted that it is one of the first species after Castilleja to colonize burnt bunchgrass páramo. Cuello and Cleef (2009), in Venezuela, found it occurring abundantly in Sphagnum mats around the margins of an old lakebed undergoing succession to bunchgrass páramo, and suggested that this new azonal alliance (Sphagno-recurvi - Paepalanthion-pilosi Cuello \& Cleef) was associated with disturbance by wildlife fragmenting the Sphagnum mat. Vargas and Rivera (1991, 
quoted by Rangel-Ch. et al. 1997) found $P$. pilosus in paramo disturbed by grazing cavies and rabbits. One collector reported that the plant forms an abundant 'necromasa' with good water-retaining properties relevant to peat formation (Bernal 1647).

Conservation status. The status of this widespread variable taxon, reported as a colonizer tolerant of disturbance, is presumed to be of Least Concern (IUCN 2014).

Taxonomic history. No type material is found for E. pilosum Kunth in the herbarium P-Bonpl. in Paris (Stauffer et al. 2012). The lectotype specimen chosen from Kunth's herbarium (B) includes two individuals of $P$. pilosus, with one short-pedunculate individual of $P$. dendroides mounted between them. The middle plant is a good match for the type of $E$. dendroides Kunth, described from the same locality. Kunth's concepts of the two species were based partly on the shorter peduncles in P. pilosus, but this character varies in both species. Kunth also differentiated E. pilosum by leaves rigid, "pilose-ciliate," with a sharp apex, and involucral bracts ovate, acute, while E. dendroides was described as having leaves acuminate, membranous and glabrous, and involucral bracts obovate. These characters are adequate to distinguish the two elements on the sheet and to justify exclusion of the middle plant from the type material.

Paepalanthus pilosus has suffered confusing taxonomic treatment over time. Körnicke (1863) recognized $P$. pilosus and $P$. dendroides (both described from Bogotá) as well as $P$. selaginoides (Popayán) as distinct taxa, distinguishing $P$. selaginoides by the near obsolete peduncles, and $P$. pilosus from $P$. dendroides by the robust scattered cilia of the leaf margin. Ruhland (1903) synonymized all three under $P$. pilosus with the claim that these diagnostic characters were too variable, sometimes even within specimens, an impression perhaps fostered by the mixed sheet of $P$. dendroides and $P$. pilosus from Kunth's herbarium. At the same time, Ruhland erected an additional new species, P. karstenii, also from near Bogotá, distinguished from P. pilosus by the "leaf indument and apex," the involucral bracts broad and glabrous abaxially, and "a different form of the perianth." Inexplicably, he also described capitula as $2-3 \mathrm{~mm}$ wide in $P$. pilosus versus 6-8 $\mathrm{mm}$ wide in $P$. karstenii, which accords neither with the type of $P$. pilosus (capitula $6.5 \mathrm{~mm}$ ) nor earlier descriptions. How Ruhland thought the leaf indument, apex, or perianth in P. karstenii differed from that of $P$. pilosus is not clear from his description, leaving only the key character of bract pubescence, which also varies widely within species. In fact the broad (obovate) subglabrous bracts seen in the type of $P$. karstenii are more typical of $P$. dendroides as recognized by both Kunth and Körnicke. The identity of $P$. karstenii needs further study (see Doubtful Taxa).

Moldenke (1975b) ostensibly followed Ruhland, treating $P$. dendroides as a synonym of $P$. pilosus, and distinguishing $P$. karstenii by the "involucral bracts glabrous on the outer surface," but his use of the names in annotations (ca.1930's-1980's) doesn't correlate with bract pubescence or shape. In his pattern of annotations, Moldenke revived the appropriate distinction between $P$. dendroides and $P$. pilosus, but confused the nomenclature, mostly annotating typical $P$. pilosus as $P$. karstenii, while applying the name $P$. pilosus to $P$. dendroides and occasional long-pedunculate individuals of $P$. pilosus. This convention was followed by later authors (e.g., Cleef 1981, Madriñán and Zapata 2001). Huft's treatment (1994) was similar but treated Central American P. pi- 
losus as P. kupperi rather than P. karstenii. Hensold and Hammel (2003), in a treatment of Costa Rican species, re-established $P$. dendroides as a distinct taxon and corrected application of the name $P$. pilosus to accord with the original concept of Kunth and Körnicke, which includes both $P$. kupperi and most material determined as $P$. karstenii.

Moldenke did not specify distinguishing characters for his other species here placed in synonymy of $P$. pilosus, nor were these names widely used. Of his new infraspecific taxa, Paepalanthus karstenii f. corei was said to differ from that species by the peduncles only $1-2 \mathrm{~cm}$ in length, and $P$. karstenii var. minimus by both leaves and peduncles shorter. The type of the former is in fact $P$. dendroides, though Moldenke most commonly applied the name to $P$. pilosus and $P$. caryonauta.

Paepalanthus espinosianus and $P$. loxensis were first treated in synonymy of $P$. pilosus by León-Yánez and Hensold (1999), and P. subsessilis by Hensold (2008). Paepalanthus selaginoides was originally placed in synonymy of $P$. pilosus by Ruhland (1903) and is clearly closest to that species, but represents the only record of the species from the Central Cordillera of Colombia. Pending closer examination of the type, its placement here is provisional.

Discussion. Paepalanthus pilosus in Peru and southern Ecuador is characterized by the usually dwarf flowering peduncles with capitula subsessile at anthesis, and the outer involucral bracts greenish or with a green midvein and often longer than wide. In this area, soft hirsutulous pubescence of the upper leaf surface near the apex, similar to that found in $P$. dendroides, is common. From Costa Rica to Colombia and Venezuela, long robust scattered cilia along the distal margin are frequent and diagnostic when they occur (hence the species epithet; $c f$. Fig. 2D), but rare in our area. These cilia can often be detected even in older glabrate leaves due to the persistent enlarged basal cells. From $P$. dendroides, $P$. pilosus may also be distinguished by the relatively narrow elliptic to oblanceolate petals, and the prominent dark rigid nectaries; and from $P$. caryonauta by the usually larger capitula, the sharply acute to aristate leaf tips, and (in the typical variety) by the form of the fruiting calyx. (See Table 1.)

Habit varies from a dense compact mat pressed horizontally by collectors (as in the type of $P$. espinosianus Moldenke), to a rounded cushion with branch lengths of a few centimeters, pressed and mounted vertically (as in the type of $P$. loxensis Moldenke) The superficial difference in aspect of these two forms caused Moldenke to ally the former species with $P$. karstenii, but the latter species with $P$. glaziovii Ruhland (subsect. Dichocladus). This character almost certainly varies in response to habitat, as Heilborn (1925) noted in the vegetatively similar species Plantago rigida Kunth, which forms rounded cushions on wet sites and flat mats on drier sites. Leaves may be ascending to strongly reflexed and appressed to the ground, the latter perhaps a response to drier or sunnier conditions. An example are the collections Hernandez-Schmidt 1330 and 1432 from the same locality in Cundinamarca, the former reported on rocks in full sun, with leaves reflexed close to ground, the latter on saturated soil, with leaves erect.

Peduncle length is highly variable, as already noted by Ruhland (1903), but much of this variation may be developmental. Actively flowering capitula are usually borne on peduncles only a few millimeters long, barely emergent from the sheath, and in- 
vested by the sharp cuspidate tips of subtending foliage leaves. Dramatic peduncle elongation often occurs later in fruit, as shown by specimens bearing both subsessile flowering capitula at stem tips, and fruiting capitula lower on the stem on peduncles up to ten times as long (e.g., Larsen 237, Fig. 11D). The delayed timing of peduncle elongation may afford wind and frost protection during anthesis, while later enhancing fruit dispersal. Peduncle elongation doesn't always accompany fruiting or may be minimal, but even in specimens with many subsessile fruiting capitula still embedded in the leaf mat, occasional remains of much longer peduncles can be found (e.g. Barbour 3427, Sagastegui 12242). Notably, the only specimen from Peru and Ecuador with peduncles already elongate $(2-5 \mathrm{~cm})$ at anthesis was also the only specimen reportedly collected from "montane forest," where it was said to be rare (Cano 16840). This plant may represent a taxonomically distinct variant, but for now is treated as an environmental form. In Colombian populations of the Eastern Cordillera, early peduncle elongation may be more common.

Other characters showing wide variation in Peru and Ecuador are involucral bract length, capitulum size, and flower and seed size. For example, the type of $P$. loxensis (Loja) contrasts sharply with that of $P$. espinosianus (Azuay) by its much smaller involucral bracts, capitula, flowers, and seeds. Indeed, in most plants from Azuay, in the Cerro Fierro-Urcu (Loja), and in some localities in Peru (Jaén, Bagua, Celendín), outer involucral bracts are ca.2.6-4.0 $\mathrm{mm}$, with the tips often surpassing the large capitula 4-6 $\mathrm{mm}$ in diameter ( $c f$. Fig. $2 \mathrm{H}$ ). In contrast, most specimens from southern Loja, the western Cordillera of Peru, and southern Amazonas, Peru, have involucral bracts about 1.6-2.6 $\mathrm{mm}$ long and capitula $3-4 \mathrm{~mm}$ in diameter (Fig. 2I-J). The length of the pistillate flower sepals was measured in 18 specimens of Peru and Ecuador and was imperfectly correlated with capitulum size. Small flowers (sepals 1.4-1.8 $\mathrm{mm}$ ) were found in the small-capitate plants from southern Loja and northwestern Peru, and a few large-capitate plants of Azuay; all other specimens were large-flowered (sepals ca. 1.8-2.4 mm long). Seed size showed the strongest geographic correlation, with the smallest seeds observed in the small-flowered specimens from southern Loja and the western cordillera of Peru $(0.53-0.63 \mathrm{~mm}, 5$ samples), while elsewhere seeds were larger (0.67-0.8 mm, 8 samples). Among the large-flowered collections, those of Amazonas, Peru, south of the mouth of the Rio Utcubamba (ca. $6^{\circ} \mathrm{S}$ latitude) are distinguished by the unusually broad female petals ( $1 / \mathrm{w}$ ratio $1.8-2.9$ vs. 3.5-7.0 elsewhere), broadly rounded to even truncate-emarginate at apex (Fig. 12I), and by an ambiguous pattern of sepal thickening, both characters suggesting intermediacy with P. pilosus var. leoniae, of San Martín. Also shared with that variety are the funnelform nectaries (Fig. 12I) with unusually large, spreading papillae (also found in Sagastegui 12242, Celendín), in comparison to the commonly penicillate nectaries with small papillae found elsewhere.

Paepalanthus pilosus in Colombia requires further careful study. In the Eastern Cordillera, particularly in disturbed paramo near Bogotá, there are more pronounced morphological extremes in the species than in other parts of its distribution. Here, leaf lengths range up to $3 \mathrm{~cm}$, capitula from $3.5-8 \mathrm{~mm}$ in diameter, peduncles are occa- 


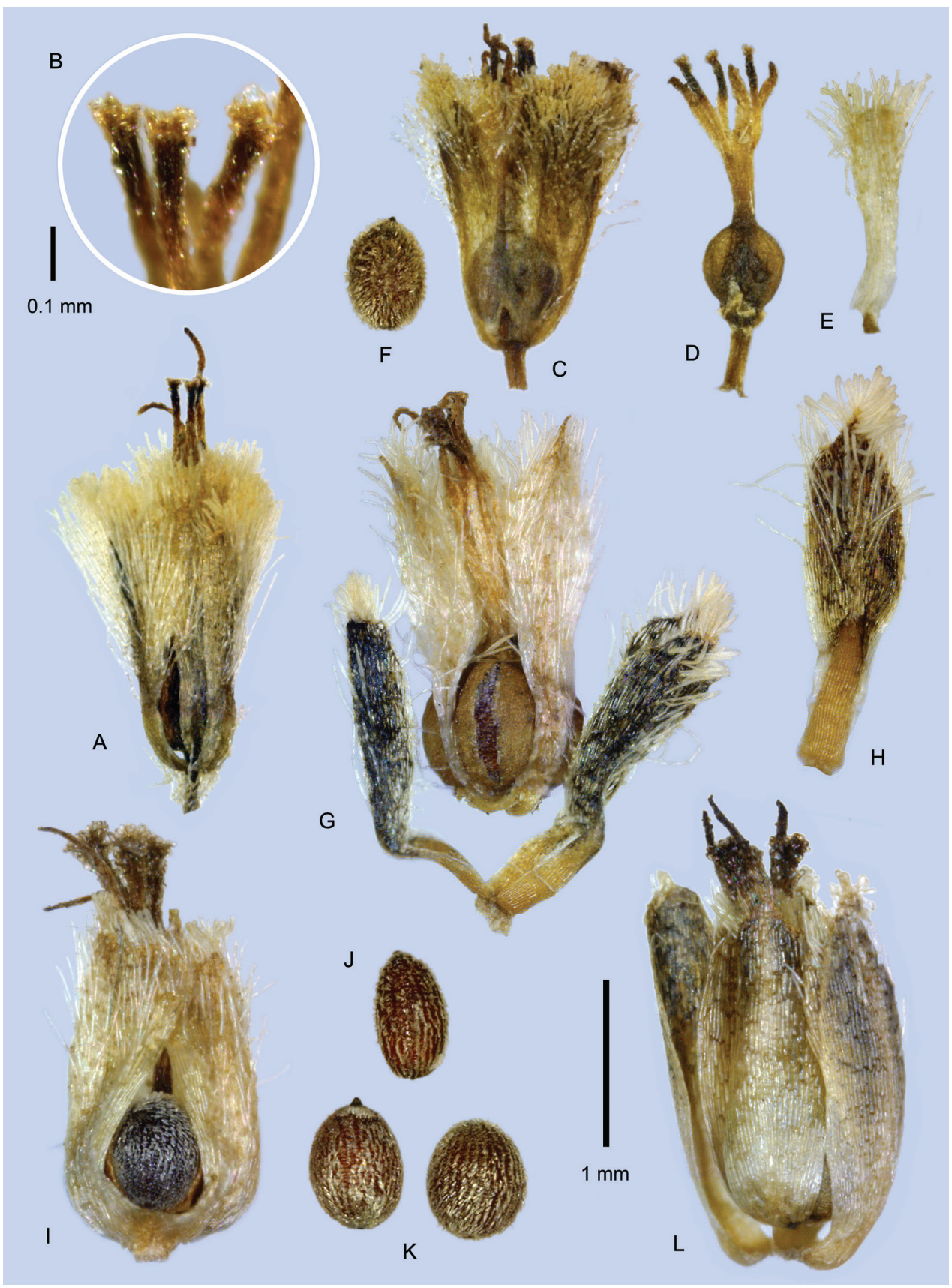

Figure I2. Pistillate flowers and fruits of P. pilosus varieties. A-K P. pilosus var. pilosus (A-B Jorgensen 2366 C-F Cano 16840 G Cuatrecasas 25574 H MacDougal 4463 I Wurdack 1616 J Øllgaard 9557 K Boeke 2133) A-B Flower in anthesis with detail of gynoecial nectaries $\mathbf{C}$ Flower in anthesis D Gynoecium E Petal F Seed G Diaspore with detached calyx H Sepal (fr) I Diaspore releasing seed J-K Seeds after wetting $\mathbf{L}$ P. pilosus var. leoniae. Mature diaspore, sepals and petals intact. (León 1597). 
sionally strongly exsert at flowering, and involucral bract color and form are variable, ranging from nearly obovate-rounded to narrowly triangular, and pale gold to dark pigmented on the shoulders. Madriñán and Zapata (2001) indicate two sympatric elements for the Páramo Chingaza, one with ciliate leaves and peduncles exceeding the leaves in length (" $P$. dendroides"), and one with leaves nearly glabrous and peduncles shorter ("P. karstenii"). However type material of both P. pilosus and P. karstenii have prominent scattered cilia of the leaf margins, and both have variable peduncle lengths, which may be quite long in fruit. Judging from the photographs, both elements from Páramo Chingaza fit within my working concept of $P$. pilosus, but the presence of two reproductively isolated crypto-taxa in this area cannot be ruled out. Some differences especially in leaf size, orientation and pubescence may be due to microhabitat, but polymorphism does seem more exaggerated in collections from the vicinity of Bogotá than from elsewhere, and collectors have often recognized two elements at one locality (e.g., Barclay 4031, 4057, Paramo de Guasca; Dwyer 8186, 8189, Paramo Cruz Verde; Rangel 4045, 4048, Boyacá, Duitama). For simplicity I have treated as $P$. pilosus all forms with subulate, sharply cuspidate leaves and the flower and fruit structure described above, and consider robust spreading cilia of the distal leaf margin also diagnostic when present, as it is in P. pilosus of Venezuela and Central America. This may however obscure a more complicated taxonomic picture.

Hybridization may be a factor contributing to the chaotic variation in P. pilosus in the vicinity of Bogotá. Some material, such as the type of $P$. karstenii (see Doubtful Taxa) looks intermediate with $P$. dendroides, as to elongate peduncles and rounded involucral bracts. Typical $P$. dendroides was originally described from Bogotá, but has not been collected in the vicinity since 1917, while it is still widespread elsewhere. In addition, probable hybrids between $P$. pilosus and $P$. caryonauta have been collected at the margins of the range of $P$. pilosus, at Paramo Frontino (Antioquia), and on the eastern slope of Paramo Sumapaz, south of Bogotá (see P. caryonauta discussion).

A final complication in the taxonomy of Colombian P. pilosus is the presence in the Serranía del Perijá and vicinity of a closely related but more robust taxon, which may intergrade with it, discussed below under Paepalanthus sp. A.

Selected specimens examined (of 122 total). COSTA RICA. Cartago: Cerro Asunción, 3350 m, 19 Mar 1978, Wilbur 26123 (F). Limón: Parque Nac. Chirripó, Valle Las Morrenas, 9²9'24"N, 83²9'24"W, 3500 m, E. Alfaro 417 (MO). San José: Canton de Dota, Cerro Vueltas, 9³7'40"N, 8351'10"W, 3150 m, 28 Mar 1994, Cascante et al. 212 (F,MO); Cerro Chirripó, 9 $27^{\prime} 36^{\prime \prime N}, 83^{\circ} 29^{\prime} 24^{\prime \prime W}, 3400-3739$ m, 27 Jul 1996, Gamboa R. et al. 490 (MO). PANAMA. Bocas del Toro: Cerro Fábrega, $9^{\circ} 07^{\prime} \mathrm{N}, 82^{\circ} 52^{\prime} 40 " \mathrm{~W}, 3100-3300 \mathrm{~m}, 6-8$ Mar 1984, Davidse et al. 25303 (F,MO). COLOMBIA. Antioquia: Mpio. Urrao, Paramo Frontino, near Llano Grande, 3450 m, 27 Oct 1976, Boeke \& McElroy 265 (NY [01347937] p.p., mixed with P. caryonauta $\times$ P. pilosus at top center), Ibidem, 3320-3450 m, 2 Mar 1989, MacDougal \& Roldán 4463 (MO). Bogotá, DC: Entre Alto de las Cruces-La Viga y Diego Largo, 3380-3320 m, 19 Jun 1939, Cuatrecasas 5553 (F); Páramo de Chisacá, 3660- 
3720 m, 11 Sep 1961, Cuatrecasas \& Jaramillo 25882 (F); Páramo de Cruz Verde, 3300-3500 m, 20 Sep 1917, Pennell 2074 (F,MO); Paramo de Sumapaz, 3750 m, 8 Aug 2003, S. Rios et al. 16 (UDBC [UDBC15910]). Cerro Monserrate, 26 Apr 1951, Romero-Castaneda 2492 (F); Páramo de Chisacá, 3596 m, 15 Oct 1966, Soderstrom 1346 (MO); Usme, Predio El Refugio EAAB, alt. 3726 m, 2 Aug 2011, Trujillo 600 (UDBC [UDBC30513]). Boyacá: Nevado del Cocuy, valle de Las Lagunillas 4000-4300 m, 12 Sep 1938, Cuatrecasas 1501 (F); Paramo de la Rusia, Duitama Charalá, 3624 m, 20 Aug 1953, Langenheim 3508 (MICH); Duitama, Paramo de Belen, 0601'35"N, 72 57'08"W, 3900 m, 30 Sep 1986, Rangel et al. 4045 (MO). Cundinamarca: Paramo de Guasca, 3000-3400 m, 13 Jun 1957, Barclay 4031 (MO); Represa de Neusa, 3500 m, 22 Jun 1957, Barclay 4150 (MO); Boqueron de Chipaque, 3350 m, 12 Jul 1957, Barclay 4489 (MO); Páramo de Choachi, 3400 m, 18 Jun 1959, Barclay 7757 (MO); Mpio. de Fómeque, Sector La Playa (Parque Nac. Natural Chingaza), 3180 m, 31 Aug 1991, Bernal et al. 1647 (COL [COL000066835]); La Calera, Paramo de Palacio, 3420-3500 m, 8 Dec 1959, Cuatrecasas et al. 25574 (F); Mpio. Subachoque, Paramo El Tablazo, 3400 m, 6 Oct 2003, M. Hernandez Schmidt et al. 1330 (COL [COL000034189]), 12 Dec 2003, M. Hernandez Schmidt 1432 (COL [COL000034188]); Sopó, 2700 m, 14 Feb 1951, Schultes 11590 (MO). Magdalena: Sierra Nevada de Santa Marta, Laguna Chubdula, $10^{\circ} 55^{\prime} \mathrm{N}, 73^{\circ} 53^{\prime} \mathrm{W}, 3480$ m, 29 Jul 1972, Kirkbride \& Forero 1784 (F); Slopes of Cuchilla Chebachucua, valley of Rio Duriameina, $10^{\circ} 38^{\prime} \mathrm{N}, 73^{\circ} 38^{\prime} \mathrm{W}, 3500 \mathrm{~m}, 31$ May 1977, S. White \& Alverson 642 (MO). Norte de Santander: Cucutilla, Páramo El Romeral, 3200-3800 m, 25 Feb 2002, Ortiz R. et al. 978 (COL [COL000066965]); Santander: Paramo del Almorzadero, 3600 m, 1 Jan 1960, Barclay 10394 (MO). VENEZUELA. Apure: Distr. Paéz, paramo de Tamá, 3100 m, 26 Jun 1973, Ruiz-Teran \& López-Figueiras 8555 (MICH). Lara/Trujillo: Parque Nacional Dinira, Paramo de Jabón, vista al Tocuyo, $09^{\circ} 33^{\prime} 55^{\prime \prime N}, 70^{\circ} 06^{\prime} 18^{\prime \prime W}, 3000$ m, 13 Aug 1999, Riina et al. 522 (F). Merida: Distr. Rangel, Sierra de Santo Domingo, paramo de Mucubaji, 3560-3600 m, 19 Nov 1959, Barclay \& Juajibioy 9565 (MO); Distr. Justo Briceño, Alto del Totumo, hoya del Río Chirurí, a 19.5 km de El Aguila, 3900-4000 m, 11 Oct 1983, Berry 4229 (F); Distr. Campo Elias, San Jose de Acequias - Mucutuy, 3120 m, 22 Aug 1984, Berry 4366 (F,MO); Distr. Rangel, Paramo de Mucuchies, 3750 m, Sept 1952, Humbert 26300 (F); Distr. Miranda, Timotes - Paramito, 2285-3500 m, 24 Mar 1944, Steyermark 55727 (F); Distr. Libertador, La Aguada, 3475 m, 17 Dec 1969, Steyermark \& Koyama 102359 (F,MO). Táchira: Paramo de Tamá, Pata de Judio, 3100-3500 m, 19 Oct 1978, Luteyn et al. 5927 (MO). Trujillo: Parque Nac. Guaramacal, 2800-3100 m, 15 Jun 2001, Dorr et al. 9005 (F). ECUADOR. Azuay: Paramo de Matanga, 0313'42"S, 7857'14"W, 3340 m, 18 Jul 2006, Aedo et al. 13036 (MO); Gualaceo - Limón, side

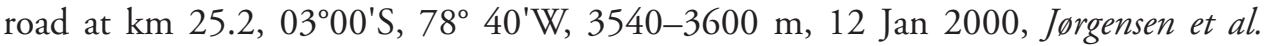
1851 (F,MO); Sigsig - Gualaquiza, km 28, 03 11'48"S, 7847'09"W, 3280-3330 m, 14 Nov 2000, Jørgensen et al. 2366 (F,MO). Azuay/Morona-Santiago: Muletrack Sevilla de Oro-Mendez (Paramo de Castillo), $2^{\circ} 48^{\prime} \mathrm{S}, 78^{\circ} 36^{\prime} \mathrm{W}, 3250-3500 \mathrm{~m}$, 16 Sep 1976, Øllgaard \& Balslev 9557 (F). Loja: Tambo de Savanilla, 18 Oct 1876, 
André K-1438 (F); Fierro Urco, Saraguro-Loja, 0343'10"S, 79 19'18"W, 3840 m, 6 Dec 1994, Jorgensen et al. 1241 (MO); Yangana - Valladolid, 2800-2900 m, 5 Sep 1985, Larsen \& Dall 237 (MO), Ibid., 3150 m, 14 Nov 1997, Lewis \& Klitgaard 3726 (MO). PERU. Amazonas: Prov. Bagua, Cordillera Colán 3290 m, 9 Sep 1978, Barbour 3427 (F,MO); Prov. Chachapoyas, Leimebamba-Chilchos trail, 4 Jul 1977, Boeke 2133 (MO,USM n.v.); Prov. Luya, Distrito Camporedondo, Tullanya, 060.'29"S, 78¹8'44"W, 3320 m, 8 Dec 1996, R. Vásquez-M. \& Rojas 21996 (MO); Prov. Chachapoyas, $3000 \mathrm{~m}$, Weberbauer 4416 (F frag ex G); Molinopampa - Diosan pass, 3100-3300 m, 5 Aug 1962, Wurdack 1616 (F). Cajamarca: Prov. Jaén, Sallique, Localidad El Páramo, 0540'51"S, 79¹9'00"W, 3400 m, 22 Jul 1998, Campos et al. 5334 (F,MO); Prov. Celendín, Jalca de Kumulca, 3300 m, 18 Aug 1984, Sagástegui et al. 12242 (F,MO). Lambayeque: Ferreñafe, Cañaris, 3253 m, 22 Apr 2010, Chocce et al. 5688 (USM [photo]); Piura: Huancabamba, Carmen de la Frontera, Nueva York, 3160 m, 28 Jul 2006, Cano et al. 16840 (F,USM [photo]).

\section{5b. Paepalanthus pilosus var. leoniae Hensold, var. nov. urn:Isid:ipni.org:names:77155459-1}

Figs 11E, 12L

Diagnosis. Differs from the typical variety by the capitula $2-3 \mathrm{~mm}$ in diameter, flowers 5-10 per capitulum, the pistillate flowers with sepals elliptic, uniformly thickened in fruit and dispersed with the fruit; petals of pistillate flowers oblong to oblongspatulate with broadly rounded to truncate apex.

Type. PERU. San Martín: Prov. Mariscal Caceres, NW sector Rio Abiseo National Park, grassland in Paredones, [07 $40^{\prime} 16.73^{\prime \prime S}, 77^{\circ} 29^{\prime} 1.78^{\prime \prime W}$ ], 3600 m, 16 March 1988, B. León \& K. Young 1597 (Holotype: MO!).

Description. Leaves $5.5-12 \mathrm{~mm}$ long $\times 0.6-1.4 \mathrm{~mm}$ wide at midpoint, sharply cuspidate, finely appressed-ciliate near apex when young, early glabrate. Peduncles 3-6.5 mm long, fruiting peduncles the same length in specimens observed, the sheaths 5-7 $\mathrm{mm}$. Capitula 2-3 $\mathrm{mm}$ in diameter, the involucres obconic or cupulate in flower and fruit, not opening broadly, the bracts similar to typical variety. Flowers 5-10 per capitulum, the staminate equal in number to pistillate or in fewer-flowered capitula the proportion of staminate flowers may be reduced. Pistillate flowers: Pedicels 0.25$0.35 \mathrm{~mm}$. Sepals elliptic, obtuse to rounded, $1.35-2.4 \mathrm{~mm}$ long $\times 0.65-0.8 \mathrm{~mm}$ wide at middle, $0.25-0.35 \mathrm{~mm}$ wide at base, pale brownish, tinged dusky-brown on shoulders, becoming uniformly thickened and cymbiform at maturity, enclosing the fruit and dispersed with it. Petals oblong to oblong-spatulate, with apex broadly rounded to truncate, retuse or apiculate, $1.5-2.0 \mathrm{~mm}$ long $\times 0.65-0.85 \mathrm{~mm}$ wide, $2.2-2.5$ times longer than wide, pilose as in the typical variety or with trichomes restricted to subapical tufts, uniformly thickening in fruit, as the sepals. Gynoecium with style base 0.5-0.65 mm long, nectaries $0.65-1.0 \mathrm{~mm}$ long, papillae at upper margin colorless, stiff, globose (Leon 1597) to linear (Young 4368); style branches $0.75-1.7 \mathrm{~mm}$. Seeds 
not seen but mature ovary locules $0.65 \mathrm{~mm}$ (Young 4368), $0.75 \mathrm{~mm}$ (Leon 1597). Staminate flowers: Pedicels $0.25-0.35 \mathrm{~mm}$. Sepals $1.35-2.1 \mathrm{~mm}$ long, fused 35-55 $\%$ of their length. Corolla $1.55-2.05 \mathrm{~mm}$ long, with the anthophore $0.85-1.15 \mathrm{~mm}$ long, comprising $45-75 \%$ the length of the whole corolla, ca. $0.1-0.25 \mathrm{~mm}$ in diameter at base, the tube and lobes $0.4-1.05 \mathrm{~mm}$ long. Filaments brownish toward apex; nectaries reaching corolla sinuses.

Etymology. Named in honor of Dr. Blanca León, of the Universidad Nacional Mayor de San Marcos and the University of Texas, a generous and accomplished botanist whose many contributions include ecological and taxonomic study of Rio Abiseo National Park.

Phenology. Collected in March and July. A mild dry season occurs June to August (Young and Leon 1988).

Distribution. Endemic to Peru, San Martín, Prov. Mariscal Caceres, Rio Abiseo National Park. (Fig. 6)

Habitat. From high-elevation grasslands, at 3450-3800 m. Young and León (1988) compare the habitat to the wet páramos of southern Ecuador, and note that the U-shaped valleys at high elevations where this variety was collected were glaciated as recently as 12,000 years ago.

Conservation status. Endangered, Criteria B1ab(iii) (IUCN 2014). This variety is known from only two sites $10 \mathrm{~km}$ apart in the protected area of Rio Abiseo National Park In recent years, cattle-grazing, which may have been a threat, has ceased (B. León, pers. comm.) However, the very small distribution, and the fact that this variety represents the southernmost occurrence of a wetland páramo species suggests vulnerability to climate fluctuations.

Discussion. This variety is found at the southernmost and highest elevation station for the species in Peru. It occurs above $3400 \mathrm{~m}$ at the very south end of the Amotape-Huancabamba floristic zone as characterized by Weigend (2004), in the drainage of the Rio Huallaga. This compares to the typical variety collected at up to $3400 \mathrm{~m}$, in the drainage of the Rio Marañón.

The uniformly thickened fruiting perianth of this variety is similar to that of $P$. caryonauta, complicating the otherwise tidy distinction between the two species. However the size and shape of the leaves, the dwarf peduncles, the pale greenish involucres, and the large rigid nectary papillae, all suggest $P$. pilosus, and the type specimen in particular looks nearly identical to populations of typical $P$. pilosus from adjacent southern Amazonas. In fact, these populations are partly intermediate in floral morphology between the two varieties, as discussed under the typical variety. Given the variation in P. pilosus in Peru and the contiguity of distribution, it seems best for now to treat this taxon as a variety of that species.

The specimen Young \& León 4368, collected ca. $10 \mathrm{~km}$ from the other two, is marked by the very small size $(5.5-7 \mathrm{~mm})$ of the dark green leaves. The flowers and seeds are also smaller. The habitats of the two localities differed, with the type locality a typical patchy wet páramo among outcrops, while the small-leaved plant was in a broad boggy area bordered by small trees, where cattle once pastured (B. León, pers. comm.) 
Additional specimens examined. Perú. San Martín: Prov. Mariscal Caceres. Puerta del Monte, northwest corner of Rio Abiseo National Park; high elevation grassland on bottom of u-shaped valley; [7³9'30.20"S; 77²8'13.67"W], $3450 \mathrm{~m}, 10$ Jul 1987, K. Young \& B. León 4368 (F); Pastizales de Empedrada, entre manojos de Calamagrostis, [0740'17"S, 77²9'2" W], 3750-3785 m, 27 Jul 2000, B. León \& K. Young 4579 (USM [photo!]).

\section{Paepalanthus Species A}

Figs 6, 11F-G

Misapplied (?) name. Paepalanthus macarenensis sensu Moldenke (1983) in part, and Rivera-Díaz (2010), probably non Moldenke (1952).

This robust taxon has a clumping habit structurally similar to $P$. pilosus but lacks the dense pulviniform aspect. Its other similarities include acute to aristate leaves, scarious splitting peduncle sheath tips, pale gold lanceolate involucral bracts, and a nearly identical flower and fruit morphology. It differs by the following characters:

Leaves longer, narrowly linear-lanceolate, 3-4 cm long, the peduncles 10-20 cm long at anthesis, and the capitula $6-7.5 \mathrm{~mm}$ wide, much more floriferous ( $>40$ flowers) than P. pilosus and sometimes globose at maturity, with alternating whorls of staminate and pistillate flowers. In addition, the capitula are "indeterminate," with floral primordia found at the center of capitulum at the time of anthesis of the outer whorls. This contrasts with $P$. pilosus, in which pistillate flowers are limited to the outer whorl, staminate to the inner, and no floral primordia are found at the start of anthesis.

The most robust individuals are found in the northern part of Serrania del Perija (ca. $10^{\circ} 15^{\prime}-10^{\circ} 20^{\prime} \mathrm{N}$ ), but similar smaller plants are also found at the north end of the main Cordillera Oriental, about $300 \mathrm{~km}$ to the south. These have leaf, peduncle and sheath lengths approaching those of the Perijá plants, and in spite of their small capitula, the flowers are more numerous than in typical P. pilosus (up to 40 per capitulum), and pistillate and staminate whorls alternate in the capitulum. It isn't clear whether to treat these plants as small individuals of Paepalanthus sp. A, or intermediates with $P$. pilosus. Smaller individuals are also found at Sa. de Perijá (Cuatrecasas 25027, 25143, US), but were only observed from scans.

The plants of Perijá had been distributed in part as $P$. macarenensis, a species otherwise only known from ca. $800 \mathrm{~m}$ in the Sierra de la Macarena (Meta). I have seen an image of the $P$. macarenensis type, and do not believe it is the same species or closely related, but pending closer examination treat the Perijá plants only provisionally here.

Specimens examined. COLOMBIA. Cesar: [Serranía de Perijá], Paramo de Sabana Rubia, 3250 m, 22 Jul 1987, H. Cuadros 3732 (MO), east of Manaure, Sabana Rubia, paramo, 3000-3100 m, 6-8 Nov 1959, J. Cuatrecasas \& R. Romero-Castaneda 25025 (COL [COL000223802], US n.v.), La Paz, Corr. San Jose de Oriente, Vda. Altos del Riecito - Altos de Perijá, Fca. Los Sauces, 10¹4'48.75"N 7257'44.5"W, 3096 m, 27 Feb 2006, J. O. Rangel 13692 (COL [COL000254069]) 
Smaller individuals. COLOMBIA. Norte de Santander: de La Laguna a Nariz de Judío (Mutiscua), 19 Jun 1946, M. de Garganta 1209 (F); Santander: Paramo de Las Vegas, 3700-3800 m, 20-21 Dec 1926, E. P. Killip \& A. C. Smith 15626 (F); Paramo de Santurban, between Tona and Mutiscua, 3800-4300 m, 18 Feb 1927, E. P. Killip \& A. C. Smith 19557 (F).

\section{Doubtful taxon}

\section{Paepalanthus karstenii Ruhl.}

Paepalanthus karstenii Ruhl., Pflanzenr. IV. 30: 155. 1903.

Type: Colombia. Cundinamarca: Páramo de Chipaque, [yrs 1848-1856], $H$.

Karsten s.n. (holotype: W, destroyed [F neg. no. 29991]; lectotype, here designated: B [B_10_0243950]; isotype: LL [LL00374731]).

Dupatya karstenii (Ruhl.) Gleason, Bull. Torrey Bot. Club 53: 195. 1925.

Type. Based on Paepalanthus karstenii Ruhl.

These unusual specimens with large capitula, broadly rounded bracts, coarsely ciliate leaves, and irregular leaf lengths appear intermediate between $P$. pilosus and $P$. dendroides as to bract characters and habit, and were collected at an elevation where distributions would potentially overlap. A topotype (Paramo de Chipaque, $3000 \mathrm{~m}$, Dec 1855, J. J. Triana 1022-5, COL [COL 000302503]), det. P. dendroides by Killip, has similar features but even wider variability. This may be a variant of $P$. pilosus or a hybrid taxon and needs closer study.

\section{Invalid names}

Eriocaulon caulescens Willd. mscr., non Poir. nec Hook.f. \& Thomson ex Thwaites. Based on: Humboldt \& Bonpland s.n. (B-Willd. 2366 [BW02366000]), annotated as E. caulescens on sheet and folder. Presumed syntype of E. dendroides Kunth in H.B.K.

= Paepalanthus dendroides (Kunth) Kunth

Eriocaulon parvum Ruíz \& Pav. nom. nud., non Körn. Cited by H. Ruíz (1940, p. 230). Annotated sheets: PERU. [Huánuco:] Saxiapata, Ruiz \& Pavón s.n. (MA [MA810392, MA810393, MA810394], probable duplicate, MO, acc. no.1612102). Collected "in the montana of Pillao and Chacahuasi," Aug-Sept 1787, according to Ruíz (1940).

= Paepalanthus dendroides (Kunth) Kunth 


\section{Excluded taxon}

Paepalanthus pilosus var. microcephalus Moldenke, Phytologia 55(6): 372.1984.

= Paepalanthus lamarckii Kunth, in P. ser Leptocephali (Ruhl.) Giul.

Synonymy according to Huft (1994).

\section{Acknowledgments}

I thank the Field Museum Department of Botany and Keller Science Action Center for research space and use of equipment. I am especially grateful to Robin Foster for photos of specimens at USM, and to Mark Johnston (F) for technical help with distribution maps. Philippe Coler, Station Alpine Joseph Fourier, kindly granted permission to use Serge Aubert's photos of P. pilosus in the field. Thanks also to Blanca León and Asunción Cano (USM), Antoine Cleef, Juliana Lovo (SP), Mary Merello (MO), Rafaela Forzza (RB), and Andrew Clark (US) for photos, comments, discussion, or all three. Curators of the following herbaria provided access to specimens: F, MO, MICH. Careful reviews by Livia Echternacht, Ana Giulietti, and Thomas Stützel greatly improved the manuscript. I am indebted to Amy Bateman Hensold for moral and tactical support.

\section{References}

Andrade MJG, Giulietti AM, Rapini A, Queiroz LP, Conceição AS, Machado de Almeida PR, van den Berg C (2010) Comprehensive phylogenetic analysis of Eriocaulaceae: Evidence from nuclear (ITS) and plastid ( $p s b \mathrm{~A}-\operatorname{trn} \mathrm{H}$ and $t r n \mathrm{~L}-\mathrm{F}) \mathrm{DNA}$ sequences. Taxon 59: 379-388. http://www.ingentaconnect.com/content/iapt/tax/2010/00000059/00000002/ art00004\#expand/collapse

Aubert S, Boucher F, Lavergne S, Renaud J, Choler P (2014a) 1914-2014: A revised worldwide catalogue of cushion plants 100 years after Hauri and Schröter. Alpine Botany 124(1): 59-70. doi: 10.1007/s00035-014-0127-x

Aubert S, Boucher F, Lavergne S, Renaud J, Choler P (2014b) A worldwide catalogue of cushion plants 100 years after Hauri and Schröter. [Companion resource to above article.] http://www.cushionplants.eu [accessed 30 Jan 2016]

Balslev H (2001) Vascular plants on Volcán Chiles and Páramo del Angel, Ecuador - a preliminary list. In: Ramsay PM (Ed.) The Ecology of Volcán Chiles: High-altitude Ecosystems on the Ecuador-Colombia Border. Pebble \& Shell, Plymouth, 1-25.

Boyle B (2001) Vegetation of two sites in the northern Cordillera de Vilcabamba, Peru. In: Alonso LE, Alonso A, Schulenberg TS, Dallmeier F (Eds) Biological and social assessments of the Cordillera de Vilcabamba, Peru. RAP Working Papers 12 and SI/MAB Series 6, Conservation International, Washington, D.C., 69-79. https://ibrary.conservation.org/ Published\%20Documents/2009/RAP_Working\%20Papers_12.pdf 
Brako L, Hensold N (1993) Eriocaulaceae. In: Brako L, Zarucchi J (Eds) Catalogue of the Flowering Plants and Gymnosperms of Peru. Monographs in Systematic Botany from the Missouri Botanical Garden 45: 425-426.

Cano A, Young KR, León B, Foster RB (1995) Composition and diversity of flowering plants in the upper montane forest of Manu National Park, southern Peru. In: Churchill SP, Balslev H, Forero E, Luteyn JL (Eds) Biodiversity and Conservation of Neotropical Montane Forests. New York Botanical Garden, Bronx, NY, 271-280.

Cleef AM (1981) The vegetation of the páramos of the Colombian Cordillera Oriental. Dissertationes Botanicae 61: 1-320.

Coan AI, Scatena VL, Giulietti AM (2002) Anatomia de algumas espécies aquáticas de Eriocaulaceae brasileiras. Acta Botanica Brasilica 16(4): 371-384. doi: 10.1590/S010233062002000400001

Coombes L, Ramsay PM (2001) Vegetation of a cushion mire at 3600 m on Volcán Chiles, Ecuador. In: Ramsay PM (Ed.) The Ecology of Volcán Chiles: High-altitude Ecosystems on the Ecuador-Colombia border. Pebble \& Shell, Plymouth, UK, 47-54.

Cuello NL, Cleef AM (2009) The páramo vegetation of Ramal de Guaramacal, Trujillo State, Venezuela. 2. Azonal vegetation. Phytocoenologia 39(4): 389-409. doi: 10.1127/0340269X/2009/0039-0389

Cuello NL, Cleef AM, Aymard-C GA (2010) Phytogeography of the vascular páramo flora of Ramal de Guaramacal (Andes, Venezuela) and its ties to other páramo floras. Anales del Jardín Botánico de Madrid 67(2): 177-193. doi: 10.3989/ajbm.2253

Espinosa R (1997) Estudios Botanicos en el Sur del Ecuador, Tomos I y II. (2nd ed.) Herbario LOJA, Loja, Ecuador / Univ de Aarhus, Denmark.

Foster RC (1958) A catalogue of the ferns and flowering plants of Bolivia. Contributions from the Gray Herbarium of Harvard University 184: 1-223.

Franco-Rosselli MP, Rangel-Ch. JO, Lozano-Contreras G (1986) Estudios ecológicos en la cordillera Oriental II: Las comunidades vegetales de los alrededores de la laguna de Chingaza. Caldasia 15(71-75): 219-248. http://www.revistas.unal.edu.co/index.php/cal/article/view/35042

Giulietti AM (2015) Eriocaulaceae. In: Bernal R, Gradstein SR, Celis M (Eds) Catálogo de plantas y líquenes de Colombia. Instituto de Ciencias Naturales, Universidad Nacional de Colombia, Bogotá. http://catalogoplantascolombia.unal.edu.co [accessed 30 Jan 2016]

Giulietti AM, Hensold N, Parra LR, Andrade MJG, van den Berg C, Harley RM (2012) The synonymization of Philodice with Syngonanthus (Eriocaulaceae). Phytotaxa 60: 50-56. doi: 10.11646/phytotaxa.60.1.7

Grayum MH, Hammel BE, Zamora N (2004) El ambiente físico / The physical environment. In: Hammel BE, Grayum MH, Herrera C, Zamora N (Eds) Manual de Plantas de Costa Rica Vol. I. Introducción. Monographs in Systematic Botany from the Missouri Botanical Garden 97: 51-90.

Heilborn O (1925) Contributions to the ecology of the Ecuadorian páramos with special reference to cushion-plants and osmotic pressure. Svensk Botanisk Tidskrift 19(2): 153-170.

Hensold N (2008) Eriocaulaceae. In: Hokche O, Berry PE, Huber O (Eds) Nuevo Catálogo de la Flora Vascular de Venezuela. Fundación Instituto Botánico de Venezuela, Caracas, 735-741. 
Hensold N (2014) Eriocaulaceae. In: Jørgensen PM, Nee MH, Beck SG (Eds) Catálogo de las Plantas Vasculares de Bolivia. Monographs in Systematic Botany from the Missouri Botanical Garden 127: 581-583.

Hensold N, Hammel BE (2003) Eriocaulaceae. In: Hammel BE, Grayum MH, Herrera C, Zamora N (Eds) Manual de Plantas de Costa Rica, Vol. II. Monographs in Systematic Botany from the Missouri Botanical Garden 92: 569-575.

Huft MJ (1994) 261. Eriocaulaceae. In: Davidse G, Sousa Sánchez M, Chater AO (Eds) Flora Mesoamericana 6: 178-184.

IUCN Standards and Petitions Subcommittee (2014) Guidelines for using the IUCN Red List Categories and Criteria. Version 11. Prepared by the Standards and Petitions Subcommittee. Downloaded from http://www.iucnredlist.org/documents/RedListGuidelines.pdf [on 20 July 2015]

Jørgensen PM, Ulloa Ulloa C, Madsen J, Valencia Reyes R (1995) A floristic analysis of the high Andes of Ecuador. In: Churchill S, Balslev H, Forero E, Luteyn JL (Eds) Biodiversity and Conservation of Neotropical Montane Forests. New York Botanical Garden, Bronx NY, 221-237.

JSTOR (2000 onwards) Global plants database. Accessed at http://plants.jstor.org/search [various dates, 2014]

Körnicke F (1863) Eriocaulaceae. In: Martius CFP (Ed.) Flora Brasiliensis 3(1/2). R. Oldenbourg, Munich \& Leipzig, 274-507. http://www.biodiversitylibrary.org/item/9652\#page/3/ mode/1up

Kunth KS (1816) Eriocauleae. In: Humboldt FWHA, Bonpland AJA, Kunth KS, Nova Genera et Species Plantarum (quarto ed.) Volume 1(3). Paris, 251-254. http://www.biodiversitylibrary.org/item/11233\#page/314/mode/1up

Kunth KS (1841) Eriocauleae. Enumeratio Plantarum 3. J. G. Cottae, Stuttgart, 492-580. http://bibdigital.rjb.csic.es/ing/Libro.php?Libro=1759

León-Yánez S, Hensold N (1999) Eriocaulaceae. In: Jørgensen PM, León-Yánez S (Eds) Catalogue of the Vascular Plants of Ecuador. Monographs in Systematic Botany from the Missouri Botanical Garden 75: 454.

Levitt J (1956) The Hardiness of Plants. Academic Press, New York, 278 pp.

Lozano P, Cleef AM, Bussmann RW (2009) Phytogeography of the vascular páramo flora of Podocarpus National Park, south Ecuador. Arnaldoa 16(2): 69-85. http://www.biodiversitylibrary.org/item/125577\#page/209/mode/1up

Luteyn JL (1999) Páramos: a checklist of plant diversity, geographical distribution and botanical literature. Memoirs of the New York Botanical Garden 84: 1-278.

Madrinán S, Zapata F (2001) Flora Ilustrada del Páramo de Chingaza, Colombia. Laboratorio de Botánica \& Sistemática, Universidad de los Andes, Bogotá. https://chingaza.uniandes. edu.co/FIC/ [on 8 June 2014]

McCully ME, Canny MJ, Huang CX (2004) The management of extracellular ice by petioles of frost-resistant herbaceous plants. Annals of Botany 94: 665-674. doi: 10.1093/aob/ mch191

Melcher IM, Bouman F, Cleef AM (2004) Seed atlas of the monocotyledonous genera of the páramo. Flora 199: 286-308. doi: 10.1078/0367-2530-00157 
Moldenke HN (1952) Additional notes on the Eriocaulaceae VIII. Phytologia 4: 134-152. doi: 10.5962/bhl.part.18068

Moldenke HN (1953) Additional notes on the Eriocaulaceae. IX. Phytologia 4: 200-208. http://www.biodiversitylibrary.org/item/47070\#page/216/mode/1up

Moldenke HN (1975a) Additional notes on the Eriocaulaceae. LIII. Phytologia 30: 16-62. http://www.biodiversitylibrary.org/item/48964\#page/24/mode/1up

Moldenke HN (1975b) Annotated notes on the Eriocaulaceae. LIV. Phytologia 30: 71-125. http://www.biodiversitylibrary.org/item/48964\#page/81/mode/1 up

Moldenke HN (1975c) Additional notes on the Eriocaulaceae. LV. Phytologia 30: 251-280. http://www.biodiversitylibrary.org/item/48964\#page/265/mode/1 up

Moldenke HN (1976) Additional notes on the Eriocaulaceae. LIX. Phytologia 33: 9-58. doi: 10.5962/bhl.part.16779

Moldenke HN (1979) Additional notes on the Eriocaulaceae. LXXXIII. Phytologia 42: 29-44. http://www.biodiversitylibrary.org/item/46978\#page/37/mode/1 up

Moldenke HN (1983) Additional notes on the Eriocaulaceae. XCIV. Phytologia 54: 434-459. doi: 10.5962/bhl.part.14430

Moscol Olivera MC, Cleef AM (2009) A phytosociologial study of the páramo along two altitudinal transects in El Carchi province, northern Ecuador. Phytocoenologia 39: 79-107. doi: 10.1127/0340-269X/2009/0039-0079

Oriani A, Sano PT, Scatena VL (2009) Pollination biology of Syngonanthus elegans (Eriocaulaceae - Poales). Australian Journal of Botany 57: 94-105. doi: 10.1071/BT08119

Parsons RF, Gibson N (2009) The cushion plants of lowland southern Australia. Cunninghamia 11(2): 177-184.

Pedraza-Peñalosa P, Betancur J, Franco-Rosselli P (2005) Chisacá, un recorrido por los páramos andinos. $2^{\text {nd }}$ ed. Instituto de Ciencias Naturales e Instituto de Investigación de Recursos Biológicos Alexander von Humboldt. Bogotá, 340 pp. http://www.researchgate.net/publication/266328313_CHISAC_UN_RECORRIDO_POR_LOS_PRAMOS_ANDINOS

Rangel-Ch. JO (2000) Clima de la Región Paramuna en Colombia. In: Rangel-Ch. JO (Ed.) Colombia Diversidad Biotica III. Región de vida paramuna de Colombia. Inst. Cienc. Nat., Univ. Nac. de Colomba / Inst. Alexander von Humboldt, Bogotá, 85-125.

Rangel-Ch. JO, Ariza-NC (2000) La vegetación del Parque Nacional Natural Chingaza. In: Rangel-Ch. JO (Ed.) Colombia Diversidad Biotica III. Región de vida paramuna de Colombia. Inst. Cienc. Nat., Univ. Nac. de Colomba / Inst. Alexander von Humboldt, Bogotá, 722-755.

Rangel-Ch. JO, Lowy-CP, Aguilar-PM, Garzón-C A (1997) Tipos de vegetación en Colombia. In: Rangel-Ch. JO (Ed.) Colombia Diversidad Biótica II. Instituto de Ciencias NaturalesIDEAM. Bogotá, 89-367.

Rangel-Ch. JO, Sánchez D (2005) La flora del páramo de Frontino. In: van der Hammen T, Rangel-Ch. JO, Cleef AM (Eds) Studies on Tropical Andean Ecosystems 6. Gebrüder Bornträger, Berlin, Stuttgart, 833-857.

Rauh W (1939) Über polsterförmigen Wuchs: ein Beitrag zur Kenntnis der Wuchsformen der höheren Pflanzen. Nova Acta Leopoldina, n.F., Bd 7(49): 267-508. 
Rivera-Diaz O (2010) Caracterización floristica de la alta montaña de Perijá. In: Rangel-Ch. JO (Ed.) Colombia Diversidad Biotica V. La alta montańa de la Serranía de Perijá. Instituto de Ciencias Naturales, Bogotá, 71-132.

Rosa MM, Scatena VL (2007) Floral Anatomy of Paepalanthoideae (Eriocaulaceae, Poales) and their Nectariferous Structures. Annals of Botany 99: 131-139. doi: 10.1093/aob/mcl231

Ruhland W (1903) Eriocaulaceae. In: Engler A (Ed.) Das Pflanzenreich IV. 30 (Heft 13): 1-294. Wilhelm Engelmann, Leipzig. http://www.biodiversitylibrary.org/item/68177\#page/7/ mode/1up

Ruiz H (1940) Travels of Ruíz, Pavón, and Dombey in Peru and Chile (1777-1778). Dahlgren BE, translator. Publications of the Field Museum of Natural History, Botanical series 21 : 1-372. http://www.biodiversitylibrary.org/item/19741\#page/7/mode/1 up

Santa Cruz L (2011) Flora de espermatofitas del distrito de Pulán, Santa Cruz, Cajamarca. MS Thesis, Univ. Nac. Mayor de San Marcos, Lima, Peru.

Schmidt-Mumm U, Vargas-Ríos O (2012) Comunidades vegetales de las transiciones terrestreacuáticas del páramo de Chingaza, Colombia. Revista de Biología Tropical. / International Journal of Tropical Biology 60(1): 35-64. http://ref.scielo.org/m8v9h8

Standley PC (1937) Eriocaulaceae. In: Flora of Costa Rica, Publications of the Field Museum of Natural History, Botanical Series 18(1): 147-148. http://www.biodiversitylibrary.org/ item/19722\#page/157/mode/1up

Stauffer FW, Stauffer J, Dorr LJ (2012) Bonpland and Humboldt specimens, field notes, and herbaria; new insights from a study of the monocotyledons collected in Venezuela. Candollea 67(1): 75-130. doi: 10.15553/c2012v671a10

Stützel T (1984) Blüten- und infloreszenzenmorphologische Untersuchungen zur Systematik der Eriocaulaceen. Dissertationes botanicae 71. J. Cramer, Vaduz, 108 pp.

Stützel T, Gansser N (1996) Floral morphology of North American Eriocaulaceae and its taxonomic implications. Feddes Repertorium 106: 495-502. doi: 10.1002/fedr.19961060518

Suessenguth K (1942) Neue pflanzen aus Costa Rica, insbesondere vom Chirripó. Grande. Botanische Jahrbücher für Systematik 72(2): 270-302.

The Plant List (2013) Version 1.1. Published on the Internet; http:/www.theplantlist.org/ [accessed 30 Jan 2016]

Thiers B (2015 and continuously updated) Index Herbariorum: A global directory of public herbaria and associated staff. New York Botanical Garden's Virtual Herbarium. http:// sweetgum.nybg.org/ih/

Tissot-Squalli ML (1997) Monographische Bearbeitung von Paepalanthus subgenus Platycaulon. Dissertationes Botanicae Band 280. J. Cramer, Berlin, 242 pp.

Tropicos (Botanical information system at the Missouri Botanical Garden) 2015. Specimen records of Eriocaulon microcephalum Kunth. http://www.tropicos.org/Name/12400353 [accessed 13 Oct 2015]

Trovó M, Stützel T (2011) Diaspores in Eriocaulaceae: morphology, mechanisms and implications. Feddes Repertorium 122(7-8): 456-464. doi: 10.1002/fedr.201200003

Trovó M., Andrade MJG, Sano PT, Ribeiro PL, van den Berg C (2013) Molecular phylogenetics and biogeography of Neotropical Paepalanthoideae with emphasis on Brazilian 
Paepalanthus (Eriocaulaceae). Botanical Journal of the Linnean Society 171(1): 225-243. doi: $10.1111 /$ j.1095-8339.2012.01310.x

Vareschi V (1970) Flora de los Páramos de Venezuela. Universidad de los Andes, Merida, 429 pp. Vargas O, Rivera D (1991) Comunidades vegetales del Parque Nacional Natural Chingaza: Sector I Rio La Playa - Rio Guatiquía, (resultados preliminares). Cuadernos Divulgativos No. 23. Facultad de Ciencias, Universidad Javeriana, Bogotá, 74 pp.

Weberbauer A (1945) El Mundo Vegetal de los Andes Peruanos. Ministerio de Agricultura, Lima, 722 pp. http://bibdigital.rjb.csic.es/ing/Libro.php?Libro=48

Weigend M (2002) Observations on the biogeography of the Amotape-Huancabamba Zone in Northern Peru. Botanical Review 68(1): 38-54. doi: 10.1663/0006-8101(2002)068[003 8:OOTBOT]2.0.CO;2

Weigend M (2004) Additional observations on the biogeography of the Amotape-Huancabamba zone in Northern Peru: defining the south-eastern limits. Revista Peruana de Biología 11(2): 127-134. doi: 10.15381/rpb.v11i2.2447

Young KR, Cano A (1994) Aporte florístico de la puna del Parque Nacional del Manu. Boletín de Lima 16(91-96): 381-393.

Young KR, León B (1988) Vegetación de la zona alta del Parque Nacional Río Abiseo, San Martín. Revista Forestal del Perú 15: 3-20. 


\section{Supplementary material I}

\section{Paepalanthus pilosus complex, exsiccatae list}

Authors: Nancy Hensold

Data type: Text file

Copyright notice: This dataset is made available under the Open Database License (http://opendatacommons.org/licenses/odbl/1.0/). The Open Database License $(\mathrm{ODbL})$ is a license agreement intended to allow users to freely share, modify, and use this Dataset while maintaining this same freedom for others, provided that the original source and author(s) are credited.

\section{Supplementary material 2}

\section{Paepalanthus pilosus complex, specimen database}

Authors: Nancy Hensold

Data type: Excel spreadsheet. List of examined specimens and geo-references of the localities

Explanation note: Contains complete label information of all examined specimens, as well as estimated geographic coordinates (in decimal degrees) for all specimens.

Copyright notice: This dataset is made available under the Open Database License (http://opendatacommons.org/licenses/odbl/1.0/). The Open Database License $(\mathrm{ODbL})$ is a license agreement intended to allow users to freely share, modify, and use this Dataset while maintaining this same freedom for others, provided that the original source and author(s) are credited. 